\title{
Liquid and Gaseous Waste Operations Section Annual Operating Report CY 1998
}

RECEIVED

MAR 161999

OS TI

J. J. Maddox

C. B. Scott

WAMGED MO OPERATEO BY

1OCKHEED MARTN ENERGY RESEARCH CORPORATON FCA THE ULUTEO STATES DEPARTUENT OF ENERGY 
This report has been reproduced from the best available copy.

Reports are available to the public from the following source.

National Technical Information Service

5285 Port Royal Road

Springfield, VA 22161

Telephone 703-605-6000 (1-800-553-6847)

TDD 703-487-4639

Fax 703-605-6900

E-mail orders ntis.fedworld.gov

Web site http://www.ntis.gov/ordering.htm

Reports are available to U.S. Department of Energy (DOE) employees, DOE contractors, Energy Technology Data Exchange (ETDE) representatives, and International Nuclear Information System (INIS) representatives from the following source.

Office of Scientific and Technical Information

P.O. Box 62

Oak Ridge, TN 37831

Telephone 423-576-8401

Fax 423-576-5728

E-mail reports adonis.osti.gov

Web site http:/www.osti.gov/products/sources.html

Reports produced after January 1, 1996, are generally available via the DOE Information Bridge. Web site http://www.doe.gov/bridge 


\section{DISCLAIMER}

This report was prepared as an account of work sponsored by an agency of the United States Government. Neither the United States Government nor any agency thereof, nor any of their employees, make any warranty, express or implied, or assumes any legal liability or responsibility for the accuracy, completeness, or usefulness of any information, apparatus, product, or process disclosed, or represents that its use would not infringe privately owned rights. Reference herein to any specific commercial product, process, or service by trade name, trademark, manufacturer, or otherwise does not necessarily constitute or imply its endorsement, recommendation, or favoring by the United States Government or any agency thereof. The views and opinions of authors expressed herein do not necessarily state or reflect those of the United States Government or any agency thereof. 


\section{DISCLAIMER}

Portions of this document may be illegible in electronic image products. Images are produced from the best available original document. 


\title{
LIQUID AND GASEOUS WASTE OPERATIONS SECTION
}

\section{ANNUAL OPERATING REPORT}

\section{CY 1998}

Date Published: January 1999

\author{
J. J. Maddox \\ C. B. Scott
}

\author{
Prepared for the \\ U.S. Department of Energy \\ Office of Environmental Management \\ Bechtel Jacobs Company LLC \\ managing the \\ Environmental Management Activities at the \\ Oak Ridge Y-12 Plant Oak Ridge National Laboratory \\ Paducah Gaseous Diffusion Plant Portsmouth Gaseous Diffusion Plant \\ under contract DE-AC05-98OR22700 \\ for the \\ U.S. Department of Energy
}




\section{TABLE OF CONTENTS}

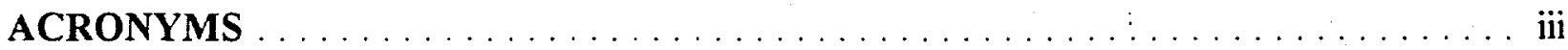

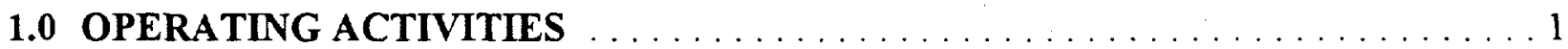

1.1 PROCESS WASTE SYSTEM $\ldots \ldots \ldots \ldots \ldots \ldots \ldots \ldots \ldots \ldots \ldots$

1.2 LIQUID LOW-LEVEL WASTE $($ LLLW) SYSTEM $\ldots \ldots \ldots \ldots \ldots \ldots \ldots \ldots$

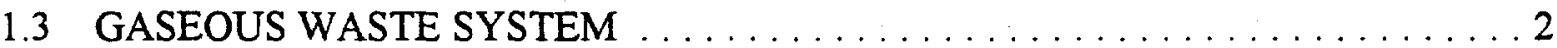

2.0 UPGRADE AND SPECIAL PROJECT ACTIVITIES $\ldots \ldots \ldots \ldots \ldots \ldots$

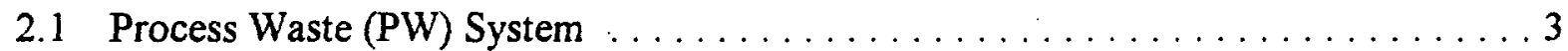

2.1.1 Reengineering Activities for Process Waste Treatment . . . . . . . . . 3

2.1 .2 Miscellaneous . . . . . . . . . . . . . . . . . . . . . . 4

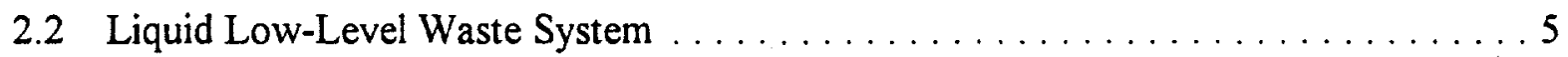

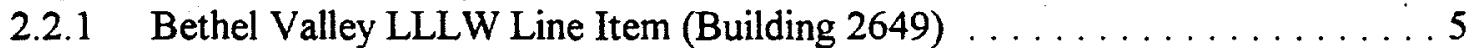

2.2.2 Bethel Valley LLLW Line Item (Building 3025E) $\ldots \ldots \ldots \ldots \ldots \ldots \ldots$

2.2.3 Federal Facility Agreement Line Item $\ldots \ldots \ldots \ldots \ldots \ldots$

(Hot Off-Gas (HOG) Pot Upgrades)

2.2.4 Bethel Valley Federal Facility Agreement Line Item (Buildings 2537 . . . 9 and 2568)

2.2.5 Melton Valley Storage Tanks Capacity Increase Line Item . . . . . . . . 11 (Building 7856)

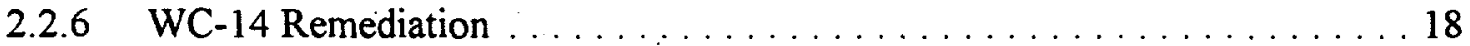

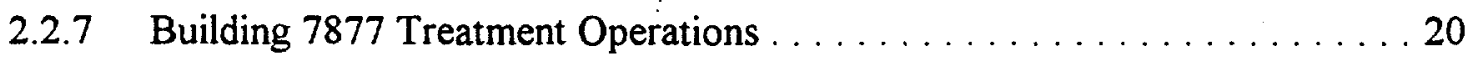

2.2.8 Sludge Mobilization Demonstration $\ldots \ldots \ldots \ldots \ldots \ldots \ldots \ldots \ldots \ldots$

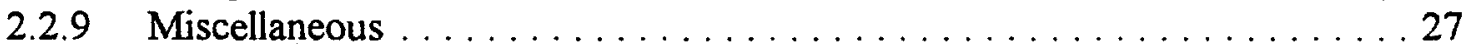

2.3 WOCC Data Acquisition System (DAS) and Distributed Control System (DCS) . . 28

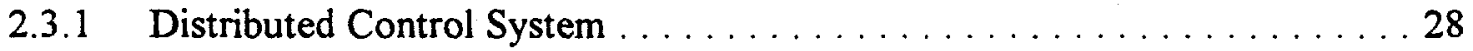

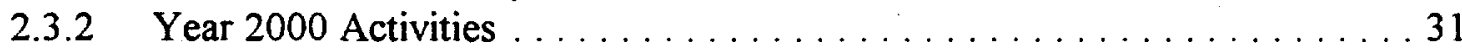

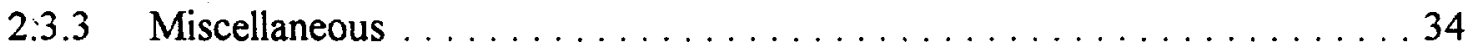

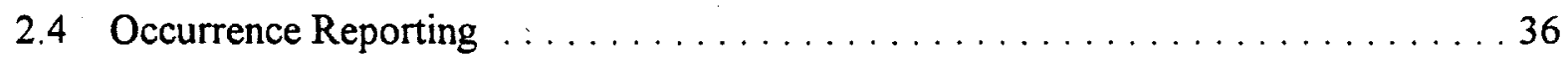

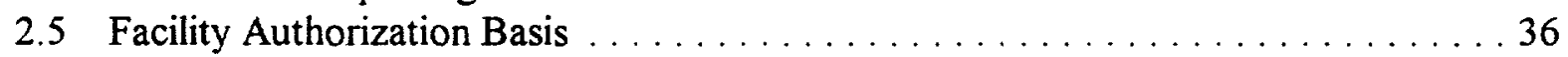

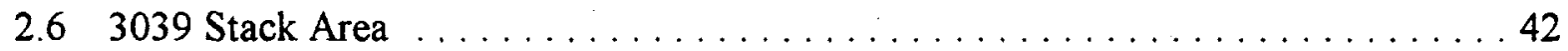

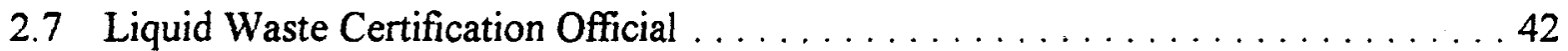

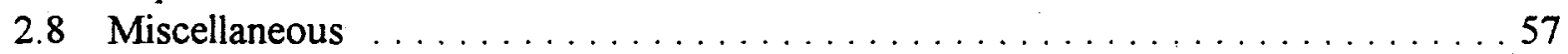

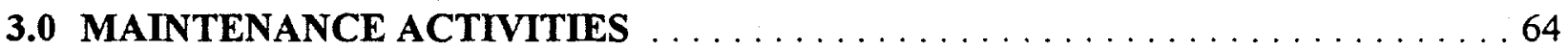

3.1 Process Waste Treatment Complex (Buildings 3544 and 3608) and Collection . . . 64 System

3.2 Liquid Low-Level Waste System . . . . . . . . . . . . . . . . . . . 69

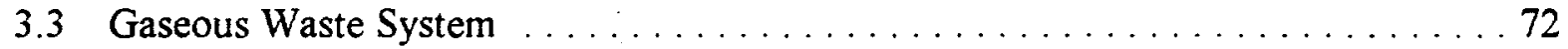




\section{TABLE OF CONTENTS (continued)}

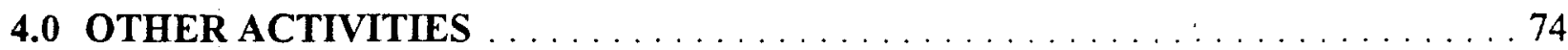

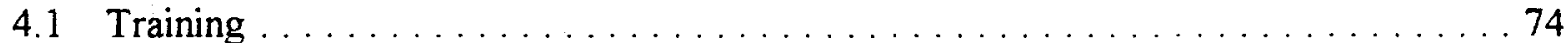

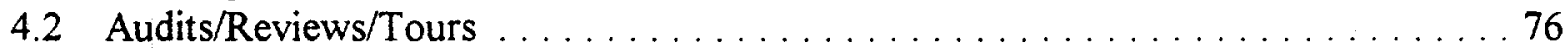

4.3 Environmental Restoration Support Activities . . . . . . . . . . . . . . 78

4.4 Federal Facility Agreement for the LLLW System Activities $\ldots \ldots \ldots \ldots \ldots$

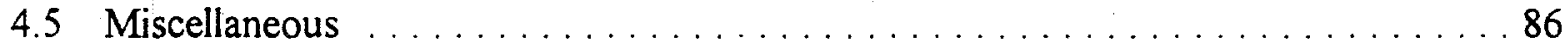

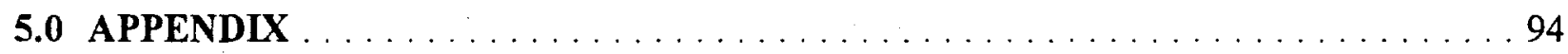

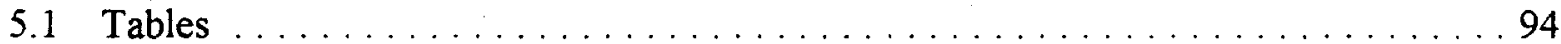

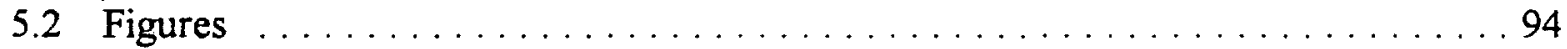




\section{ACRONYMS}

\begin{tabular}{ll} 
BJC & Bechtel-Jacobs Company \\
CERCLA & Comprehensive Environmental Response, Compensation, and Liability Act \\
DAS & Data Acquisition System \\
DCS & Distributed Control System \\
DF & Decontamination Factors \\
DOE & Department of Energy \\
EC & Environmental Compliance \\
FAB & Facility Authorization Basis \\
FFA & Federal Facility Agreement \\
FPSC & Fixed Price Subcontractor \\
GI & Generator Interface \\
GIE & Generator Interface Equivalent \\
HEPA & High Efficiency Particulate Air \\
HFIR & High Flux Isotope Reactor \\
HOG & Hot Off-Gas \\
HVAC & Heating, Ventilation, and Air Conditioning \\
HWOG & Hazardous Waste Operations Group \\
I\&C & Instrumentation and Controls \\
LFABB & Laboratory Facility Authorization Basis Board \\
LGCO & Laboratory Generator Characterization Official \\
LGWO & Liquid and Gaseous Waste Operations \\
LI & Line Item \\
LLLW & Liquid Low-Level Waste \\
LMER & Lockheed Martin Energy Research \\
MOU & Memorandum of Understanding \\
MV & Melton Valley \\
MVST & Melton Valley Storage Tanks \\
NPDES & National Pollution Discharge Elimination System \\
NTS & Nevada Test Site \\
ORNL & Oak Ridge National Laboratory \\
ORO & Oak Ridge Operations \\
OSR & Operating Safety Requirements \\
OTE & Out-of-Tank Evaporation \\
P\&E & Plant and Equipment \\
PCB & Polychlorinated Biphenyl \\
PLC & Programmable Logic Controller \\
PWTC & Process Waste Treatment Complex \\
QE\&I & Quality Engineering and Inspections \\
RA & Readiness Assessment \\
RSA & Readiness Self-assessment \\
SAR & Safety Analysis Report \\
& \\
\hline
\end{tabular}




\section{ACRONYMS (continued)}

$\begin{array}{ll}\text { STP } & \text { Sewage Treatment Plant } \\ \text { SWSA } & \text { Solid Waste Storage } \\ \text { TDEC } & \text { Tennessee Department of Environment and Conservation } \\ \text { TRU } & \text { Transuranic } \\ \text { TSCA } & \text { Toxic Substance Control Act } \\ \text { TSR } & \text { Technical Safety Requirements } \\ \text { TWRF } & \text { Transported Waste Receiving Facility } \\ \text { USQD } & \text { Unreviewed Safety Question Determination } \\ \text { VB } & \text { Valve Box } \\ \text { VR } & \text { Variance Request } \\ \text { WAC } & \text { Waste Acceptance Criteria } \\ \text { WCO } & \text { Waste Certification Official } \\ \text { WOCC } & \text { Waste Operations Control Center } \\ \text { WMOD } & \text { Waste Management Operations Division }\end{array}$




\section{LIQUID AND GASEOUS WASTE OPERATIONS (LGWO) SYSTEM \\ ANNUAL OPERATING REPORT \\ CY1998}

\subsection{OPERATING ACTIVITIES}

\subsection{Process Waste System}

A total of $6.85 \times 10^{7}$ gallons (gal) of liquid waste was decontaminated by the Process Waste Treatment Complex - Building 3544 ion exchange system during calendar year (CY) 1998. This averaged to $130 \mathrm{gpm}$ throughout the year. During the year, the regeneration of the ion exchange resins resulted in the generation of $1.65 \times 10^{3}$ gal of Liquid Low-Level Waste (LLLW). See Table 1 for a monthly summary of activities at Building 3544. Figure 1 shows a diagram of the Process Waste Collection and Transfer System and Figure 2 shows a diagram of the Building 3544 treatment process. Figures 3,45 , and 6 show a comparison of operations at Building 3544 in 1997 with previous years. Figure 7 shows a comparison of annual rainfall at Oak Ridge National Laboratory (ORNL) since 1992.

A total of $1.88 \times 10^{8}$ gal of liquid waste (average of $357 \mathrm{gpm}$ throughout the year) was treated at the Process Waste Treatment Complex - Building 3608. Of this amount, $2.01 \times 10^{7} \mathrm{gal}$ was treated by the precipitation/clarification process for removal of heavy metals. Fiftyseven boxes $\left(5.47 \times 10^{3} \mathrm{ft}^{3}\right)$ of solid sludge generated by the precipitation/clarification process were removed from the filter press room. Building 3608 receives wastewater from Building 3544 , the metals/nonmetals pumping station (collects wastewater from the 1505 and 2000 areas), the 190 pumping station (collects wastewater from the 4500 complex area), and the Melton Valley (MV) process waste collection tanks. Building 3608 removes particulates, heavy metals, and organics, as well as adjusts the $\mathrm{pH}$ of the wastewater, before discharge to White Oak Creek. In addition, the softening process (precipitation/clarification) for water requiring radiological treatment at Building 3544 is located at this facility. See Table 2 for a monthly summary of activities at Building 3608 . Figure 8 shows a diagram of the Building 3608 treatment process. Figures 9 and 10 show a comparison of operations at Building 3608 in 1997 with previous years.

\subsection{LIQUID LOW-LEVEL WASTE (LLLW) SYSTEM}

The $\mathrm{A} 2$ and $2 \mathrm{~A} 2$ evaporator systems operated normally during the year. A total of $1.74 \times 10^{5}$ gal of LLLW was processed through the A2 evaporator system and $3.27 \times 10^{5}$ gal of LLLW was processed through the $2 \mathrm{~A} 2$ evaporator system. There was $5.91 \times 10^{3}$ gal of concentrate transferred from the $\mathrm{A} 2$ system and $10.55 \times 10^{3}$ gal concentrate transferred from the $2 \mathrm{~A} 2$ system to the waste storage tanks. Figure 11 shows a diagram of the LLLW Collection and Transfer System. See Table 3 for a monthly summary of activities at the evaporator systems. Figure 12 shows a graphical representation of the amount of concentrate presently stored at ORNL awaiting disposal. See Figure 13 (for a graphical comparison of the generation of 
LLLW at ORNL over the last five years) and Figures 14 through 28 for a comparison of the generation of LLLW by individual sources over the last five years.

\subsection{GASEOUS WASTE SYSTEM}

The gaseous waste system operated normally during the reporting period. Normal operations means that continuous ventilation service was provided to all customer facilities except during scheduled maintenance periods. A schematic of the Gaseous Waste System is shown in Figure 29. 
Several upgrade activities were underway during the year. Because many of the upgrades were to existing Liquid and Gaseous Waste Operations (LGWO) operating facilities, coordination between LGWO and construction personnel was a priority; with several LGWO technical staff personnel being involved in daily planning of construction coordination activities. The Melton Valley Storage Tanks Capacity Increase Project, which provided an additional 550,000 gallons of usable storage space for LLLW concentrate, was placed in service by the December $4^{\text {th }}$ milestone date after undergoing a thorough Readiness Assessment by Department of Energy - Oak Ridge Operations (DOE-ORO) personnel. Personnel also completed construction of the new above-ground filter pit for the LLLW Evaporator Facility as part of the Bethel Valley Federal Facility Agreement (FFA) Line Item project. Descriptions of the various activities are given in the following sections, with a month by month description of activities immediately following the project description.

Personnel continued efforts to maintain LGWO procedures as up-to-date, usable documents. Fourty-five revisions were approved and issued during the year to existing LGWO procedures. Two new procedures were issued and four procedures were canceled. Seven document change directives were issued for LGWO procedures and an additional three procedures underwent their scheduled two-year review but did not require any revisions. Nineteen revisions were issued for LGWO administrative guides and conduct of operations guides.

\subsection{Process Waste (PW) System}

\subsubsection{Reengineering Activities for Process Waste Treatment}

A proposal to add zeolite columns and allow for the treatment of process wastewater at Building 3608 , thus eliminating the currently used operation at Building 3544 , was evaluated as part of the WMRAD Reengineering effort looking for increased efficiency and cost savings. The activity was ended during the year with no funding source for the upgrades being identified.

\section{$\underline{\text { January }}$}

Attended a "dry-run" presentation of the upgrades being discussed for the addition of zeolites at building 3608 and provided information to personnel who will make the presentation to DOE-ORO personnel. The dry-run was in preparation for a presentation to DOE and other Lockheed Martin personnel. Pending their approval, funding would hopefully be provided to further investigate and continue with the preliminary design of this upgrade. Also reviewed a cost estimate and provided comments for a proposed upgrade to the water treatment process at Building 3608 . 


\section{February}

Reviewed and commented on a feasibility study in support of this reengineering effort. Participated in a walk through of the planned reengineering effort with Engineering and Bechtel-Jacobs (BJ) personnel. The purpose of the walk through was primarily to get the Bechtel-Jacobs personnel familiar with the system so they could determine how best to approach their review of the proposed upgrade at Building 3608 .

\section{March}

Met with personnel from Engineering and from Jacobs Engineering to help them gather enough information to evaluate whether it is most cost effective to decontaminate and decommission Building 3544 (after the upgrade to Building 3608 which would eliminate the need for operations at 3544) or to place the building in a shutdown mode and maintain it as such. Also attended a meeting to address some unresolved issues relating to the reengineering.

\section{April}

Participated in a presentation to DOE and to Bechtel Jacobs Corporation personnel of the planned upgrade of the Process Waste Treatment Complex. The presentation was a continuation of efforts to provide information in order to assure acceptance of the concept. Hopefully this will be used to gain needed funding as the project progresses. It was agreed that activities were far enough along in the project to present it to the Tennessee Department of Environment and Conservation (TDEC).

\subsubsection{Miscellaneous}

\section{$\underline{\text { April }}$}

Installed an overflow line from tank F-1060 to F-1070 at the Process Waste Treatment Complex - Building 3608 as a precautionary measure to prevent overflow of the small F-1060 tank to the diked containment area at the facility.

Assisted personnel from Jacobs Engineering in their evaluation of treatment alternatives for CERCLA related wastewaters at ORNL.

Assisted Chem Tech personnel in an evaluation of sludge generation from the Process Waste system. 
June

Reviewed a document, and provided comments, to Chemical Technology personnel on a document which describes the testing of the F-1006 Clarifier System Upgrade at Building 3608 .

Provided support to Engineering personnel in the development of specifications for a Request for Proposal for the pond remediation project.

\subsection{Liquid Low-Level Waste System}

2.2.1 Bethel Valley LLLW Line Item (Building 2649)

The Transported Waste Receiving Facility (TWRF, Building 2649) which provides a doublecontained facility to empty transported LLLW waste containers (both tankers and LLLW bottle packages) to a new collection tank, and also provided a new transfer system to the LLLW Central Waste Collection Header, was declared operational in early January after undergoing the Lockheed Martin Energy Research (LMER) and DOE-ORO readiness review process throughout the year. Building 2649 was constructed to provide a facility for unloading transported LLLW packages that meets the requirements of the FFA for the LLLW System.

January

Received authorization to start operation of the Transported Waste Receiving Facility (Building 2649). This closes the DOE-ORO Operational Readiness Review. The Transported Waste Receiving Facility will provide a facility to unload transported waste at ORNL that meets requirements of the FFA for the LLLW System.

\subsubsection{Bethel Valley LLLW Line Item (Building 3025E)}

Completed construction of the Building 3025E upgrades during the year. This phase of the project installed a new collection tank and drain system for Building 3025E that is operated by Building 3025E personnel. A new double-contained transfer line from the collection tank was also installed to Valve Box 1A so that the LLLW could be transferred to the Central Waste Collection Header in a system that meets requirements of the FFA for the LLLW System.

January

Continued construction activities by the fixed price subcontractor for the Building $3025 \mathrm{E}$ upgrade portion of the Bethel Valley LLLW CAT Line Item Project. Installation of the north to south run of piping to Valve Box $1 \mathrm{~A}$ from Hillside was started. Continued installation of 
the duct work from the new collection tank to the High Efficiency Particulate Air (HEPA) filters. The installation of the piping section into Valve Box $1 \mathrm{~A}$ was performed after the penetration was placed in the east wall of the valve box. A blank flange/pancake was installed in the pipe to prevent the introduction of liquid through this connection until the system is operational. The pancake was just down stream of the new isolation valve located inside valve box. Final connections at the Valve box would not be made until all test and checkout activities as well as the required readiness determinations had been performed. Activities to ensure that the piping connections into Valve Box 1A are leak tight were initiated. The piping run from Building $3025 \mathrm{E}$ was not complete. The concrete wall in the basement of $3025 \mathrm{E}$ was placed.

\section{February}

Continued construction activities by the fixed price subcontractor. Continued installation of LLLW piping inside Building 3025E. Installation of the electrical panel in the filter areas was completed. Installation of cell ventilation piping on the outside of Building $3025 \mathrm{E}$ was completed to the building's stack header. Installation of tubing and electrical wiring in the filter area continued. Resumed installation of cathodic protection components. Repair/restoration of the curbing, sidewalk and roadway (where possible) was started. At the end of the month a meeting was held with MK Ferguson, Engineering, Waste Operations, and Metal \& Ceramics Division personnel to discuss the logistics of the remaining tie-ins. The discussions dealt with how the tie-ins were to be made in addition to the preliminary requirements which have to be satisfied before tie-ins can be started.

\section{$\underline{\text { March }}$}

Continued construction activities by the fixed price subcontractor. Continued installation of LLLW piping inside Building 3025E. Completed pressure/vacuum testing of new cell ventilation duct downstream of the HEPA filters. Installation of tubing and electrical wiring in the filter area continued. Conducted a walk-down of the work completed to date in the filter area and inside the building. Closure of the excavation next to Valve Box 1A was completed. Restoration of the curbing and street to preconstruction condition was on-going.

\section{April}

Continued construction activities by the fixed price subcontractor. Wrapped insulation around the new cell ventilation duct downstream of the HEPA filters. Completed installation of tubing and electrical wiring in the filter area. Worked to address the punchlist items resulting from the walk-down of the work completed to date in the filter area and inside the building. Replaced the asphalt on Hillside Avenue. Issued draft Readiness Self-Assessment (RSA) Plan and readiness tree to the RSA team. Revised the plan and readiness plan based on comments from the RSA team. 
$\underline{\text { Mav }}$

Continued construction activities by the fixed price subcontractor. Continued efforts to complete the punchlist items resulting from the walk-down of the work completed to date in the filter area and inside Building 3025E. A review of the constructions site showed that several punchlist items remains. The punchlist did not include items which had been procured but not received. Delivery was expected during late May and early June. Continued RSA team activities.

$\underline{\text { June }}$

Continued construction activities by the fixed price subcontractor. Continued efforts to complete the punch list items resulting from the walk-down of the work completed to date in the filter area and inside Building 3025E. Continued RSA team activities. Accepted delivery of the heat detectors which would be placed in the cell ventilation piping. Completed connection of the new cell ventilation duct to the cell ventilation header. A pancake was installed in the flange at the connection point to the cell ventilation header to facilitate the installation of heat detectors.

$\underline{\text { July }}$

Continued construction activities by the fixed price subcontractor. Completed connection of the new cell ventilation duct to the cell ventilation header. A pancake was installed in the flange at the connection point to the cell ventilation header to facilitate the installation of heat detectors, which was completed the next week. Installation of the damper was completed. Test and balance for the ventilation system was completed. Removed the blank flange/pancake from the LLLW pipe inside Valve Box 1A. Performed the flow test of the piping between the new collection tank and VB-1A. The isolation valve inside of VB1A was locked out to prevent the introduction of liquid through this connection until the system is operational. Conducted the LLLW system tests of the new collection system. A few punch list items resulted from the system test. Continued RSA team activities.

\section{$\underline{\text { August }}$}

Continued progress by MK-Ferguson on correcting items found during testing. Several meetings were held with MK-Ferguson, Engineering, Waste Operations, and Metal \& Ceramics Division personnel to discuss the logistics of the final tie-ins. The discussions dealt with how the tie-ins were to be made in addition to the preliminary requirements which have to be satisfied before tie-ins can be started. The tie-ins would be made after the RSA requirements were met. Continued RSA team activities. 


\section{September}

Completed correcting items found during testing. Completed reworking of the piping downstream of the $\mathrm{pH}$ probe. Completed reworking of the piping downstream of the $\mathrm{pH}$ probe. The RSA team issued its final report. The RSA team concluded that readiness to begin operations of upgraded LLLW collection system for $3025 \mathrm{E}$ has been achieved. The final tie-ins of the hot drains to the new collection system were initiated this month. Removal of existing drain piping and connection to the newly installed LLLW piping is underway.

\section{October}

Completed correcting items found during testing. Completed the final tie-ins of the hot drains to the new collection system. Removal of existing drain piping was completed. Nondestructive examination of the tie-in welds was completed. The final test for the hot cell tie in welds was successfully completed on October 27. No leaks were discovered by the Quality Engineering and Inspections (QE\&I) inspector. The contents of the tank and drain piping system were pumped to VB-1A. No additional tests are required before the commencement of normal operations.

\subsubsection{Bethel Valley Federal Facility Agreement Line Item (Hot Off-Gas (HOG) Pot Upgrades)}

This phase of the line was completed in late December 1997 with the tie-in of the new HOG condensate collection tank to the off-gas duct. This project provided a new HOG condensate collection tank at the off-gas system's lowpoint in the 3500 area as well as a transfer system to the Process Waste Collection System so that the existing system, which was connected to the LLLW System, could be removed from service by the FFA Program. Sample analysis had shown that the condensate could be characterized as Process Waste. Activities during 1998 consisted of completion of punchlist items identified during startup.

\section{$\underline{\text { January }}$}

Continued efforts by the fixed price subcontractor to complete punch list items for the HOG pot portion of the Bethel Valley FFA Line Item Project. The final connection between the new collection tank and the existing HOG header was completed. Restoration of the curbing was on-going.

\section{April}

Repaved the roadway by the HOG Pot. The HOG Pot portion of the project rerouted condensate from the underground HOG ventilation system ductwork to the Process Waste System. 
Construction of a new above-ground cell ventilation and off-gas HEPA filter building (Building 2658) for the LLLW Evaporator Facility was completed. This allowed the existing below-grade pits which collect inleakage which must be treated as LLLW to be removed from service. It also provided a filter system that meets current inspection requirements for in-place testing of the filters.

$\underline{\text { January }}$

Continued construction activities by the fixed price subcontractor at the LLLW Evaporator Facility. Continued installation of electrical wiring within the control room. Instrumentation and control cabinets were placed in the control room. Installation of above ground duct piping was on-going. The filter housings were placed inside the enclosure. The delivery date for the repaired demisters slipped to the week of February 6, 1998. The manufacturer indicated that the repairs to the demisters were nearing completion.

\section{February}

Continued construction activities by the fixed price subcontractor at the LLLW Evaporator Facility. Installation of above ground duct piping continued. The duct heaters were set in place and wiring to the heaters was installed. Tubing installation was started. The manufacturer shipped the repaired demisters and they were installed after delivery to the site. A meeting was held to discuss the logistics of the final tie-ins. The discussions dealt with how the tie-ins were to be made in addition to the preliminary requirements which have to be satisfied before tie-ins can be started.

\section{$\underline{\text { March }}$}

Completed construction activities by the fixed price subcontractor at the LLLW Evaporator Facility. Installation and testing of tubing was completed. The replacement power panel was installed. Completed installation of the demisters. Excavations to allow for the test and balance of the cell vent duct work were made. Conducted a walk-down of the fire alarm and electrical systems in both 2531 and 2568 and the instrumentation tubing for 2568 in order to generate a punch list of remaining work for the fixed price subcontractor (FPSC). Provided input to the division's Task Work Authorization effort.

\section{April}

Continued construction activities by the fixed price subcontractor at the LLLW Evaporator Facility. Completed installation of the drain lines from the mist eliminators (demisters). Completed the pressure/vacuum testing of new cell ventilation duct downstream of the HEPA filters. Continued installation of the heat tracing. Completed re-work of the heat trace 
electrical power feed. Some test and check-out activities have been started, including the pressure testing of the LLLW piping. The excavations for the pipe testing locations were being filled in. Efforts to install temporary fans to allow flow testing of the newly installed piping was completed and began conducting flow tests of the newly installed piping. Continued efforts to complete the punchlist items resulting from the walk-down of the work completed to date. Issued draft RSA Plan and readiness tree to the RSA team and revised the plan and tree based on comments from the RSA team. Provided input to the division's Task Work Authorization effort.

\section{$\underline{\text { May }}$}

Continued construction activities by the fixed price subcontractor at the LLLW Evaporator Facility. Continued efforts to complete the punch list items resulting from the walk-down of the work completed to date. Continued RSA team activities. P\&E began field activities to connect the new ventilation duct piping to the existing system. The new duct system would remain isolated from the operating system until the completion of the RSA. P\&E completed excavation to expose $24^{\prime \prime}$ piping which were the initial tie-in points. $P \& E$ then completed installation of one of the 24 " piping sections. P\&E then completed installation of one of the 4" piping connections. P\&E also initiated a retrofit of the HEPA Filter housings.

June

Completed construction activities by the fixed price subcontractor at the LLLW Evaporator Facility. Continued RSA team activities. Connected the fire alarm system at Building 2568 . Plant and Equipment (P\&E) continued field activities to connect the new ventilation duct piping to the existing system. P\&E continued retrofitting of the HEPA Filter housings. The new duct system would remain isolated from the operating system until the completion of the RSA. The excavation and shoring for the next tie-in point was on-going.

$\underline{\text { July }}$

Continued RSA team activities. P\&E completed field activities to connect the new ventilation duct piping to the existing system. The excavation and shoring for the next tie-in point was completed. P\&E completed retrofitting of the HEPA Filter housings. The new duct system would remain isolated from the operating system until the completion of the RSA.

\section{$\underline{\text { August }}$}

Continued project activities. P\&E completed field activities to connect the new ventilation duct piping to the existing system. Excavation to uncover the final tie-in point was performed. Continued RSA team activities for the Bethel Valley FFA Line Item Project. Conducted a walk-down of the procedure for the operation of the new filter system and 
incorporated comments in the procedure. The new duct system would remain isolated from the operating system until the completion of the RSA.

\section{$\underline{\text { September }}$}

Continued project activities. The shoring for the final tie-in was installed. Connection of the cell vent and hot off-gas piping to the new filter system was nearly complete at the end of the month. Efforts to close out the remaining punchlist items was on-going. Continued RSA team activities for the Bethel Valley FFA Line Item Project. The new duct system would remain isolated from the operating system until the completion of the RSA.

\section{$\underline{\text { October }}$}

Continued project activities. Resolution of problems identified by the test and balance activity was nearing completion. RSA team activities for the Bethel Valley FFA Line Item Project are on-going. Retested and repaired the two cell ventilation filters that had failed DOP earlier. The cell ventilation system was then ready for operation. Verified the ability of the off-gas system to achieve the design flow. RSA team activities for the Bethel Valley FFA Line Item Project are on-going. The new duct system would remain isolated from the operating system until the completion of the RSA.

\section{November}

Continued project activities. Routed as-built drawings for signature. RSA team activities were on-going. Re-installation of cathodic protection system was completed. Recertification of the cathodic protection system was also completed and personnel were awaiting receipt of the report.

\section{December}

Placed the new aboveground off-gas and cell ventilation filter banks (Building 2568) in service after receiving approval from the RSA that was just completed. There was one poststart finding regarding cathodic protection. This project replaced two underground filter pits and upgraded the control room for the Evaporator Service Tanks. .

\subsubsection{Melton Valley Storage Tanks Capacity Increase Line Item (Building 7856)}

This line item provided LGWO with an additional 550,000 gallons of usable storage capacity for LLLW concentrate generated at the LLLW Evaporator Facility and from Environmental Restoration activities planned during the upcoming years. The six new 100,000 gallon tanks were built near the existing Melton Valley Storage Tanks (Building 7830). Activities during the year included the completion of construction, preoperational testing, and a successful Readiness Assessment by DOE-ORO personnel. Testing activities during the year required 
personnel to work 12 hour shifts due to delays in construction at the facility. This facility met the milestone date of December $4^{\text {th }}$ to be declared operational by DOE-ORO. This milestone was the primary identified activity for Bechtel Jacobs Waste Operations project activities at ORNL during the year.

$\underline{\text { January }}$

The Main Facility subcontractor continued with construction activities. Installation of the liner plate in the pump and valve vault was completed. All tank vault roof slabs had been completed. Concrete was placed for all of the pump and valve vault except for the blockouts for installation of the valve extensions and positive displacement pumps. Punchlist items for the mezzanine area were complete and all scaffolding was removed. The positive displacement pumps were set in place and the installation of piping, valves and supports continued in the pump and valve vault. Installation of heating, ventilation, and air conditioning (HVAC) equipment continued. Electrical work in the control room continued. Instrumentation cabinets and tubing work continued on the roof. The fixed-price subcontractor initiated a 58 hour work shift and a second 40 hour work shift in order to complete construction within the current contractual specifications. Work continued on Readiness Assessment activities in preparation for that activity.

\section{February}

The Main Facility subcontractor continued with construction activities. Installation of the liner plate in the pump and valve vault was completed. All tank vault roof slabs were completed. Concrete was placed for all of the pump and valve vault except for the blockouts for installation of the valve extensions. Punchlist items for the mezzanine area were completed and all scaffolding was removed. Cleanup of tank vaults 34-37 was completed, but work continued on vaults 32 and 33 . The positive displacement pumps were set in place and the installation of piping, valves and supports continued in the pump and valve vault. Installation of HVAC equipment continued. Electrical work in the control room continued. Instrumentation cabinets and tubing work continued on the roof. The FPSC continued with a 58 hour work shift and a second 40 hour work shift in an attempt to complete construction within the current contractual specifications. Work continued on Readiness Assessment activities. A meeting was held with DOE-ORO to address the graded approach process that is to be used and to identify the team members for the contractor independent team and the DOE team.

Construction and Engineering personnel entered the six tanks during the last week of February to remove construction debris and to obtain as-built information for the level instrumentation bubbler tube assemblies. Deflections of the bubbler tubes were identified during the entries and construction personnel were working at the end of the month to determine if the tubes could be repaired in-place or if replacement tubes would have to be installed. 
March

The Main Facility subcontractor continued with construction activities. Installation of the liner plate in the pump and valve vault is complete. All tank vault roof slabs have been completed. Concrete has been placed for all of the pump and valve vault except for the blockouts for installation of the valve extensions. Punchlist items for the mezzanine area are complete and all scaffolding has been removed. Installation of HVAC equipment and electrical work in the control room continues. Instrumentation cabinets and tubing work continues on the roof. Pipe supports in the pump and valve vault were submitted for preliminary acceptance inspection. Eleven of the forty-one inspected were found to meet construction specifications. The FPSC is continuing with two shifts in an attempt to complete construction. The forecast for completion by the fixed price subcontractor was April $30^{\text {th }}$. The forecast for completion of MK-Ferguson direct hire work was June $15^{\text {th }}$. Work continued on Readiness Assessment activities.

Construction personnel reentered the tanks during the early part of the month and repaired the bubbler tubes that had been identified as being out of alignment during last month's inspection. Personnel took as-built data on all of the bubbler locations to assist with calibration of the tanks' level measuring devices during the upcoming test and checkout.

$\underline{\text { April }}$

The Main Facility subcontractor continued with construction activities. All tank vault roof slabs had been completed. Concrete was placed for all of the pump and valve vault except for the blockouts for installation of the valve extensions. Work on pipe supports in the pump and valve vault continued. Installation of HVAC equipment continued. Electrical work in the control room continued. Instrumentation cabinets and tubing work continued on the roof. MK-Ferguson Direct Hire work continued. Material turnover from the main facility subcontractor was $98 \%$ complete. Work continued on the installation of the LLLW line from the new valve box to Building 7877. Work continued on Readiness Assessment activities.

Continued development of draft operating procedures based on certified for construction information. Also worked to finish the draft functional test plan for the new tanks and their associated piping and transfer systems.

Conducted a tour for the ORNL and DOE-ORO Readiness Self-Assessment teams of the facility. The tour was a short orientation to provide personnel with general knowledge of the site and facility layout in preparation for review activities later this summer.

Completed the first draft of the main facility operating procedures (WM-LGWO-610.2.9) and provided a copy to Training personnel to begin development of training materials. Procedures would be walked down and validated during functional testing scheduled for later this summer (after the completion of construction). Also completed a large ( $\left.3^{\prime} \times 4^{\prime}\right)$ draft 
piping diagram showing the LLLW, water, instrument air, and chemical addition systems that would be used during test/checkout to assist in valve lineups of the facility. This drawing was a consolidation of 14 Engineering drawings.

$\underline{\text { Mav }}$

The Main Facility subcontractor continued with construction activities. Installation of the liner plate in the pump and valve vault was completed. All tank vault roof slabs were completed. Concrete was placed for all of the pump and valve vault except for the blockouts for installation of the valve extensions. Installation of HVAC equipment continued. Electrical work in the control room continued. MK-F Direct Hire work continued. Work continued on the installation of the LLLW line from the new 7830 valve box to Building 7877. Instrumentation and electrical work continued. Installation of the valve extensions for the pump and valve vault continued with concrete being poured for the first sixteen sleeves. Work continued on Readiness Assessment activities. The latest forecast for construction completion was July $31,1998$.

Completed the first draft of the Utility Systems operations (WM-LGWO-610.3.6) for Building 7856 and issued a copy to Training personnel to begin advance preparation of training materials. The draft would be completed after construction was completed on the electrical and instrumentation systems (mid-June at the earliest).

$\underline{\text { June }}$

The Main Facility subcontractor completed construction activities and worked formal punch listing activities. MK-Ferguson Direct Hire work continued. Work continued on the installation of the LLLW line from the new 7830 valve box to Building 7877 . Instrumentation and electrical work continued. Installation of the valve extensions for the pump and valve vault was approximately $50 \%$ complete. Based on the latest projection for installation of valve extension, tank level instrumentation calibration and functional testing was forecast to start in late July. Based on these dates the latest projection for the start of operations was December 4, 1998. Work continued on Readiness Assessment activities. The Readiness Determination Plan was transmitted to DOE on May 29 for signature.

$\underline{\text { July }}$

MK-Ferguson Direct Hire work continued. Instrumentation and electrical work continued. Instrumentation loop testing continued and where possible instrument calibration was underway. Installation of the valve extensions for the pump and valve vault was approximately $80 \%$ complete. Began utility system functional testing with completion of the instrument air system. The demineralized water skid arrived on-site to support the sump tests which were begun the last week of July. Personnel also began functional testing of the process water system. Several punchlist items were identified and turned over to 
MK-Ferguson personnel for completion prior to re-performing the tests. Approved the functional test plan for calibration of the six tanks' volume measurement instrumentation. Based on the latest projection for installation of valve extension, tank level instrumentation calibration and functional testing of the LLLW System was forecast to start in early August. Based on these dates the latest projection for the start of operations was December $4^{\text {th }}$. Work continued on Readiness Assessment activities. The Readiness Determination Plan was approved by DOE.

\section{$\underline{\text { August }}$}

MK-Ferguson Direct Hire work continued. Instrumentation and electrical work continued. MK-Ferguson personnel completed installation of the valve stems and operators at the new valve box and at Building $7856 \mathrm{pump} / \mathrm{valve}$ vault by the end of the month. Began calibration of the tanks' level instrumentation by beginning to fill tank the tanks with demineralized water. By the end of the month the calibration of the six tanks' level instrumentation was completed. Completed functional testing of the tank vaults' sump transfer pump after a line blockage was removed (blockage was a small rat that went through the diaphragm pump). Completed a cold alignment of the two electric motor Positive displacement pumps in preparation for their usage. In an effort to recover time in the schedule due to construction delays, LGWO personnel were performing functional testing on a 12 hour/day, 6 day/week schedule. Continued to identify punchlist items to Engineering personnel as a result of the functional testing that has been completed. Work continued on Readiness Assessment activities. During repairs to the J-1 discharge piping, it was found that heat had been applied to the final 18 inches of the pump in an apparent effort to assist in the alignment of the pump with the discharge piping in order to eliminate a reoccurring leak. The pump vendor was contacted and performed an inspection of the pump's interior (on August 31). No damage was observed to the pump's rubber stator. However, personnel also discovered that the flanges for the pumps' discharge spool piece were only rated for 150 psig instead of the design rating of $300 \mathrm{psig}$. Engineering at the end of the month was continuing efforts to procure replacement flanges and associated gaskets. Personnel also held a meeting with the Independent and DOE Readiness Assessment teams at the facility to discuss what demonstrations would be conducted as part of the review. Personnel agreed to a proposal by Line Management for an intertank transfer and a transfer from the pump/valve vault sump to the tanker loading area. Personnel were requested to develop a drill scenario based on comments made by the DOE RA team. Work continued on Readiness Assessment activities.

\section{September}

MK-Ferguson Direct Hire work continued. Instrumentation and electrical work continued. MK-Ferguson personnel completed painting of the interior of the pump/valve vault and began painting of the pump/valve vault roof with a flow diagram to assist in valve lineups by personnel. Also began painting in the middle pump room and worked to identify and seal cracks in the roof that were allowing water leakage into the pump/valve vault. LGWOS 
personnel received comments on the Phase 2 Functional Test Plan and began phase 2 of the functional testing after approval of the test plan. LGWOS personnel completed phase 2 of the functional testing with the exception of transferring water from Building 7856 thru the new transfer line into Building 7877. Conducted a tour of the construction site for BJC and DOE-ORO project management personnel to update status of testing and punchlist activities. Continued to identify punchlist items to Engineering personnel as a result of the functional testing that has been completed. Work continued on Readiness Assessment activities.

WMOD Training Personnel reviewed System Safety Analysis Report and Technical Safety requirements for building 7856 in support of the MVST Capacity Increase - LI Project. LGWOS personnel completed seven (7) procedure use examinations for Building 7856 Operations and Utility Systems Procedures.

\section{October}

MK-Ferguson Direct Hire work continued. MK-Ferguson personnel completed painting of the pump/valve vault roof with a flow diagram to assist in valve lineups by personnel. MKFerguson personnel completed working to seal penetrations on the vault roof to minimize inleakage into the facility. MK-Ferguson personnel completed closure of the east opening into the pump/valve vault by pouring the wall plug. Plant and Equipment worked on the tiein at the 7830 Valve Box, with MK-Ferguson to begin backfill of the excavation site early next week. LGWOS personnel continued valve labeling and walkdowns of the facility in preparation for upcoming operations/demonstrations. Engineering personnel completed welding activities in the pump/valve vault prior to closure of the side-wall entrance (which will result in its designation as a confined space). Engineering personnel completed installation of the final 300 psig flange on the discharge of positive displacement pump J-1. Engineering personnel performed test and balancing of the heat, ventilation, and air conditioning system at the facility. Personnel also performed a transfer using pump J-8 from tank W-35 to Building 7877 to test the newly installed transfer line. Continued to identify punchlist items to Engineering personnel as a result of the functional testing that has been completed. Work continued on Readiness Assessment activities. The Line Management RA team continued holding one to two meetings per week. The Independent Team and DOEORO Readiness Assessment Teams witnessed demonstrations on October 29 th at the facility along with an emergency drill to test site response. Some comments on procedures were made, with formal comments to be received next month. At the end of the month, work continued on Readiness Assessment activities, with closure by the Line Management team of all but 2 CRADs.

Approved the Building 7856 Operations procedure (WM-LGWO-610.2.9 R0), the Building 7856 Utility Systems procedure (WM-LGWO-610.3.6 R0), and a document change directive describing the computer console at Building 7856 (WM-LGWO-606.8R2-DCD1). 


\section{November}

MK-Ferguson Direct Hire and Plant and Equipment personnel continued to complete final punchlist activities. MK-Ferguson completed backfill activities at the 7830 Valve Box after Plant and Equipment personnel completed the tie-ins. LGWOS personnel accepted beneficial occupancy of the facility on Nov. 13 with a punchlist of pre-start and post-startup activities. The operating procedures were revised to incorporate comments from the independent Readiness Assessment Team. The independent Readiness Assessment Team completed their review and issued their report on Nov. 13 to the WMOD Director and to DOE-ORO personnel with a manageable list of pre-start findings (primarily focused on the identified punchlist activities). The report was hand delivered to DOE-ORO personnel so that the DOE Readiness Assessment team could begin their review activities on Nov. 16.

The DOE-ORO Readiness Assessment Team arrived on site on Nov. 16 and began review of project activities. The LMER Line Management/Independent RA Teams had identified a manageable list of pre-start findings to the DOE-ORO team prior to the commencement of their review. All of this list was closed out by Nov. $19^{\text {th }}$ by the Independent RA Team and documentation provided to DOE-ORO RA Team members.

Daily closeouts were held with LGWOS personnel and the final closeout was held on Nov. 20. The DOE-ORO team identified 6 pre-start findings during their review, 5 of which had been closed by the closeout on Nov. 20. The team also identified 4 post-start findings, 2 of which had been closed by the closeout on Nov. 20 .

Overall feedback from the DOE-ORO RA Team was very good (this review was identified as the best review they had performed) with the following specific complements:

- Kudos to the Line Management/Independent RA teams for a very thorough review and identification of appropriate pre/post-start findings. Special identification was made of the Independent RA Team Leader and his assistant for their efforts during the reviews.

- Very complementary of the evidence files and the indexes which allowed the DOE personnel to complete their review in a timely manner.

- Kudos to WMOD Training Office supervisor on the training program and documentation of personnel training.

- Kudos also to the LGWOS Waste Disposal Supervisor on personnel training.

- $\quad$ Kudos to the System Safety Engineer supporting LGWOS for assistance with the review of the Facility Authorization Basis documentation. 
- $\quad$ And finally, but certainly not in the least, Kudos to LGWOS and Engineering personnel for prompt closure of issues identified during the DOE-ORO team's review so that the final list had only 1 pre-start and 1 post-start findings identified by DOE.

Closure evidence for the pre-start finding on calibration of the stack sampler along with a schedule of corrective actions for the post-start findings was submitted to the DOE-ORO Readiness Assessment Team Leader along with a request for permission to place the facility in service occurred on Nov. 24. Performed a training orientation for the newly assigned DOE program manager on Nov. 25 to close a pre-start finding against DOE-ORO on his qualifications. The authorization to place the facility in servicewais expected early next month to meet the milestone date of Dec. 4.

\section{December}

Received approval on Dec. $3^{\text {rd }}$ from DOE-ORO to place Building 7856 in service after successful completion of the Readiness Assessment activities. This met the Bechtel-Jacobs Company (BJC) milestone date of Dec. $4^{\text {th }}$ for the facility to be operational. This milestone was met with much dedication and hard work by the project team members, who were able to work around several months of construction delays to meet this date. This provided an additional 550,000 gallons of usable storage for LLLW concentrate at ORNL.

Completed the first transfer of LLLW to the new Melton Valley Storage Tanks Annex (Building 7856) on Dec. 15. Personnel transferred approximately 32,287 gallons from tank W-28 at Building 7830 (Melton Valley Storage Tanks) to tank W-35 and 13,450 gallons from tank W-27 to tank W-35 at Building 7856.

Completed the second transfer of LLLW to the new Melton Valley Storage Tanks Annex (Building 7856) on Dec. 22. Personnel transferred approximately 22,000 gallons from tank W-24 at Building 7830 to tank W-31 and 9,300 gallons from tank W-27 to tank W-35 at Building 7856.

Completed the third transfer of LLLW to the new Melton Valley Storage Tanks Annex (Building 7856) on Dec. 29. Personnel transferred approximately 13,000 gallons from tank W-22 at Building 2537 (LLLW Evaporator Service Tanks) to tank W-33 at Building 7856.

\subsubsection{WC-14 Remediation}

This was a successful time critical removal action under the Comprehensive Environmental Response, Compensation, and Liability Act of 1980 to remove the sludge, which is a remote-handled (RH) transuranic (TRU) waste containing PCBs regulated under the Toxic Substance Control Act (TSCA) as well as Resource Conservation and Recovery Act contaminants, from the tank by June 30,1998 . After removal and dewatering, the sludge was be stored in Building 7833, the Remote Handled TRU Storage Bunker. Although 7833 is not 
permitted as a TSCA storage facility, waivers were obtained from the Environmental Protection Agency to allow storage of the WC-14 waste.

$\underline{\text { January }}$

Subcontractor personnel continued with design, fabrication, and testing of the steel vessel that would provide for activated carbon treatment of the liquid effluent from the sludge dewatering operation. The filter vessel was scheduled to be delivered in early February. Bench-scale testing of the WC-14 waste was completed. Based on the results, personnel recommended a combination of filter cloth and powdered activated carbon as the most effective means of removing the suspended solids from the WC-14 waste. The polychlorinated biphenyls (PCBs) were attached to the solids.

\section{February}

The Phase II functional test of the WC-14 sludge removal and dewatering system was successfully completed on Feb. 6 . The test was conducted by the sludge removal contractor, assisted by LMER radiation surveillance personnel. The test demonstrated filling of the waste drum, vacuum dewatering of the waste, pumping of the filtrate through the external carbon filter, and the use of remote tools for disconnecting and plugging the waste drum. With the approval of the LMER project management assessment team, the WMRAD Director, and the concurrence of DOE staff, processing of the WC-14 waste was initiated on Feb. 6. Personnel removed much of the material from the tank that was readily pumpable during the first week of work. At the end of the week personnel were working to remove sludge that had built up on the sides of the tank that was not readily pumpable. The dewatering process was very slow and limited sludge transfers from the tank to about $10 \mathrm{gal}$ per day. The final 2-3 inches of sludge in the bottom had the consistency of oatmeal and was a challenge to get out. Representatives from the TDEC were given the opportunity on Feb. 27 at 1330 to inspect the interior of Tank WC-14 using a video camera. Based on their inspection, they provided verbal authorization for Lockheed Martin to fill the tank with grout (written confirmation will follow). Grouting of the tank would be done in early March, weather permitting. This authorization did not mean that the $\mathrm{WC}-14$ project was completed. Dewatering of the sludge would continue in early March to meet the waste acceptance criteria for Building 7883 .

\section{$\underline{\text { March }}$}

Completed grouting WC-14 about noon on March 4th. The tank appeared to be very "clean," i.e., there was very little solid material left in the bottom when the grout was added. The subcontractor completed dewatering of the sludge drums.

Received the "official" results of the analysis that Chemistry and Analytical Sciences performed on the filtrate from the WC-14 sludge dewatering operation. The sample was 
analyzed for PCB concentration only. The filtrate contained less than $1 \mathrm{ppm}$ PCBs, well under the regulatory limit. LGWO personnel then pumped the filtrate to the Liquid LowLevel Waste System. The only remaining tasks on the WC-14 project in early April were transfer of the dewatered sludge to 7883 and demobilization of the subcontractor's equipment.

$\underline{\text { April }}$

Solid Waste Operations picked up the shield cask and drum containing the WC-14 dewatered waste April 2 and moved it to the Solid Waste Storage Area (SWSA). They also helped load the other contaminated equipment into the LMER and subcontractor's B-25 boxes. The subcontractor then disassembled the berm wall on April 2. At the jobsite, LGWOS had a B25 box containing the $\mathrm{PCB}$-contaminated equipment that would be stored for possible future use. Personnel were working on getting the paperwork in order for shipping the subcontractor's equipment back to their facilities. That included their B-25 box, a B-12 box, the high integrity container that served as the filtrate holding container, the berm wall, and a couple of other items.

\subsubsection{Building 7877 Treatment Operations}

During the year, three Out-of-Tank Evaporation (OTE) campaigns were completed by LGWOS and Chemical Technology Division personnel. These campaigns each treated approximately 25,000 gallons of LLLW supernate in an effort to provide additional storage space for LLLW concentrate. At the end of the year, personnel were working to make modifications to Building 7877 to allow usage of the OTE System along with the Cesium Removal Treatment System in series during early 1999.

\section{$\underline{\text { January }}$}

Campaign 98-2 operations began on Monday January 12, about 11:00 am. Startup was routine, but this particular supernate batch had a tendency to foam upon boiling. This made it necessary to maintain a low evaporator shell level to prevent the foam from carrying into the vapor separation section of the unit and contaminating the distillate. At low shell levels, less of the heat exchange surface was contacted and evaporation was slower. An antifoaming agent was added to the system, but it was only marginally effective. Distillate conductivity was higher than anticipated; however, analysis of the distillate indicated that cesium concentrations were less than $200 \mathrm{~Bq} / \mathrm{L}$ which was well within the acceptance criteria for the Process Waste System. On Jan. 30 campaign 98-2 was shut down due to continuing system problems. The major problems continued to be associated with the wastewater having a more neutral $\mathrm{pH}$ than in previous operations. It was suspected that crystallization of salts from heating of the foam on the heat exchange tubes caused malfunctions of the level control sensors in the evaporator shell and concentrate recirculation tank. The level instruments, which were a float type device, could become fouled from the dried crystals and prevent 
movement of the floats. One float was eventually restored but the other one was still not responding at the end of the month. A dilute acid wash was being planned in a final attempt to restore operability without removing the float. The total amount processed for campaign \#2 was 16,156 gal with 7,909 gal of distillate worked off. Training of additional Waste Management operating personnel progressed well.

The problems with slow processing rate and some of the mechanical problems appeared to be associated with foaming of the supernate. Practical experience with LLLW and evaluation of the tank chemistry indicated that the neutral $\mathrm{pH}$ of the current W-29 supernate might be causing it to foam when boiled. It was suspected that supernate with higher $\mathrm{pH}$ would be less likely to foam. Samples of supernate from W-24 (targeted for OTE \#3) and W-29 would be obtained to determine $\mathrm{pH}$. If the $\mathrm{pH}$ was low, caustic would be added to $\mathrm{W}-24$ to elevate $\mathrm{pH}$ prior to transfer of the supernate to W-29. The samples would be boiled in the laboratory as a qualitative check of foaming tendency. Various antifoams would be tested if foaming was still observed.

\section{$\underline{\text { February }}$}

Personnel continued maintenance activities after campaign 98-2 was shut down on Jan. 30 due to continuing system problems. The major problems were associated with the wastewater foaming when evaporated. It was suspected that crystallization of salts from heating of the foam on the heat exchange tubes caused malfunctions of the level control sensors in the evaporator shell and concentrate recirculation tank. The level instruments, which were a float type device, could become fouled from the dried crystals and prevent movement of the floats. One float was eventually restored in early Feb. but the other one had to be washed with a dilute acid wash to restore operability without removing the float. The total amount processed for campaign $\# 2$ was $16,156 \mathrm{gal}$ with 7,909 gal of distillate worked off. At the end of the month personnel collected a supernate sample from tank W-29 for Technical Safety Requirements characterization and delivered the sample to Laboratory personnel for analysis. This sample was required before campaign 98-3 could begin (tentatively scheduled for March 9).

The problems with slow processing rate and some of the mechanical problems appeared to be associated with foaming of the supernate. Practical experience with LLLW and evaluation of the tank chemistry indicated that the neutral $\mathrm{pH}$ of the current $\mathrm{W}-29$ supernate might be causing it to foam when boiled. It was suspected that supernate with higher $\mathrm{pH}$ would be less likely to foam. Samples of supernate from W-24 (targeted for OTE \#3) and W-29 were obtained to determine $\mathrm{pH}$. If the $\mathrm{pH}$ was low, caustic would be added to $\mathrm{W}-24$ to elevate $\mathrm{pH}$ prior to transfer of the supernate to W-29. The samples were boiled in the laboratory as a qualitative check of foaming tendency. Various antifoams were also tested. 
March

Laboratory work on W24/W29 samples to evaluate foaming tendency and evaluate antifoams was completed in early March. Two antifoam products appeared to be effective for controlling the foaming of the W24/W29 supernate mixture. Tank W29 was sampled February $27^{\text {th }}$ to evaluate composition for safety requirements. Though the alpha and suspended solids content were elevated compared to previous samples, the composition met the requirements of the Technical Safety Requirements for the OTE operation.

Chem Tech and LGWOS personnel began operation of OTE Campaign 98-3 on March 9th. Personnel used an anti-foaming additive to control the foaming that began during the previous campaign. A revision to the operating procedures was made to allow better identification of the gross alpha contributors for TSR calculation compliance. Some foaming was experienced during early batches of the supernate, but it did not continue. This was unexpected, since laboratory testing indicated that foaming would be a problem. Decontamination factors (DFs) were not as high as they had been in earlier campaigns due in part to the higher concentration of cesium in this batch of feed. Since the cesium content of the distillate, at $4,600 \mathrm{~Bq} / \mathrm{L}$, was higher than the waste acceptance criteria $(400 \mathrm{~Bq} / \mathrm{L})$ for the Process Waste system, a waiver was prepared by LGWOS to accept the distillate. The Process Waste System can handle limited quantities of feed with somewhat higher Cs content. The latest data indicated that a DF of 460,000 was being achieved, which was still indicative of very good performance. Operations for Campaign 98-3 were completed on Saturday, March 28 after processing a total of $22,400 \mathrm{gal}$ and producing $13,300 \mathrm{gal}$ of distillate. The volume reduction for this run was $59 \%$ and the goal of 12,000 gal of distillate was exceeded by 1,300 gal. The system was shut down and residual liquids in the system were drained back to the MVSTs. Water flushing and acid cleaning activities would be performed in early April to prepare for repair work in the concentrate discharge pump that developed a leak during this campaign.

Preparations were underway at the end of March for Campaign 98-4. Supernate from tank W25 was chosen for processing in the next campaign. The W25 supernate was likely to have the lowest nitrate content in the MVSTs and should therefore provide more distillate. A sample was being obtained to check the nitrate level and $\mathrm{pH}$. Caustic might be added to W25 or W29 if the $\mathrm{pH}$ was lower than 10.

April

Collected a sample from tank W-29 at the Melton Valley Storage Tanks (Building 7830) and submitted to laboratory personnel for analysis in preparation for the upcoming Out-of-Tank Evaporation Campaign 98-4. Worked to repair the sampler system for the Out-of-Tank Evaporator System installed at Building 7877 in preparation for the startup of Campaign 98-4 in early to mid-May. Restrictions in the piping system were ruled out and Instrumentation and Controls personnel were asked to check the solenoid operators on the sampler valves to 
see if one or more valve might not be fully opening. The campaign would begin after funding issues were resolved to cover maintenance costs associated with operating this demonstration system on a routine basis.

$\underline{\text { May }}$

Completed repairs to the sampler system for the Out-of-Tank Evaporator System installed at Building 7877 in preparation for the startup of Campaign 98-4 in mid-May. Plugged solenoid operated valves were identified as the cause of the flow restrictions. Personnel then completed the prestart checkout of the Out-of-Tank Evaporation System in preparation for the start of OTE Campaign 98-4 next month.

$\underline{\text { June }}$

Began Campaign 98-4 on June 1 and completed operations on June 19 after reaching the goal of producing 10,000 gallons of distillate for transfer to the Process Waste Collection and Transfer System for future treatment.. The supernate foamed during the process, and antifoam and caustic additions were used to control it with moderate success. Distillate purity had been poor at the beginning of operations with decontamination factors of about 20,000 , but waivers were prepared for acceptance in the Process Waste Collection and Transfer System. Processing was not interrupted until Friday, June 12 when the Pump Module decant pump failed. The pump was replaced with only about $7 \mathrm{hrs}$ down-time (a failed diaphragm was suspected as the cause of the failure). At about 1900 hours on June 13, the level indicator in the concentrate recycle tank failed. Trouble-shooting and eventual replacement of the level probe required about 21 hours. On June 19, the campaign was completed and personnel began decontamination associated with placing the Out-of-Tank Evaporation System in standby. No further campaigns were scheduled for fiscal year 1998.

$\underline{\text { July }}$

Completed decontamination and cleanup of Building 7877 associated with the completion of Out-of-Tank Evaporation Campaign 98-4. Supported Chem Tech and Plant and Equipment personnel with the reinstallation of the Cesium Removal system at Building 7877, which is planned to be used next fiscal year.

August

Plant and Equipment personnel continued installation of the Cesium Removal system at Building 7877 (LLLW Solidification System). Modifications to allow usage of the OTE and/or the Cesium Removal System as needed continued. 


\section{September}

LGWOS personnel collected 5 gallon samples from tanks W-29 and W-30 at Building 7830 (Melton Valley Storage Tanks) at the request of Chem Tech personnel to support upcoming operations.

\section{$\underline{\text { October }}$}

A meeting was held with Chem Tech, LGWOS, and System Safety Engineering personnel to discuss future work activities and to identify any required changes to the facility authorization basis. Chem Tech personnel were preparing a detailed description of activities and equipment modes to assist System Safety Engineering personnel in their evaluations.

\section{December}

Provided comments to Chem Tech personnel on a draft memorandum of understanding (MOU) defining responsibilities for the 1999 activities at Building 7877 and the Solid-Liquid Separation System. Held meetings with Chem Tech, WMOD, and BJC personnel to discuss the upcoming operations, with an emphasis on the level of readiness activities required.

\subsubsection{Sludge Mobilization Demonstration}

This demonstration used technology provided by AEA Technologies to show the effectiveness in mobilizing the settled sludges in the evaporator service tanks. Once the sludges were mobilized, they were transferred to the Melton Valley Storage Tanks. Personnel completed the demonstration tank W-21 in January and proceeded to empty tanks $\mathrm{W}-22$ and $\mathrm{W}-23$. At the end of the year, personnel were preparing for installation of a mobilization system in tanks C-1 and C-2 at Building 2531 .

\section{$\underline{\text { January }}$}

Attended several meetings this month in support of the current sludge mobilization activities being performed by AEA. Also provided assistance/coordination in getting Health Physics support and equipment for AEA personnel as they prepared their equipment for restart. On January 13 the final transfer was made from W-21 with approximately 4,500 gallons of supernate and suspended sludges being transferred to W-22. Personnel then tested the transfer jets from W-21 to ensure its adequacy as the evaporator feed tank on January 14. After the tests were successfully completed, AEA personnel relocated their mixing equipment to the sludge jets for W-22 and began operations. On January 20 the first slurry transfer of 28,440 gallons from W-22 was performed. It appeared that the first mixing was fairly successful, transferring approximately $50 \%$ of the sludge in Tank W-22 to a storage tank at the Melton Valley Storage Tanks (Building 7830). Approximately 12,000 gallons of supernate were added to tank W-22 after this transfer for the second mixing. On January 26 
personnel completed the second transfer of sludges by transferring 8,180 gallons from W-22 to $\mathrm{W}-25$ and 5,480 gallons from W-22 to W-24. Personnel then refilled W-22 with 6,210 gallons of supernate from tank C-1. In preparation for the next transfer, personnel on Jan. 27 transferred 11,350 gallons from W-26 to C-1 and 8,130 gallons from W-26 to C-2. On January 27 personnel sampled the remaining sludge in W-22 for evaluation of the upcoming nitric acid addition. On January 30 personnel completed the third transfer of sludges by transferring 4,940 gallons from W-22 to W-25. Personnel then transferred approximately 265 gallons of nitric acid waste to W-22 to enhance mobilization of the remaining sludge and transferred 2,392 gallons of supernate from C-1 to W-22. The transfer results continued to be good. For each transfer it appeared as if approximately one-half of the remaining sludge volume is being mobilized. Beginning the fourth cycle there were approximately $700-800$ gallons of sludge remaining in the evaporator.

Also attended a meeting to review the upcoming sludge mobilization activities for tanks $\mathrm{C}-1$ and $\mathrm{C}-2$. After this meeting to review the project, a presentation was given to DOE and indications are that it was well received. Funding to proceed with this project was expected to be approved.

\section{February}

On Feb. 2 personnel completed the fourth cycle by transferring 4,825 gallons of suspended and dissolved sludges from W-22 to W-25 at Building 7830. Personnel then refilled W-22 with approximately 3,220 gallons of supernate from tank C-1. Also transferred approximately 260 gallons of nitric acid waste to $\mathrm{W}-22$ to enhance mobilization of the remaining sludge. Personnel added an additional 100 gallons of dilute nitric acid on Feb. 5 to aid in dissolving the remaining sludge. The transfer results continued to be good. For each transfer it appeared as if approximately $1 / 2$ of the remaining sludge volume was being mobilized. On Feb. 9, personnel sampled tank W-22 to confirm the effectiveness of the nitric acid addition. After receiving confirmation from the lab, personnel performed the last transfer of 5,285 gallons from W-22 to W-25 (at Building 7830). As a result of this project, the sludge volume in W-22 was reduced from approximately 7,000 gallons to approximately 200 gallons. Following this transfer, AEA personnel placed their system in standby condition, where it will remain until they are mobilized later this year to empty sludge from W-23.

Met with several organizations to discuss planned sludge mobilization activities associated with tanks C-1 and C-2 at the LLLW Evaporator Facility (Building 2531). AEA was designing and fabricating components to be used for these activities and was requiring input from Lockheed-Martin to continue with their work. 


\section{March}

Construction personnel, along with oversite from AEA personnel, realigned the hose connections in the Building 2537 Pump and Valve vault in preparation for the upcoming sludge mobilization work planned for tank W-23. During this effort a remote operated camera, which had been located in tank W-22, was moved to tank W-23. Also held a meeting with personnel from Engineering and AEA Technologies to discuss the upcoming sludge mobilization plans for tank W-23. The current plans were to begin mixing operations in W23 in mid-April and complete the effort by mid May.

$\underline{\text { April }}$

Supported efforts to begin the sludge mobilization/removal task for tank W-23. Efforts included assisting in coordinating with support organizations to cover the project, changeout of the HEPA filters on the AEA equipment skid, providing training to AEAT personnel on the LLLW system at ORNL, locating equipment and components to support test and check out of the system, and providing AEAT personnel with communication equipment. The project began mixing the contents of W-23 in mid-May. On May 23th, mixing had been underway for $\sim 1$ week and sample results showed that the mixing was doing too well (first sample showed suspended solids content to be $>11 \%$ ). The solids being suspended by the mixing exceeded that allowed by the Work Authorization. Discussions and meeting occurred to address the situation. Personnel collected additional samples over the weekend and reduced the mixing activity in W-23 in an effort to reduce the amount of Total Suspended Solids in the slurry. On April $27^{\text {th }}$ personnel performed the first transfer from Evaporator Service Tank W-23 to the Melton Valley Storage Tanks (Building 7830). Approximately 25,026 gallons were transferred from W-23 to W-24 and 7,180 gallons were transferred from W-23 to W-25. Personnel then transferred 3,530 gallons from W-26 to W-23 and restarted the AEA Sludge Mobilization System. On April 28th transferred an additional 4,100 gallons from W-26 to W-23 along with an additional 1,040 gallons of flush water to assist in the mixing operations. On May $1^{\text {st }}$ personnel completed the second transfer of suspended sludges to Building 7830. Approximately 18,095 gallons were transferred from W-23 to W-25. Personnel then transferred 6,350 gallons from W-26 to W-23 and restarted the AEA Sludge Mobilization System. Based on the system's excellent performance during the first two transfers, it was felt that the third transfer would complete the operations during early May.

$\underline{\text { May }}$

The effort to mobilize and remove the sludge from the W-23 Evaporator Service Tank was completed. On May $4^{\text {th }}$ completed the third transfer from W-23 to the Melton Valley Storage Tanks (Building 7830) by transferring approximately 8,177 gallons from W-23 to W-26. The task was completed almost two weeks early with only $\sim 750$ gallons of sludge remaining in the tank. The vendor, with assistance from LGWO, demobilized and put their equipment in storage. 
Attended a meeting to discuss the upcoming project to mobilize the sludge in the C-1 and -2 Evaporator Service Tanks.

$\underline{\text { July }}$

Provided assistance to Engineering in support of the upcoming C-Tank Sludge Mobilization effort. Support was provided by studying and performing field tests to determine how much vacuum could be achieved in the $\mathrm{C}$-Tanks. Also performed additional testing on the off-gas system of the C-1 and C-2 Evaporator Service Tanks. This testing was being performed in support of the upcoming AEAT sludge mobilization project. The purpose of the testing is to determine the maximum amount of vacuum that can be achieved in the tanks.

\section{October}

Attended a meeting to discuss the upcoming AEAT sludge removal project of the $\mathrm{C}$ tanks at building 2531 .

\section{November}

Met with engineering personnel to review field work on the upcoming AEA Technology sludge mobilization work on the C-1 and -2 tanks. The field work being performed was to do a trial fit of a "charge vessel" into modified openings in the tanks. The work was performed during the first week of November and was successful.

\section{December}

Provided support during the month for the upcoming AEA activities which will mobilize and remove sludge from the $\mathrm{C} 1$ and $\mathrm{C} 2$ Evaporator Service Tanks. LGWOS personnel also provided comments to project personnel on the readiness assessment plan for this activity.

\subsubsection{Miscellaneous}

$\underline{\text { January }}$

Began work on developing an installation package for additional liquid level monitoring instruments for tanks C-1 and C-2 at Building 2531 (LLLW Evaporator Facility). These new level instruments will provide accurate level measurements in the event the tanks' existing bubbler tubes plug. 


\subsection{WOCC Data Acquisition System (DAS) and Distributed Control System (DCS)}

\subsubsection{Distributed Control System}

January

Completed faceplates and trends for Building 2600. Completed an update of Area 1 and Area 3 maps. Edited tag names for the new HOG Condensate Collection Tank and corrected its display. Updated and added area menus to display screens. Installed ZIP drive to Engineering work station for hard drive backup. Zip drive cartridges can be used to edit, create displays, tags, faceplates and menus on or off site as needed.

\section{$\underline{\text { February }}$}

Held a meeting with personnel providing the upgrades to the Distributed Control System operating consoles. A meeting was held with the vendor's president to resolve several software "bugs" that were in the latest delivery. Received assurances that personnel would be working daily with LMER personnel to resolve problems over the next few weeks so that personnel could begin final development of the system displays and alarm architecture.

Continued with display development for the DCS consoles. Updated the Area 1 and Area 3 map displays. Corrected errors associated with the new hot off-gas collection tank (F-2195). Developed several new graphics, faceplates, and trend displays for tank F-2103 at Building 2600. Assisted Instrumentation and Controls personnel with the migration of the existing signal database from the original plant fiber optic loop to the higher speed Infi90 loop. This will eliminate the need for a "bridge" station to allow communications between the two different communication highways. After the migration, modified the tag database for Loop 1 to suppress High Alert signals when the equipment goes into High Alarm. Also cleaned up several old files on the engineering workstation and backed up all of the software on the station. In addition, updated the signal (tag) database for the DCS replacement consoles to match the database for the existing consoles.

\section{March}

Continued working to identify software problems in the latest version delivered by the vendor. Some problems were resolved, however several items were not adequately addressed. The vendor was notified of the problems and personnel were awaiting a response at the end of the month. Project personnel were informed in mid-March that vendor support has been very inadequate, with several days required to even receive a return phone call and that when personnel did contact the vendor, the personnel were not available to address the problems. Project personnel were working at the end of the month to obtain better interface support from the vendor. 
Continued with display programming of the DCS console. Created graphics, faceplates and trend screens for Building 2568. Assisted Instrumentation and Controls personnel in verifying graphic screens between the existing and new DCS consoles. Adding changes to the new system that had been made since the initial delivery and programming of the replacement consoles.

\section{$\underline{\text { April }}$}

Continuing verification of graphic screens between the existing consoles and the replacement systems. Continuing to add changes to the new system that have been made since the original development of screens for the replacement consoles.

Competed display programming of the DAS console. Created graphics, faceplates and trend screens for Building 2568. Also completed screens/updates for Bldg 3025 .

May

Completed evaluation testing of the replacement system software and accepted the final modifications. Continued verification of graphic screens between the existing system and the replacement system. Continued to add changes to the replacement system that were made since the original conversion was completed. Began evaluating any necessary changes in the Area map displays and menus before moving to Area 1 (Bethel Valley LLLW) facilities. At the end of the month was evaluating the displays for Building 2649 (Transported Waste Receiving Facility).

Provided software modifications to the DCS field software to define a more accurate look-up table for the tank levels for tanks W-21, -22 , and -23 at Building 2537. This modification was requested so that the DCS numbers would match the displays on the existing DAS system. At the end of the modification the difference between the two systems was approximately 20 gallons (for 50,000 gallon capacity tanks).

$\underline{\text { June }}$

Continuing verification of graphic screens between the existing and replacement systems. Continued to add changes to the new system that had been made since original development efforts were completed. Started upgrading Area maps and menus and then moving to Area 1 facilities. At the end of the month personnel were working on Building 2649 Graphics screens.

Continued development of Graphic display screens for the Melton Valley Storage Tanks Capacity Increase Line Item Project. Screens will be used during functional testing scheduled to begin in July. 
$\underline{\text { July }}$

Several problems arose during the month. System is not functioning properly. In contact with the vendor, who has yet to provide a solution. Spent the majority of July making programming changes to the system before the problems began to occur. Also worked on draft operating procedures for the new consoles.

\section{August}

Several problems arose during month. System is not functioning properly. A process program was failing when two or more machines were booted. The vendor was contacted under the service/support contract established earlier this year, but was unresponsive to the problem. LGWOS and Instrumentation and Controls (I\&C) personnel with little knowledge of the Unix Operating System finally had to resolve the problem by bringing on-line a routine that would synchronize the time and date between all machines (Network Time Protocol). It solved the problem. Completed a draft copy of the operating procedures for the new system.

\section{September}

Started the upgrade installation of UNIX systems from version 3.2D to 4.0D to comply with Year 2000 requirements. At time having problems with disk space needed for installs. Continuing to work with the vendor to resolve database crash problem with the operating consoles' system.

\section{October}

Several problems arouse during month. The system is not functioning properly. A process program was failing when two or more machines were booted. Upgraded the UNIX operating system for ORNLALF2 to UNIX 4.0D. This upgrade will make the systems year 2000 compliant. It was found that additional subset software was loaded on these DEC workstations that could possibly be interfering with the operation of the DCS software. A decrease in hard disk space used with the upgrade (previously $>86 \%$, now $<45 \%$ ) was noticed. At the end of the month personnel were working to have the system boot up running the DCS software and obtaining hardware and software to login from remote locations to allow system programmers to restart, test and troubleshoot the software in case of off hour failures.

\section{November}

Several problems arose during month. System is not functioning properly. A process program "'DbClient" was failing when two or more machines were booted. Upgraded the UNIX operating system for ORNLALF1 to UNIX 4.0D Two (on workstations ornlalf1 and ornlalf2). The systems are booting up running the DCS software, however problems with 
startup scripts are still a concern. Startup scripts were found to be written for a SUN SPARC Workstation and not a DEC Workstation. The Unix Operating Systems are somewhat different. Cannot upgrade operating system for ornlalf4 (located at Building 7856) until checkout testing and reviews are completed. Workstation ornlalf] is also monitoring Building 7856 from its Building 3130 location.

Workstation ""ornlalf3"" is currently down with a suspected power supply problem. As a result, personnel are working with $I \& C$ and DEC to add a monthly on-site maintenance for the DCS workstations.

\section{December}

Enabled the signals for the new Building 2568 off-gas and cell ventilation filter pits. Personnel will have to incorporate a RCM control button on the DCS to inhibit incoming alarms from the standby filter banks.

Several problems were continued during the month in the DCS monitoring Building 7856. A process program used to synchronize databases at multiple locations was failing when two or more machines were in service. Personnel upgraded the UNIX operating system for ORNLALF3 to UNIX 4.0D. Two (ornlalf1 and ornlalf2) systems were in service running the DCS software and were not crashing as long as personnel did not try to use the process program to synchronize their databases; however problems with startup scripts were still a concern. Startup scripts were written for a SUN SPARC Workstation and not the provided DEC Workstation. This is a problem due to the different commands the two workstations use. At the end of the month, personnel had not upgraded operating system for ornlalf4 (located at Building 7856) until personnel receive word on the status of startup scripts for a DEC workstation. Personnel were also awaiting word on how to solve the database synchronization problem. Maintenance contracts were obtained with Digital Equipment Corporation for 24-7 monthly on-site maintenance for all of the workstations.

\subsubsection{Year 2000 Activities}

\section{February}

Held a meeting with a sales representative for the existing DCS manufacturer to discuss new product features and to hear a discussion on evaluations for the year 2000 software bug. Supplied the representative with a list of existing DCS hardware for evaluation to determine if any components require upgrades for protection from the year 2000 software bug. 


\section{March}

Continued to work with the DCS field hardware vendor to complete a Year 2000 evaluation of existing hardware. Supplied the vendor with an inventory of existing components and requested a quote for performing the evaluation.

\section{$\underline{\text { April }}$}

Maintained contact with the sales representative for the DCS field hardware on the Year 2000 issue with the current hardware. Personnel are developing a full inventory of installed equipment so that a quote can be obtained for performing an evaluation of the hardware. The evaluation will determine what, if any, upgrades are required to ensure no problems develop at the start of the year 2000 .

\section{August}

Year 2000 Software Concerns - Year 2000 concerns have been brought up about whether the LGWOS systems are year 2000 compliant. The following activities are presently underway: - Upgrading all firmware in the Process Control Units for the DCS as well as identifying options for upgrading the DCS operator consoles and Engineering Work Station to year 2000 compliancy. Personnel have been pursuing contacts with the equipment vendor throughout the year to identify which equipment in service would need upgrades. The list of equipment was finally received last month.

- $\quad$ Awaiting a proposal from Engineering on upgrading the existing WOCC DAS system to interface with the DCS.

- Began evaluations of Programmable Logic Controllers (PLCs) used in LGWOS facilities to determine the number (if any) requiring firmware upgrades.

- $\quad$ Requested Engineering provide documentation for Year 2000 Compliancy for the new PLCs and DCS Replacement Consoles being installed as part of the MVST-CI Line Item Project

\section{September}

Identified necessary upgrades for the Distributed Control System and placed a purchase order with the existing system's supplier for firmware upgrades for the field Process Control Units and for replacement operator consoles and software that is Year 2000 compliant. Also identified a plan of action for addressing the Data Acquisition System's Year 2000 software concerns. The DAS, due to the age of its software (approximately 15 years old) is much harder to address due to the lack of available support (very few companies have been identified to supply possible assistance in the necessary upgrades). Senior management was notified of the problems that have been identified to date. 


\section{October}

Year 2000 Concerns have been brought up about the LGWOS systems being year 2000 compliant. Equipment is being procured for upgrade the DCS to full year 2000 compliancy. The upgrades are expected to be delivered by early January 1999 .

Engineering has submitted a proposal to upgrade the existing DAS system as a General Plant Project. However, even if funding was approved, it would be doubtful that implementation could be completed by the end of next year. Personnel have been working with third party vendors to convert the existing DAS system software to run on a previously procured mainframe system. Software was transmitted to one vendor to assist them in developing a quote for the conversion

\section{November}

Continued to supply information to Bechtel Jacobs Company LLC concerning the status of embedded systems used throughout LGWOS facilities. Review shows LGWOS is in good shape with its embedded systems. Also continued to pursue third party assistance with the planned upgrades to the DAS to make it Year 2000 compliant. A copy of the DAS configuration was supplied to a vendor, who is expected to supply a quote for the upgrades sometime in December. Arrival of the DCS upgrades is scheduled for late December/early January.

\section{December}

The upgrades for the DCS consoles were received and are in the process of being checked out against the shipping invoice. Classes were scheduled for 4 LGWOS personnel to take during 
the months of January through March. The firmware upgrade had not arrived by the end of the month.

\subsubsection{Miscellaneous}

$\underline{\text { January }}$

PC Support - responded to several PC calls during month. Solved problem with "Tiffview" for Solid Waste Operations personnel. Tiffview was not installing properly. Manually configured 8 machines to use Tiffview to view single and multiple files. Followed up with a message to Computer Helpline to inform them that the problem had been solved and gave them the solution for future reference.

\section{February}

PC Support - installed an external backup drive for one LGWOS personnel.

Spare Parts Database - worked on relational database to keep records of spare parts and equipment. Basic database structure was completed and began work on development of input forms.

\section{$\underline{\text { March }}$}

PC Support - Worked on a printer problem for WMRAD Training organization. A Laserjet 5 SI would not work with another color printer and printer interface card under Windows 95. A conflict with the drivers was suspected so loaded drivers for a Laserjet 4 SI. That corrected the problem. Also installed WordPerfect 8 for one LGWOS personnel.

Spare Parts Database -Worked on relational database for the spare parts foreman to maintain records of spare parts and equipment. Have basic structure complete. Developed input screens for input of vendors, equipment, and spare parts. Will be working with the spare parts foreman to identify additional requirements of database.

April

Out-of-Tank Evaporation System (located at Building 7863) - Began review of the system (uses a programmable logic controller). Talked with $\mathrm{Chem}$ Tech personnel and requested that LGWOS personnel be involved in the upcoming hardware/software upgrades this summer.

PC Support - Installed anti-virus software on several personnel's computers throughout LGWOS. 
Spare Parts Database - Worked on relational database for the Spare Parts foreman to maintain records of spare parts and equipment. Completed the basic input screens. Will be working with the foreman in mid-May to develop task specific reports for the database.

$\underline{\text { May }}$

PC Support - Installed several copies of antivirus software throughout WMOD. Found Macro viruses on a few of the Technical staff's computers. Completed PRISM PC inventory.

Spare Parts Database - Continued work on a relational database for the LGWOS Spare Parts Foreman to maintain records of spare parts and equipment. Completed the basic input screens. Will be working with the foreman in early June on the reports screen.

$\underline{\text { June }}$

Spare Parts Database - Work with spare parts foreman on hold until upgrades are completed to his PC to support use of the database.

$\underline{\text { July }}$

Spare Parts Database - Continued working on relational database for the LGWOS Spare Parts Foreman to maintain records of spare parts and equipment. Completed the basic input screens and database structure. Found that since programming and field personnel have different sizes of monitors, the programmer must set his programming window to match the end users. Began looking at creating an application program to run the database and thereby make it more user friendly. Work progressed as time permitted.

WOCC Furniture - met with vendor who came for a site visit to measure layout for proposal on type and style of Operator Console furniture. A bid is expected in late August.

\section{August}

PC Support - Responded to three calls concerning failing programs or system not working.

Spare Parts Database - Working on relational database for LGWOS Spare Parts Foreman to maintain records of spare parts and equipment. This was placed on hold while personnel were concentrating on trouble-shooting the DCS Replacement Consoles.

\section{October}

Replacement furniture for the WOCC was ordered to support the system upgrades underway. 
November

WOCC control room furniture - Equipment was ordered. Some details came up as to color and left/right orientation of cabinets which will be resolved early next month.

December

WOCC control room furniture - Equipment was ordered. Some details came up as to color and left/ right orientation of cabinets. These questions will be taken care of in January. Furniture is scheduled to arrive around February 8th.

\subsection{Occurrence Reporting}

June

ORO-BJC-BJCWSTOPX-1998-0001, personal contamination, LLLW System, off-normal occurrence, June 11, 1998.

\subsection{Facility Authorization Basis}

January

Submitted the annual list of Unreviewed Safety Question Determinations (USQDs) for CY1997 to Office of Nuclear Safety personnel. Nineteen USQDs were developed for LGWOS operations, with four being classified as an Unreviewed Safety Question (USQ) requiring DOE-ORO approval prior to implementation. Two of the four were approved and implemented during CY1997. The other 2 were submitted in late December 1997 and would be approved in early 1998.

Reviewed the draft System Safety Analysis and Technical Safety Requirements documents for the new Melton Valley Storage Tanks facility (Building 7856). Provided comments to System Safety Engineering personnel.

Completed the annual review of 20 LGWOS facility authorization basis documents and submitted review documentation to the Office of Nuclear Safety personnel.

Cancelled the Preliminary Hazard Screening for Building 3127 since the facility is no longer under LGWOS control.

Issued an administrative guide to implement Nuclear Criticality Safety Approval \#60 (sludge mobilization activities within the existing LLLW System). 
Approved one USQD (non USQ) during the month: WM-LGWO-USQD-1998-1 R0 (Acid Dissolution of Evaporator Service Tanks Sludges). Also approved one USQD Screening: WM-LGWO-USQDSCREEN-1998-3 R0 (Acid Dissolution in Evaporator Service Tank W22).

\section{February}

Completed annual reviews for 15 Preliminary Hazard Screenings, 2 Hazard Screenings, and 2 Auditable Safety Analysis documents that are under LGWOS control. Submitted copies of the annual review documentation to Office of Nuclear Safety personnel.

Approved five Preliminary Hazard Screenings for LGWOS Industrial facilities: Buildings 2101 (LGWO Changehouse), 3158 \& 3159 (Cell Ventilation Duct Monitoring Stations for the 3025/3026 \& Isotope Area and the 3500 Area \& 4500 Area), 7802E (Sludge Removal Test Tank), 7813 (White Oak Dam), and 7881 (Post 24).

Received approval of Unreviewed Safety Question WM-LGWO-USQD-1997-17, Rev. 0 from DOE-ORO personnel. This USQ allowed personnel to increase the allowed transfer rate from Building 7966 (Monitoring and Control Station for Buildings 7920 and 7930) to the LLLW Evaporator Facility.

Presented the System Safety Analysis and Technical Safety Requirements documents for Building 7856 (Melton Valley Storage Tanks Capacity Increase facility) to the Laboratory Facility Authorization Basis Board (LFABB) for approval. The LFABB approved the documents, and they were transmitted to DOE-ORO for review/approval on Feb. 26. These documents were required to be approved prior to startup to provide the Facility Authorization Basis (as part of the LLLW System) for the new tanks.

\section{$\underline{\text { March }}$}

Received approval of the USQD Change Package for the replacement of the level instrumentation for Tanks W-21 through W-28, W-31, C-1, C-2, F-1401, F-1701, and F-1702 (WM-LGWO-USQD-1998-2).

Received the Safety Evaluation Report for the Building 7877 Safety Analysis Report and Technical Safety Requirements documents and began preparation of responses to the DOEORO reviewer's comments.

Received approval of the USQD Change Package for the replacement of the Bethel Valley Collection Tank and line serving Building 3025-E (WM-LGWO-USQD-1997-20).

Received approval of the USQD Change package for replacement of the plummet-type level instrumentation within the LLLW System (WM-LGWO-USQD-1998-2). 
Met with DOE-ORO personnel for informal discussion of the LLLW System Operational Safety Requirements (WM-LGWO-LLLW-OSR, Rev. 8) submitted 3 months ago for review and comment. Based on the discussions, LMER personnel would revise the submittal to delete proposed revisions that additional analysis calculations were requested for. This would allow the deletion of several OSR requirements for isolated LLLW tanks from the OSR in a timely manner. Personnel would submit revision 9 after the additional analysis calculations were completed.

Issued a letter to DOE-ORO personnel providing clarification on the Safety Evaluation Report DOE-ORO personnel had written to approve the LLLW System BIO revision (ORNL/WM-LGWO/LLLW/BIO/R1). With transmittal of the letter, the BIO revision was transmitted to the Procedures and Data Services group for controlled distribution.

Retired sixteen Unreviewed Safety Question Determination documents and safety assessments that had been incorporated in the LLLW BIO System revision 1.

\section{$\underline{\text { April }}$}

Received approval of the Unreviewed Safety Question (USQ) Determination Change Package for Transfer of the contents of the Old Hydrofracture Facility Tanks to the Melton Valley Storage Tanks (WM-LGWO-USQD-1997-21, Rev. 0). This connection to the intervalley transfer line was determined to be a non-USQ.

Completed the annual review of the following documentation and submitted review documentation to the Office of Nuclear Safety: Hazard Screening for the 3039 Stack Ventilation System (HS/3039/F/1/R0), Preliminary Hazard Screening for the Melton Valley Process Waste Pumping Station (ORNL/WM-LGWO/7952/PHS/R0), and the System Safety Analysis for Building 2099 (WM-LGWO-2099-SSA, R1). No revisions were identified for these documents.

$\underline{\text { July }}$

Received LFABB approval of revision 8-1 of the LLLW System Operational Safety Requirements document (WM-LGWO-LLLW-OSR) and began transmittal of the document thru BJC personnel to DOE-ORO personnel for review/approval. This revision was made to address informal comments from DOE reviewers of the original rev. 8 submitted earlier this fiscal year.

\section{$\underline{\text { August }}$}

Transmitted revision 8-1 of the LLLW System Operational Safety Requirements document (WM-LGWO-LLLW-OSR) to DOE-ORO personnel for review/approval. A meeting was also 
held with the DOE-ORO reviewers to discuss the changes and to facilitate a quick turnaround of this document. This revision was made to address informal comments from DOE reviewers of the original rev. 8 submitted earlier this fiscal year.

Presented the System Safety Analysis for W-1I operations to the LFABB and received approval of the document. The document was being prepared for transmittal to DOE-ORO personnel for review/approval. This document supported cleanout of the tank by the FFA program.

Entered the System Safety Analysis (WM-LGWO-7856-SSA, R0) and Technical Safety Requirements (WM-LGWO-7856-TSR, R0) documents in the WMOD Documentation Management System for controlled distribution. These documents, approved by DOE-ORO personnel, provided the authorization basis for Building 7856 (Melton Valley Storage Tanks Annex) being built by the MVST-CI Line Item Project.

\section{September}

Held a meeting with DOE-ORO personnel to discuss the LLLW System Safety Analysis Report and Technical Safety Requirements documents submitted for review/approval in Sept. 1997. DOE-ORO personnel gave preliminary indication that taking credit for Emergency Management (specifically Spill Response and Notification Programs) would not be adequate controls for a catastrophic release within the LLLW System. A week after the meeting, a letter was received from DOE-ORO personnel documenting that taking credit for Emergency Management (specifically Spill Response and Notification Programs) would not be adequate controls for a catastrophic release within the LLLW System as documented in the draft Safety Analysis Report (SAR) submitted for review/approval last year. A quick turnaround response (5 working days) was provided as requested to supply documentation to DOE-ORO personnel of other controls that are in place and a schedule for reevaluation of the accidents contained within the SAR.

Reviewed and provided comments on safety documentation for the upcoming C-tank sludge removal project.

Approved the following Unreviewed Safety Question Determination/Screening packages for inactive LLLW Tanks:

- WM-LGWO-USQDSCREEN-1998-12, Rev. 0 "USQD Change Package for Isolation of W-17 and W-18 Inlets"

- WM-LGWO-USQD-1998-11, Rev.0 "USQD Change Package for isolation/Removal of Tank W-16"

\section{October}

Completed internal approval of a page change revision for the Building 7856 Technical Safety Requirements document and transmitted the document to DOE-ORO personnel for 
review/approval. This page change addressed placing TSR level controls on a potential discharge path for LLLW to provide greater assurance that the discharge would not happen.

Received a copy of the Safety Evaluation Report and approval documentation for revision 8 of the LLLW System Operational Safety Requirements document (WM-LGWO-LLLWOSR) from DOE-ORO personnel. Personnel were beginning revisions to the affected operating procedures to implement the changes in the OSR.

Added the list of nuclear facilities to the LLLW System Operational Safety Requirements document (WM-LGWO-LLLW-OSR, Rev. 8) as required by the DOE-ORO Safety Evaluation Report recommending approval of the document. The list was then reviewed and concurred with by the DOE Facility Representative.

Approved an Unreviewed Safety Question Determination for connection of Building 7856 to the LLLW System (WM-LGWO-USQD-1998-14, R0).

Completed the annual review of the following FAB documents (no revisions were identified) and sent review documentation to DOE-ORO personnel:

- $\quad$ LLLW System Basis for Interim Operation (ORNL/WM-LGWO/LLLW/BIO/R1)

- $\quad$ LLLW System Hazard Screening (HS/LLLW/F/1/R2)

- $\quad$ System Safety Analysis for Building 7966 (SSA/7966-WMRAD/SSE/R0)

- System Safety Analysis for Out-of-Tank Evaporation System (SSA/7877WMRAD/SSE/R1)

- $\quad$ System Safety Analysis for Cesium Removal Demonstration Project (SSA/7877WMRAD/SSE-2/R0)

- Technical Safety Requirements for Out-of-Tank Evaporation System (TSR/7877WMRAD/SSE/R1)

- Technical Safety Requirements for Cesium Removal Demonstration Project (TSR/7877-WMRAD/SSE-2/R0)

- $\quad$ Building 7877 Basis for Interim Operation (ORNL/WM-LGWO/7877/BIO/R0)

- $\quad$ Building 7877 Limiting Conditions Document (WM-LGWO-7877LCD, Rev. 3)

November

Implemented the revised LLLW Operational Safety Requirements (WM-LGWO-LLLWOSR, Rev. 8) which deleted controls for tanks that have been removed from service and incorporated Building 7856 into the scope of the LLLW System.

Received the approved Technical Safety Requirements for Building 7856 (WM-LGWO7856-TSR, Rev. 1) and implemented the change to add one overflow valve to TSR level controls. This closed one pre-start activity for the Building 7856 Readiness Assessment review. 
Approved Minor Modification A to Nuclear Criticality Safety Approval 46 for the LLLW System. This added Building 7856 to the scope of facilities included in the LLLW System.

Approved the following Unreview Safety Question Determinations and Screenings:

- USQD Change Package for Connection of the New Transfer Pipeline from the Melton Valley Storage Tanks - Capacity Increase Project, WM-LGWO-USQD-199815, Rev. 0

- $\quad$ USQD Change Package for Relocation of HS-406 and HS-407 to Outside of Panel KC-02 at Building 7856 "WM-LGWO-USQD-1998-17 Rev. 0"

- $\quad$ USQD Screening Change Package for Review of Construction Interface Documents for Building 7856 "WM-LGWO-USQDSCREEN-1998-18 Rev. 0"

- USQD Screening Change Package for Contractor Interface Document Review Group 2 at Building 7856 "WM-LGWO-USQDSCREEN-1998-19 Rev. 0"

- USQD Change Package for Relocation of Process Water Flow Restrictor and Replacement of Dry-Break Connectors at Building 7856 "WM-LGWO-USQD-199820 Rev. 0"

- USQD Screening Change Package for Contractor Interface Document Review Group 3 at Building 7856 "WM-LGWO-USQDSCREEN-1998-21 Rev. 0"

- $\quad$ USQD Change Package for Inserting the Fluidic Jet-Mixer System Dummy Charge Vessel into Tanks C-1 and C-2 Risers "WM-LGWO-USQD-1998-22 Rev. 0"

- $\quad$ USQD Screening Change Package for Delete "Locked" Valve Description from SSA - Chapter 5, WM-LGWO-USQDSCREEN-1998-24, Rev. 0

December

Approved the following facility authorization basis documents for the LLLW System:

- USQD Change Package for High Level Waste Storage Tanks C-1 \& C-2, Building 2531, Installation of the AEA Technologies Fluidic Pulse Jet Mixing System, WMLGWO-USQD-1998-9, Rev. 1

- $\quad$ USQD Change Package for Installation of the Solids-Liquid Separation Module at the Melton Valley Storage Tank Facility (Building 7830), WM-LGWO-USQD-199823, Rev. 0

- $\quad$ USQD Screening Change Package for Adding Purge Air to Several Ventilation Flow Instruments, WM-LGWO-USQDSCREEN-1998-25, Rev. 0 
- $\quad$ USQD Screening Change Package for Removal of Pressure Reducing Valve PRV266, WM-LGWO-USQDSCREEN-1998-26, Rev. 0

Held a meeting with System Safety Engineering personnel to review the revised LLLW System Safety Analysis Report draft and to discuss proposed Technical Safety Requirement controls. The revision was on schedule to be submitted to DOE-ORO personnel by the end of January 1999.

\subsection{Stack Area}

$\underline{\text { January }}$

Upgrade Hot Off-Gas System at 3039 Stack General Plant Project - Completed insulation of the steam turbine and cleanup activities associated with the completion of this project. This project replaced the existing electric and steam-turbine driven blowers that supply off-gas to the main ORNL Complex in Bethel Valley with new equipment to ensure the continued reliability of this service.

\subsection{Liquid Waste Certification Official}

$\underline{\text { January }}$

Four requests were made for disposal of non-routine wastes at the Sewage Treatment Plant. Memorandums of understanding were initiated for two of these. Two of these requests were approved as well as a request from a prior month. Also initiated one new variance request for disposal of liquid waste at the Sewage Treatment Plant.

Provided assistance to three generators with wastes requiring treatment for radioactive and/or hazardous waste constituents.

Provided quarterly reports to the site Waste Certification Official. These reports are used to document the quantity of LLLW received and processed at ORNL and to assure wastes meet the WAC, or have a Variance Request approved for those that do not meet the WAC, prior to being discharged to the LLLW system.

Three variance requests were initiated for disposal of waste to the LGWO systems. All three were processed and approved.

Provided support to engineering personnel for the upcoming Surface Impoundment project. This project will remediate several ponds in the vicinity of building 3544. Assisted Engineering in evaluating items to place in their request for bid package, and were needing support to determine the Waste Acceptance Criteria requirements for the liquids generated during the project. 
The annual LLW survey was initiated. This would be completed by mid March.

Assisted WMRAD Training personnel in evaluating the training requirements for LGCOs and Generators.

\section{February}

Received a request for assistance to dispose of waste in the Sewage Treatment Plant (STP). A memorandum of understanding (MOU) was initiated and approved for this request. Also approved an additional MOU for disposal of waste to the STP that was initiated last month.

Assisted one generator in the disposal of several containers of process wastewater.

Updated a database which shows the LLW transfers to the LLW system. This update encompasses transfers for the months of December and January.

Met with WMRAD training personnel to review the training requirements for Liquid Generator Characterization Officials.

Assisted two generators by reviewing analysis of their waste streams to determine which system to discharge the waste for treatment. Initiated a variance request for another generator for waste to be disposed of in the Process Waste Treatment Complex.

Initiated one new Variance Request for the disposal of liquids into the Process Waste Treatment Complex (PWTC) - Building 3544.

Assisted another generator in the disposing of liquid wastes into the PWTC - Building 3544 from a Variance Request completed in January.

Assisted a future generator in evaluating administrative requirements that will need to be met in disposal of LLW Sludges.

Assisted one other person in evaluation of liquid wastes to determine if a Variance Request would be needed to dispose of their liquids - it was not.

Participated in the "Fourth Internal ORNL Waste Certification Program - Pilot Phase" Assessment. This assessment was being performed to help identify areas of weaknesses/strengths in the Waste Certification Program. Once identified, this information could then be used to enhance the current program. 


\section{$\underline{\text { March }}$}

Approved three Variance Request for disposal of liquids into waste processing systems at ORNL. Two of these were for disposal of liquids into the Process Waste Treatment Complex and the other was for disposal of liquids into the LLLW system.

Assisted three generators in the disposal the disposal of liquid wastes.

Reviewed assessment concerns identified during a recent Nevada Test Site (NTS) assessment with the Site Waste Certification Official (WCO) to determine the factual accuracy of identified concerns.

Developed an ORNL surveillance plan with the Site WCO.

Reviewed and commented on two training packages being developed for the ORNL Waste Certification Program.

Met with personnel from Training and the NTS Waste Certification Official to better define training needs for personnel supporting this program. The primary people requiring training to support this program were the Laboratory Generator Characterization Officials (LGCOs), the Generator Interface/Generator Interface Equivalent (GI/GIEs), and the generators. It was believed that there were areas where these positions could be combined (i.e. the LGCOs and GIEs could become one-in-the same) and, that the current training had some overlap and was giving a lot of information which provided no value added to those receiving it. Addressing these issues would be ongoing.

Performed one surveillance of a LGCO. The surveillance was performed in order to comply with requirements of ORNL-WM- 008 and to address inadequate submittal of required information.

Assisted three generators in disposing of liquids at ORNL. One of these required a variance and it was initiated. Another might require a variance request, and the generator was gathering additional characterization information to assist in making that determination. The other generator's waste was routed to the Process Waste Treatment Complex - Building 3608, and a variance was not required for it.

Continuing to collect annual surveillance submittals from LGCOs for 1998.

$\underline{\text { April }}$

Assisted seven generators with the disposal of their liquid waste. A total of six variance requests were issued and approved. One generator had an extensive number of small bottles 
of different types of liquid wastes. He was pulling together additional information so a determination could be made as to the proper disposal for these items.

Reviewed and commented on a training package being put together by the division training office to support the liquid waste certification program's training requirements.

Provided responses to close three concerns that were identified in a recent internal assessment of the ORNL Waste Certification Program.

Performed one LGCO surveillance. The surveillance was performed in accordance with requirements of ORNL-WM-008.

Surveyed all LGCOs and GIs in order to update the list of LGCOs at ORNL. This list was forwarded to WMO - Training in accordance with ORNL-WM-008, in order to assure training was given to the appropriate personnel.

Turned in the LLW Annual Surveys to Chem Tech personnel as support information for their LLW Annual Report.

Provided an updated $4^{\text {th }}$ Quarter 1997 and submitted the 1st Quarter Quarterly Reports to the ORNL Nevada Test Site Waste Certification Official.

Continued to work with two LGCOs to resolve issues discovered during recent surveillances.

Revised the list of Generators at ORNL to reflect changes which had occurred over the past year.

$\underline{\text { May }}$

Provided input (a write-up of events of LCO activities for the past six months) to Environmental Compliance personnel for their semi-annual waste acceptance criteria program report, which is submitted with the NPDES discharge monitoring report.

Approved a variance request that was received last month in early May.

Worked with a Generator Interface and the Generator in determining the proper disposal method of two liquid waste streams generated from the Life Sciences Division. One of these involved photographic wastes and the other involved some waste from a study performed on soils from Dover Air Force Base. The Generator Interface worked with the Generator to obtain analysis data on the photographic waste and the GI also worked with the Generator to determine if the Dover Air Force Base soil was RCRA prior to being received at ORNL. 
Worked with three generators to assist in disposal of their wastes. One, from the Chem Tech Division, had multiple containers of legacy wastes and he was working to obtain analytical data on them. Another generator had some newly generated waste and sent data to the LCO for determination on where it should be disposed. The other generator had some scintillation fluid and was given a Memorandum of Understanding to sign.

Assisted five other generators in the disposal of their liquid wastes. One of these required a Variance Request (VR), which was initiated last month. After resolving a concern involving a RCRA metal, the VR was approved and arrangements were made with the generator to pick the waste up from them. One had a waste stream with constituents that far exceeded the Waste Acceptance Criteria and that stream had to be rejected for disposal to the LLW system.

Initiated one variance request for the disposal of liquid wastes in the Process Waste Treatment Complex.

Attended two meetings of the Waste Certification Program Team to help resolve "statements of facts" provided during a recent DOE/BJC audit.

Obtained analytical data on zeolites generated from the SEEP C and D projects. This data was forwarded to the Generator Interface Group to prepare Process Knowledge documentation.

Performed a generator surveillance and issued a surveillance report to the Chemical and Analytical Sciences Division.

Developed a list of generators at ORNL and distributed it for review.

Added a Liquid Waste Certification Assistance web page to the LGWO Section's internal web page. Provided links to liquid waste certification documentation and the ORNL waste certification program's web page. Also provided a list of liquid waste generators and division LGCOs as well as e-mail links to all of the LGCOs. Personnel could also download WordPerfect versions of the LLLW Logsheets required to be submitted monthly.

Attended a training session related to LCO functions.

Provided remaining copies of Annual LLW Survey forms to personnel in the Chemical Technology Division for input in one of their reports.

$\underline{\text { June }}$

Completed the 2nd Qtr. FY-1998 Quarterly Report, which detailed inputs to the LLLW system, and submitted it to the ORNL Waste Certification Official. 
Assisted four generators with the disposal of their liquids. Three of these required a Memorandum of Understanding (MOUs 98-05, -06, and -07) which documented the disposal to the Sewage Treatment Plant. Both MOUs were signed off and issued. The fourth waste stream was related to waste in an FFA tank. A Variance Request (VR 98-13) was initiated, but, due to the complexity associated with this stream, there were several outstanding issues to be resolved prior to issuing it.

Assisted one generator in the development of Process Knowledge documentation for disposal of his wastes. This approach, which was suggested by the generator, would simplify his efforts yet provide assurance of being able to prove what was being discharged to the LLLW system.

Worked with one generator to dispose of a small volume of hydrogen peroxide.

$\underline{\text { July }}$

Provided assistance (on-going) to Chem Tech personnel in support of their development of the 1998 LLLW Annual Report.

Provided assistance to personnel from the Generator Interface group to help dispose of a "malt extract" solution.

Developed process knowledge package for characterization of LLLW generated at the PWTC - Building 3544.

Reviewed a draft of a new revision of the TRU - WAC and provided comments to the author.

Provided assistance to four generators for the disposal of their wastes. An MOU was initiated for one of these (MOU-98-08), and a VR was initiated for another (VR-98-15). The generator for each of these was working to complete portions of their respective document (MOU/VR). The third waste stream involved storage pool water from 7500 . Upon evaluation of the waste characteristics it was determined that a VR would not be needed to accept this waste.

August

Held discussions with the Waste Certification Coordinator and the WMOD Training Section to define training requirements for liquid waste generators. From these discussions, the Training Section would prepare Baseline Training Requirements document for the position.

Assisted. five generators with the disposal of their liquid wastes. One of these was some waste that the Hazardous Waste Operations Group (HWOG) had that they were hoping to be able to treat in the PWTC, however, it contained oils and could not be handled in the PWTC. One was for an etching solution being generated in the $M \& C$ division. A variance request was 
initiated for it (VR98-14). Another was for some waste generated as result of some Environmental Restoration work. The generator was obtaining analytical data for it. A fourth waste was one resulting from the remediation of tank W1I. Variance Request \#VR98-13 was initiated for it in June and the generator is gathering some final data so it can be completed. The last waste stream was a side stream from the photography section of the Computer Information Network Division. Assistance had been provided in dealing with Environmental Compliance personnel to help assure the waste could be disposed of in the Sanitary Sewer system.

All outstanding Liquid Certification Official (LCO) documentation which was maintained as a matter of record in support of the Nevada Test Site program was entered into the WMO Documentation Management Center.

A revised LLLW Quarterly Report was submitted to the site Waste Certification Coordinator (WCC) for the period of April through June of this year. This was done in support of the Nevada Test Site Program.

Developed a surveillance schedule for Liquid Waste Generator Characterization Officials and forwarded it to the WCC for concurrence.

Met with Quality Assurance personnel to review the closure package for items identified during surveillance NV-S-X10-98-001.

\section{$\underline{\text { September }}$}

Assisted several generators with the disposal of their liquids. Several Variance Requests (VRs) were initiated/approved in support of these disposal efforts. The following is a summary of VRs activities during the month:

VR98-13: This VR was written to cover wastewater from the W1-I tank at Building 3028. The tank is being remediated as part of the FFA program. This VR was approved.

VR98-14: This VR was written to cover wastewater generated to support research efforts from buildings $4500 \& 4515$. The waste water resulted from dissolving Stainless Steel in acid solutions. This VR was approved.

VR98-15: This VR was written to cover wastewater contaminated chemical solutions generated from chemical synthesis and HPLC solutions at building 4501. Due to the presence of certain RCRA constituents the waste could not be accepted by the LGWOS. The VR was rejected and the waste iwa being sent to the HWOG for handling.

VR98-16: This VR was written to cover wastewater generated during research efforts by the Environmental Sciences Division. It was approved. 
VR98-17: This VR was written to cover wastes generated during well water monitoring activities. It was approved.

VR98-18 was initiated to cover wastes resulting from cleaning of ER tanks W- 13 , -14 and -15 . This VR was approved.

MOU98-09, written to allow the discharge of scintillation cocktails into the Sanitary Sewer System, was approved.

Assisted a couple of generators from Metals and Ceramics. One of the waste streams was associated with the disposal of a $\mathrm{NaOH}$ solution used to clean aluminum. The other waste stream was associated with the disposal of several Fluoride containing salts. Neither of these required a variance.

Assisted a couple of generators from the Environmental Sciences Division. One of these waste steams was associated with disposal of a shampoo solution used to clean animals. The generator was gathering additional data to determine the isotopic levels in the solution. If below the Derived Concentration Guides, the solution would be able to be disposed of in the Sewage Treatment Plant. Otherwise, it would need to go to the Process Waste Treatment Complex. Their other waste stream was associated with research being conducted on constituents contained in ice bergs. It appeared at the end of the month that this would be able to be disposed of in the Sewage Treatment Plant.

A generator from the Office of Nuclear Safety had some specimens containing Opti- Flour. An MOU (MOU98-10) was written to document this disposal to the Sewage Treatment Plant.

Revised the list of liquid waste generators at ORNL and submitted the updated listed to the WMOD Training Section. The revision resulted from information obtained during a recent surveillance.

Assistance in setting up a bottling station was given to a generator from Chem Tech in building 3047 .

Training curriculum was approved for ORNL Liquid Waste - Generator Interface Equivalent personnel.

Participated in a surveillance of the Laboratory Certification Official by the ORNL Waste Certification Official.

Reviewed and commented on the ORNL Waste Certification Program Plan. 
October

Three variance requests (VR98-19, -20 and -21), which were all initiated last month were approved.

A generator from the Metals and Ceramics had an etching solution requiring disposal. After a determination from our Environmental Compliance personnel, it was decided that this waste stream met the WAC requirements and it was permitted to be discharged to the Process System.

Another generator had approximately 55 gallons of Ethylene Glycol needing disposal. An MOU (MOU98-11) was initiated to document this disposal.

MOU98-10 was approved to address the discharge of an Opti Flour solution into the Sanitary Sewer System.

A generator from Environmental Compliance had some wastes from the Well Monitoring program. It was determined that these wastes met the WAC with no additional documentation required.

Again assisted Environmental Restoration personnel by obtaining volumes transferred to the active LLLW system so they could complete their required documentation.

Provided a write-up to the Environmental Compliance group. This write-up was for use in their semi-annual report to the state on the WAC program, which was required by the NPDES permit.

Provided guidance to a generator from the Chem Tech division in regards to setting up a bottling station for LLLW waste.

Reviewed and provided comments on the Waste Certification Program Plan for the ORNL, (ORNL/TM/13288)

Variance Request \#VR98-22 was initiated and approved for a solution of waste generated by the M\&C Division.

A generator from the Energy Division requested the disposal of a waste solution containing several chemicals. Personnel from the ORNL Environmental Compliance group were evaluating this stream to determine if it complied with the ORNL WAC for Process Wastewater. 
A generator from the Environmental Sciences requested the disposal of a solution used to shampoo animals. After review of the analysis of the solution, the generator was instructed to use a process drain for the waste. No variance was required.

Provided assistance in developing responses to findings from the recent Corporate audit.

A generator from the Chemical Technology Division was assisting a generator in the disposal of some fermenters waste. He was currently obtaining additional characterization information on the waste.

One generator was working to dispose of liquid in the Sewage Treatment Plant. He resolved a couple of issues with Environmental Compliance personnel and MOU98-12 was initiated to document the disposal.

A generator from the Metals and Ceramics Division had a liquid waste solution to dispose of. Variance Request 98-22 was initiated and approved to document this disposal.

Variance Request \#VR98-23 was approved for a chemical solution generated by the Chemical Technology Division. The VR had been forwarded to Environmental Compliance personnel for evaluation before approval.

Assisted one generator from the Energy Division. He had some waste which contained a small concentration of Lithium. The state TDEC was contacted to assure this would be acceptable.

Assisted another Chem Tech generator who had some waste containing Chromium. She was in the process of providing analytical data on the waste stream.

Assisted one generator from Environmental Sciences who had several waste solutions. Two of these were high in Chromium. The others appeared to be acceptable for the Process Waste System.

Assisted one generator from Environmental Restoration. He had 5,000 gallons of waste which needed to be trucked to the Process Waste Treatment Complex from the WAG 5 project.

Assisted a Generator Interface person having a small solution which was sent to the Sewage Treatment Plant.

MOU98-13 was written and approved for the disposal of an Ethylene Glycol solution to the Sewage Treatment Plant. 
MOU98-14 was initiated to dispose of an antifreeze solution in the Sewage Treatment Plant. The generator was acquiring a required generator signature on the MOU.

Met with a Liquid Waste - Generator Interface Equivalent (LW-GIE) person representing the Metals and Ceramics Division to review characterization information on a waste they were wanting to dispose of. Upon review of this information, it was determined that no VR was needed and the waste could be poured down a local drain. This would be an ongoing stream and the generator was instructed to maintain a close watch on the iron concentration as it was close to the WAC limits.

A VR (VR98-24) was initiated for an Environmental Sciences researcher. The waste was being generated as a result of some research work being done to analyze the uptake of mercury by algae growth in water. The VR received a couple of the required approval signatures and was currently being evaluated by Environmental Compliance personnel for approval.

VR98-25 was initiated for another Environmental Sciences having small concentrations of cadmium and chromium. The VR was also currently being evaluated by Environmental Compliance personnel for approval.

Discussed the possibility of taking some waste containing Isopropanol from a generator in Building 3047. Due to the potential flammability issue associated with this, fire protection personnel were contacted to assure their concurrence with disposal of this stream. They agreed it is ok and a VR would be initiated for this.

Discussed the possibility of allowing a RCRA D001 waste being discharged to the Sewage Treatment Plant. Although the STP is a technically suitable place to treat this type waste, it was determined that RCRA regulations prevented this from occurring.

A VR was initiated for a Chemical Technology generator who was doing some research on a waste received from off-site. ORNL permits forbid the acceptance of treatment of wastes from off-site; therefore, the variance was denied prior to being assigned a number.

Received two Memorandums of Understanding (MOU98-12 and -11) from generators. Both of these had been initiated a couple of weeks ago. The generator for MOU98-11 was requested to provide characterization information on the waste, so it was still pending. MOU98-12 was forwarded onto the STP facility manager for his approval.

Presented several sessions of the Generator Interface Training Module to Liquid Waste Generator Interface Equivalent (LW-GIE) personnel. At the conclusion of this training a memo was sent to the Laboratory Waste Certification Official informing him that all LW- 
GIEs had been trained. This closed a nonconformance report which had been written to document the incomplete training of LW-GIEs.

Updated the LW-GIE list and forwarded to the WMOD training section.

Prepared a quarterly report and sent it to the Laboratory Waste Certification Official in accordance with requirements in ORNL-WM-008.

Began a revision to two liquid waste certification documents. The documents were ORNLWM-008 and WM-LWS-WAC. The revisions were being performed as part of an ongoing review of the Liquid Waste Certification program.

Performed a LW-GIE surveillance (\#NV-S-X10-98-006) from a generator in the Metals and Ceramics Division, Building 3025E. There were no findings from this surveillance. It was noted that the operations associated with this LW-GIE were "Good support to the ORNL Liquid Waste Certification Program."

Completed drafts of revisions to the WAC and to the implementing procedures for the Liquid Waste - Waste Certification Program.

Met with the ORNL Waste Certification Program Team and discussed the need of Liquid Wastes remaining under the purview of the ORNL Waste Certification Program Plan. It was decided that it should be operated separately.

\section{November}

Met with Environmental Compliance (EC) personnel to discuss Variance Request (VR) \#9824. This waste stream contained a very small concentration of mercury, which although was below RCRA limits, it went against an agreement with the state which only allowed the treatment of small concentrations of "legacy" mercury. EC sent an email to LMER lawyers to try to get some guidance on this VR.

VR \#98-25, which was written last month for disposal of some Environmental Sciences wastewater, was approved. An additional calculation to show a worst case scenario of RCRA metals concentration was performed to assure the sludges generated from treatment of this waste would not render it RCRA.

VR \#98-26, which was initiated for the upcoming AEAT work which will mobilize the sludge in the C-1 and -2 tanks, was approved.

VR \#98-27 was initiated for waste water resulting from the earlier Insitu Vitrification project. The VR was with Environmental Compliance personnel for review. 
VR \#98-28 was initiated for a new waste stream from the HFIR. The VR was rejected due to the significant flow it would add to the PWTC.

Memorandum of Understanding (MOU) \#98-11, which was written for the disposal of some ethylene glycol in the Sewage Treatment Plant, was still awaiting characterization data from the generator.

MOU \#98-12, which was written for the disposal of some fermentation microorganisms, was approved.

MOU \#98-14, which was written for the disposal of some antifreeze solution which would be generated over the winter, was initiated and approved.

Reviewed analytical data provided by personnel from the HFIR for waste water they wanted to send to the LGWO section for disposal. It was found to be acceptable for the LLLW system.

Provided assistance to a generator interface person working the Environmental Restoration group to get rid of numerous small quantities of waste. From a list of over 400 items an initial determination was made as to which of these could go to the STP for disposal. Environmental Compliance personnel were reviewing this list to make sure that those items identified were permissable to go to the STP.

Assisted another Generator Interface person working with the Office of Radiation Protection to dispose of approximately 25 liters of LLLW.

Met with Environmental Compliance and ORNL and DOE legal personnel to review the mercury limit for wastes discharged to the PWTC-3608 system. It was determined to send a letter to the state requesting them to consider allowing discharges of "newly generated" mercury containing wastes when it could be shown that the mercury levels would not result in an environmental insult. This was being done to address the issues associated with Variance Request (VR) \#VR98-24. A calculation was performed to show that the discharge from this particular waste stream would be $<2.25$ parts per trillion.

Reviewed sample analysis results for two waste streams generated at the HFIR. It was determined that no VR was required for these streams and arrangements were made with the generator for the LGWO to pick up the wastes.

A generator from the Metals and Ceramics Division requested to use old process knowledge documentation while new documentation was being developed by the WMO Generator Interface Group. Permission was given to do this. 
Assisted a generator working with the Environmental Restoration group who had some rain water that had collected in tank W-11. After reviewing analytical data it was determined that the waste could be disposed of in the PWTC without the generation of a VR.

Support provided to generators to dispose of their wastes also included working with personnel from the Hazardous Waste Operations Group in evaluating a drum of waste for possible disposable in the Process Wastewater Treatment System. Due to uncertainty about the contents of the drum (i.e. whether all constituents were mixed together in the drum or whether they were individually containerized within the drum) more investigation was being performed prior to taking the waste.

Incorporated additional comments into drafts of the Waste Acceptance Criteria (WAC) and implementing procedures for the Liquid Waste - Waste Certification Program. Also, discussed the scope of the changes being implemented in the implementation procedures with the Laboratory Directives and Guidance Head. These were being considered to determine if they required additional distribution and review. At the end of the month the document was signed by the preparer and was approved by the LGWO Section Head and by the WMO Division Director.

Reviewed and provided comments on WACs for the Sewage Treatment Plant and the Coal Yard Runoff Treatment Facility.

Reviewed data provided by generators and performed fissile conversion calculations to check on adherence to nuclear criticality requirements. All were found to be within the necessary range.

Received approval from the Laboratory Directives and Guidance Head for a revision to the ORNL Liquid Waste Implementation Plan (ORNL-WM-008). The document was then signed by the preparer and by the WMO Division Director. It was at Dr. Swank's office awaiting his approval at the end of the month.

Submitted documentation to the WMO Documentation Section in support of the ORNL Liquid Waste Certification Program. The documentation consisted primarily of approved variances, Liquid Low-Level Waste Log Sheets, and surveillances.

Provided interface and support throughout the week during the Nevada Test Site Audit.

Made final arrangements for training for Liquid Waste Generators at ORNL. Performed the first training session on November $23^{\text {rd }}$ and will continue holding sessions throughout December. Over recent times it was determined that the training requirements for generators could be changed and consolidated. This training session was a result of that determination. 


\section{December}

Continued with support of Variance Request (VR) 98-24. A memo was prepared by Environmental Compliance personnel to request permission from the state to allow the waste identified in VR98-24 to be discharged into the ORNL PWTC. The waste contained trace amounts of mercury. The concentrations were significantly below RCRA limits; however, since the current understanding with the state was that no "newly generated" mercury would be discharged into the system, additional input from the state was being requested.

Initiated VR98-29. The variance was initiated to allow the discharge of wastewater containing some volatile organics. Concurrence to allow this discharge from ORNL Fire Protection personnel was given. The generator had the VR and was getting the appropriate signature on the variance from within his organization at the end of the month.

VR98-27 received final approval. It was written to allow for the discharge of waste waters originating from the Insitu-Vitrification project. The wastewater contained minute quantities of "legacy" mercury.

VR98-14 was revised to allow for an increase in the discharge quantity described in the original request.

Approval of Memorandum of Understanding (MOU) \#MOU98-16 was received by Environmental Compliance personnel to allow for the discharge of numerous small quantities of various waste waters into the STP. Upon this approval, the generator agreed to go back and determine the exact quantities of each constituent allowed in the MOU.

A request for the generator of MOU98-11 to provide the concentration of ethylene glycol was made during the month. After receiving this information, the STP facility manager was able to plan for proper disposal of the liquid.

Personnel from the HFIR requested a pick-up of LLLW from their facility. Upon review of analytical data from the wastewater, it was determined that the liquid could be disposed of as LLLW.

Continued working with personnel from the HWOG in evaluating a drum of waste for disposal in the Process Waste Treatment System. It was determined that one of the 55 gallon drums actually contained several individual containers. The contents of these containers were being evaluated to determine their suitability for disposal in the PWTS.

Initiated Variance Request (VR98-30) to allow the discharge of approximately 80 gallons of legacy waste into the ORNL LLLW system. The variance was in review. Concerns were voiced by Environmental Compliance personnel and they were being addressed to determine if it would be acceptable to send the waste to the LLLW system. 
Received a request from the Liquid Waste - Generator Interface Equivalent in the Environmental Sciences Division to allow disposal of two carboys of waste into the PWTC3608. Upon review of characterization information for the wastes, it was determined that one carboy could be discharged into an existing PWTC-3608 drain and that the other would have to be picked up and taken to the PWTC-3544.

Continued interface with Environmental Compliance personnel in trying to determine if the waste identified in Variance Request \#VR98-30 was suitable for disposal in the ORNL LLLW system. At the end of the month personnel were finalizing a review of the permit to determine if this would be acceptable.

Reviewed and provided comments on a revision to ORNL procedure \#ORNL-WM-106.10.

Three training classes were performed for Liquid Waste Generators at ORNL.

\subsection{Miscellaneous}

January

Approved one Document Change Directive (WM-LGWO-608.13R1-DCD2) for operation of the Out-of-Tank Evaporation System.

Approved revisions to the following procedures to allow the usage of tank W-21 as an evaporator feed tank: WM-LGWO-610.2.1 R15 and -610.2.6 R7.

Approved a revision to the Out-of-Tank Evaporation System procedure (WM-LGWO-608.13 Rev. 2).

Approved revisions to the Shift Turnover Procedure (WM-LGWO-606.2 Rev. 8) and the Melton Valley LLLW System procedure (WM-LGWO-610.2.3 Rev. 10).

Reviewed and provided comments on a draft ORNL procedure titled "Compliance with the Clean Air Procedure" to ensure it met the Work Smart Standards recently approved for ORNL WMRAD facilities and activities.

Began preparation of the LGWOS Annual Report for Calendar Year 1997 operations. A rough draft should be issued for review in early February.

\section{February}

Reviewed and commented on nine procedures and two guides in support of the "Necessary and Sufficient" program at ORNL. 
Provided a quick turnaround response for information on documentation for LGWOS' nuclear facilities to Bechtel-Jacobs personnel. Questionnaire primarily dealt with the facilities' authorization basis and operational history. Met with Bechtel-Jacobs personnel two working days later to discuss the questionnaires. After a review of the information, a $1 / 2$ day tour of LGWOS nuclear facilities was provided. Personnel were very complementary of the status of LGWOS facilities. LGWOS personnel also provided a hard-copy of the completed questionnaire as well as a cleaned-up electronic file of the questionnaire to Solid Waste Operations Section to assist them in their preparation of responses.

Completed the LGWOS Annual Operating Report for CY 1997 (ORNL/TM-13581) and began signout for external release. This report was a Performance Tracking System (PTS) milestone for ADS3201 and 3251 and was required to be issued by March 31, 1998.

Met with personnel from the TDEC to discuss removal efficiencies of the Process Waste Treatment Complex. Presented the results of a special sampling and analysis project to support this effort to the TDEC.

\section{$\underline{\text { March }}$}

Transmitted the LGWOS Annual Operating Report for CY 1997 (ORNL/TM-13581) to Laboratory Records for reproduction and distribution. This completes a PTS milestone for ADS3201 and 3251 that required the report to be issued by March 31, 1998.

Cancelled twelve Quality Assurance Plans and Functional Requirement Documents for completed line items and general plant projects.

Cancelled the LGWO Solid Waste Certification Procedure (WM-LGWO-606.8).

Reviewed and provided comments on two procedures in support of the "Worksmart Standards" program.

Revised ten LGWOS operating procedures during the month: WM-LGWO-609.2.1 Rev. 20 (WOCC Operator Duties), WM-LGWO-610.2.1 Rev. 16 (Bethel Valley LLLW System), WM-LGWO-604.2.5 Rev. 13 (Filter Press Operations at Building 3608), WM-LGWO608.13 Rev. 3 (OTE Operations), WM-LGWO-603.2.2.1 Rev. 3 (Bethel Valley Influent Pumping Station), WM-LGWO-606.6 Rev. 3 (Standing Orders), WM-LGWO-603.2.1.2 Rev. 5 (Building 7961 Caustic Metering System - editorial change), WM-LGWO-609.2.3 Rev. 2 (System Administration for the Waste Operations Control Center's Data Acquisition System), WM-LGWO-604.2.11 Rev. 11 (Building 3608 Analytical and Sampling Procedures), and WM-LGWO-604.2.12 Rev. 2 (F-1006 Clarifier System Operation).

Issued a Document Change Directive for Out-of-Tank Evaporation System Operations: WMLGWO-608.13R3-DCD1. 
Met with personnel from the $P \& E$ division to go over plans for a parking lot being installed on the North end of building 2101; and, met with personnel from Chem Tech to go over plans to do some video work in the C-1 tank located at building 2531 .

Met with Plant and Equipment personnel to look at the new parking lot to be placed at the north end of Building 2101 (LGWO Changehouse). This parking lot was being installed to alieviate safety concerns associated with the current parking lot that were identified through the LGWOS Performance Measurement Team (PMT) program.

April

LGWOS personnel assumed responsibility for the LGWOS internal web pages. Completed the following activities:

1) Revised several facility pages to reflect changes made in the past six months,

2) Made approximately 100 pages of LGWOS facility drawing lists available for maintenance and Engineering personnel to use (lists are of controlled drawings maintained by LGWOS),

3) Installed detailed fact sheets for the primary systems and facilities under LGWOS control,

4) Added monthly and yearly summaries of treatment facility operations for calendar years 1993, 1994, 1995, 1996, and 1997.

5) Revised the LGWOS home page to support a frames-based menu structure,

6) Added a LGWOS contact page providing telephone, pager, and e-mail information for all LGWOS personnel, and

7) Added monthly and yearly summaries of rainfall data for the years 1989-1997.

Approved entry of the following drawings into the WMO Procedures and Data Services (PDS) group for controlled distribution: 1) Building 30921996 Upgrades Instrumentation Drawings (initial entry), 2) Building 7877 Piping and Piping and Instrumentation Diagram Drawings (revision 3), and 3) Building 7966 Instrumentation Drawings (initial entry).

Completed the 2-year review of several LGWOS operating procedures. Based on the review comments, the following revisions were approved for entry into the WMO PDS for controlled distribution: two procedures for operations in the Process Waste Collection and Transfer System (WM-LGWO-603.4.1 Rev. 3, -603.4.3 Rev. 4); three procedures for operations at Building 3608 (WM-LGWO-604.3.1 Rev. 3, 604.3.4 Rev. 6, -604.4.2 Rev. 4); one procedure for alternate process waste storage (WM-LGWO-607.2 Rev. 3); and two procedures for operations in the 3039 Stack Area (WM-LGWO-612.2.6 Rev. 6 (revised to incorporate a Document Change Directive), -612.2.7). Three procedures in the Process Waste Collection and Transfer System were found to require no revisions during this review (WM-LGWO-603.3.1 Rev. 2, -603.3.5 Rev. 3, and 603.4.2 Rev. 1). 
Approved a revision to one LGWOS procedure for operations at the LLLW Evaporator Facility (WM-LGWO-611.2.1 Rev. 5).

Approved a revision to the Melton Valley Storage Tanks operating procedures (WM-LGWO-610.2.4 Rev. 6) for controlled distribution.

Approved administrative guides documenting requirements of the Building 3544 air permit (WM-LGWO-ADMIN-4) and the Building 3039 air permit (WM-LGWO-ADMIN-5).

Approved the following two Document Change Directives for LGWO operations during the month: 1) WM-LGWO-610.2.1R16-DCD1 for operation of the new transfer system from Building 3025E to the Central Waste Collection Header; 2) WM-LGWO-608.13R3-DCD2 for Out-of-Tank Evaporation operations.

Added approximately 70 digital photographs and proof-sheets of LGWOS facilities to the LGWOS Web Page for easy reference by other personnel.

$\underline{\text { June }}$

Approved the revision to the LGWO Section Quality Assurance Plan (QAP-X-91WMRA/WM-027, Rev. 4). This revision was made to reflect changes in the Division's organizational structure and other changes from the WMOD Management Plan.

Approved a revision to the Granular Activated Carbon Columns operating procedure (WM-LGWO-604.2.8, Rev. 8) based on minor comments received during the procedure's 2-year review.

Approved a Document Change Directive for the Out-of-Tank Evaporation System's procedures (WM-LGWO-608.13R3-DCD2) to add additional HP requirements during collection of samples at the pump module sampler. This was to close a corrective action associated with a recent occurrence report.

Approved several revised entries of LGWO Drawing Series to the Procedures and Data Services Group for controlled distribution: 1) Valve Box on the Southwest Side of Building 3026, 2) Building 2099 Instrumentation Drawings, 3) Building 2531 Instrumentation and Controls Division generated Drawings, 4) Evaporator System A2 Instrumentation Drawings, 5) Bldgs. 2531 (Evaporator System 2A2) and 2537 Instrumentation Drawings, 6) Building 3608 Piping and Instrumentation Diagram Drawings, 7) Building 7830 Instrumentation Drawings, 8) Building 2099 Instrumentation Drawings, 9) Building 2099 Piping Drawings, 10) Building 3608 Electrical Drawings, and 11) Building 3608 Instrumentation Drawings. Also approved baseline entry of the following drawing series: 1) Building 2649 Electrical 
Redlined Drawings, 2) Building 2649 Instrumentation Redlined Drawings, 3) Building 2649 Piping Redlined Drawings, 4) Building 2649 Architectural Drawings, 5) Building 2649 Mechanical Drawings, 6) Building 2649 Structural Drawings, 7) Building 2649 Ventilation Drawings, and 8) F-2175 Hot Off-Gas Condensate Collection Tank Drawings.

Approved revisions of $15 \mathrm{LGWO}$ conduct of operations guidelines based on the revised work smart standards to be issued at ORNL on July 6.

$\underline{\text { July }}$

Approved revised Architectural, Civil and Structural engineering drawings for the PWTC - Building 3544 for controlled distribution.

\section{$\underline{\text { August }}$}

Approved a Document Change Directive for Ventilation Operations at the LLLW Evaporator Facility. This provides instructions for operation of the new aboveground filter pit being installed at the facility.

Completed the 6-month review of administrative control tags in usage at LGWOS facilities.

\section{September}

Approved the following revisions to two procedures to delete inactive tank WC-2 (which was recently filled with grout by the FFA Program):

WM-LGWO-609.2.1, Rev. 21 "Waste Operations Control Center Operator Duties" WM-LGWO-610.2.1, Rev. 17 "Bethel Valley LLLW System"

Approved a revision to procedure WM-LGWO-606.2, Rev. 9 "Shift Turnover Procedure" due to a revision in the shift turnover check sheet for the Process Waste Treatment Complex - Building 3608.

Approved revisions to the following five procedures for operations in the 3039 Stack Area (editorial changes to update facility contact/phone lists):

WM-LGWO-612.2.1, Rev. 7 "ORR Cell Ventilation System Operation" WM-LGWO-612.2.2, Rev. 8 "3500 Area Cell Ventilation System Operation" WM-LGWO-612.2.3, Rev. 8 "4500 Area Cell Ventilation System Operation" WM-LGWO-612.2.4, Rev. 7 "3025/3026 Cell Ventilation System Operation" WM-LGWO-612.2.5, Rev. 7 "Isotope Area Cell Ventilation System Operation" 


\section{$\underline{\text { October }}$}

Approved revisions to two procedures in support of Process Waste operations. The procedures were WM-LGWO-604.2.7 and -603.3.2.

Cancelled procedures WM-LGWO-608.8, WM-LGWO-608.9, and WM-LGWO-608.10 for various leak testing activities that had been performed by the FFA leak testing program after the program's personnel notified LGWOS that the procedures were no longer necessary.

\section{November}

Approved revisions to the following procedures and submitted them to WMOD PDS for controlled distribution:

WM-LGWO-609.2.1 Rev. 22 "WOCC Operator Duties" WM-LGWO-610.2.1 Rev. 18 "Bethel Valley LLLW System" WM-LGWO-610.2.9 Rev. 1 "Building 7856 Operations" WM-LGWO-610.3.6 Rev. 1 "Building 7856 Utility Systems" WM-LGWO-610.2.3 Rev. 11 "Melton Valley LLLW System" WM-LGWO-610.6 Rev. 4 "Record Management and System Documentation for the LLLW and PW Collection and Transfer Systems"

WM-LGWO-602.2.6 Rev. 6 "Acid Fume Scrubber at Building 3544"

\section{December}

Approved the following revisions to LGWOS controlled documents:

"Transfers to the MVST Facility Procedure" WM-LGWO-611.2.6 Rev. 6

"Record Management and System Documentation for the LLLW Evaporator Facility" WM-LGWO-611.6, Rev. 4

"LGWO Administrative Guide - Nuclear Criticality Safety Approval for the Active LLLW System (ID No. 46) Implementation" WM-LGWO-ADMIN-1, Rev. 1

"LGWO Administrative Guide - Building 3544 Air Permit" WM-LGWO-ADMIN-4, Rev. 1

Approved a Document Change Directive for the Melton Valley Storage Tanks Facility (WMLGWO-610.2.4R6-DCD1) procedure.

Approved the following drawing collections for controlled distribution:

Building 2568 - Piping and Instrumentation Diagrams, Rev. 0

Building 7856 - Instrumentation Drawings, Rev. 0 
Building 2101 - Architectural, Civil, Electrical, HVAC, Piping, and Structural Drawings, Rev. 0

Building 7856 - Architectural Drawings, Rev. 0

Building 7856 - Civil Drawings, Rev. 0

Building 7856 - Electrical Drawings, Rev. 0

Building 7856 - HVAC Drawings, Rev. 0

Building 7856 - Mechanical Drawings, Rev. 0

Building 7856 - Piping Drawings, Rev. 0

Building 7856 - Piping and Instrumentation Diagrams, Rev. 0

Building 7856 - Structural Drawings, Rev. 0

Provided an annual review/update of the Stack and Vent Survey for LGWOS facilities.

Assisted the Division Safety Officer in identifying multiple electrical feeds for Building 3130. After reviewing drawings for the building, two multiple feeds that would be of concern should maintenance have to perform an electrical lockout were identified and posted per requirements.

\subsection{Configuration Control}

During the year, three changes were classified as meeting the requirements of a Configuration Change. In addition, nine changes to LGWO facilities had been classified as meeting requirements of an Equipment Change (a change that does not meet the ORNL definition of a Configuration Change, but which the LGWO has determined should be documented). 


\subsection{MAINTENANCE ACTIVITIES}

3.1 Process Waste Treatment Complex (Buildings 3544 and 3608) and Collection System $\underline{\text { January }}$

Repaired a seal on pump L-11 and a valve that was leaking through on the new transfer line from the LLLW concentrate storage tank to the tanker loading area at the Process Waste Treatment Complex - Building 3544.

Provided support to P\&E personnel at the Melton Valley Process Waste Collection Tanks Facility (Building 7961) who repaired a failed transfer pump (J-2016B) and an automatic valve on the waste inlet line from Building 7900 .

\section{February}

Repaired a pin hole leak in a flange weld on the discharge line from sulfuric acid pump J$1026 \mathrm{E}$ at the Process Waste Treatment Complex - Building 3608. This pump supplied acid to lower the $\mathrm{pH}$ in tank F-1050 prior to pumping the wastewater to Building 3544 for further treatment.

Replaced the L-9 acid pump and cleaned out its transfer line. This pump was used to provide feed to the L-10 nitric acid recovery evaporator at the Process Waste Treatment Complex Building 3544.

March

Completed a piping modification at Building 3544 to allow the discharge from the ionexchange system to go directly to the F-4004 wetwell and bypass the L-5 clearwell.

Repaired the sump pump for the chemical unloading area at the Process Waste Treatment Complex - Building 3544.

Installed a flush line on the polymer addition line to the F-1007 clarifier at Building 3608 . This flush line allowed personnel to flush the line after batch processing of metals wastewater is completed (this would help prevent plugging of the line due to residual polymer between batch operations).

Repaired a leak on the J-1026D acid pump at the Process Waste Treatment Complex Building 3608 . This pump was used to adjust the $\mathrm{pH}$ of the softened wastewater prior to transfer to Building 3544 for radiological treatment. 
Repaired a oil leak on the L-12 scrubber pump at the Process Waste Treatment Complex Building 3544.

Performed operational tests of all equipment associated with tank F-2103 at Building 2600 (Bethel Valley Process Waste Collection Tanks Facility). This tank was used to provide additional storage capacity during periods of heavy inflow to the Process Waste Collection System.

Prepared four of the MC-307/312 process waste tankers (5,000 gallon capacity each) for their annual Department of Transportation inspection.

Completed a pressure decay test on the process waste line in the Process Waste Treatment Complex that begins at the F-4004 wetwell (located at Building 3544) to Building 3608 . The line held a pressure of $110 \mathrm{psig}$ for a minimum of 4 hours. This test was conducted as part of an ongoing effort to identify the sources of contamination inflow to seeps along White Oak Creek.

Completed the quarterly inspection of LGWOS diked areas.

$\underline{\text { April }}$

Removed pump J-1006B from service to repair a leaking seal at the Process Waste Treatment Complex - Building 3608. This pump was used to recycle sludge from tank F-1006 to F1070.

Repaired pump J-4001A at the Influent Pumping Station (F-4001). This pump was one of three pumps used to transfer process waste from the main ORNL complex in Bethel Valley to the Process Waste Storage Tanks at Building 2600.

Replaced two acid pumps (J-1026D and J-1026E) at Building 3608.

May

Cleaned out the transfer line from the F-1025 sulfuric acid storage tank to the loading/unloading station at the Process Waste Treatment Complex - Building 3608.

Completed repairs of the J-2019 Jet Mixer at the Melton Valley Process Waste Collection Tanks (Building 7961). The jet mixer had been tripping. The jet mixer was used to keep any particulates in the wastewater suspended until transferred to Bethel Valley for future treatment.

Cleaned out debris from the main diked area sump at the Process Waste Treatment Complex - Building 3608. 
$\underline{\text { June }}$

Cleaned out the piping between tanks F-1060 and F-1070 at the Process Waste Treatment Complex - Building 3608 . The pipe had become partially plugged and was preventing the design flowrate of $300 \mathrm{gpm}$ to $\mathrm{F}-1070$ being achieved.

Repaired the sulfuric acid feed system at Building 3608 to tank F-1050. This acid was used to adjust the $\mathrm{pH}$ of the wastewater prior to transfer to the radiological treatment process at the Process Waste Treatment Complex - Building 3544.

Repaired the F-1006 sludge rake and removed excess sludge out of the F-1006 clarifier at the Process Waste Treatment Complex - Building 3608. Repairs were made after the gear drive on the rake had broken.

$\underline{\text { July }}$

Completed the monthly test of the steam turbine-driven pump at the Influent Pumping Station (F-4001). This pump provided backup service in case of failure of the two electrical pumps used to transfer process waste from Bethel Valley operations to the Bethel Valley Process Waste Storage Tanks (Building 2600).

Completed repairs to the J-4005A pump at the Metals/Nonmetals Pumping Station (F-4005).

Completed the following activities at the Process Waste Treatment Complex - Building 3608:

- Repaired an electrical problem associated with the filter press.

- Received one load (approx. 2,200 gallons) of sodium hydroxide (caustic) in the bulk storage tank at the facility. Caustic was used to adjust the $\mathrm{pH}$ of wastewater at the facility to assist in the water-softening operations.

- Transferred one load of sulfuric acid from the bulk storage tank at Building 3608 to the Process Waste Treatment Complex - Building 3544. The acid was used to adjust the $\mathrm{pH}$ of the wastewater at Building 3544 prior to transfer to Building 3608 for further treatment.

- Transferred 2 loads of caustic from the bulk storage tank at Building 3608 to the Melton Valley Process Waste Collection Tanks Facility (Building 7961). The caustic was used to maintain the wastewater at a basic $\mathrm{pH}$ until transferred to Bethel Valley for future treatment.

- Completed repairs to the filter press system

- Completed repairs to the J-1026D\&E sulfuric acid pumps used to adjust the pH of the water-softened wastewater prior to transfer to Building 3544 for radiological treatment

- Repaired the clarifier system used for water-softening operations of radiologically contaminated wastewater.

- Completed repairs to the J-1026A and J-1006 pumps. 
- Completed the quarterly acid cleaning of the air stripper to remove growth from the packing media and to prevent disease growth within the tower.

- Transferred one load of sulfuric from the storage tank at Building 3608 to the Process Waste Treatment Complex - Building 3544 for use in adjusting the $\mathrm{pH}$ of the wastewater prior to transfer to Building 3608 for further treatment.

- Transferred one load of sodium hydroxide from the storage tank at Building 3608 to the Melton Valley Process Waste Collection Tanks Facility (Building 7961) for use in maintaining the process waste at a basic $\mathrm{pH}$ prior to transfer to Bethel Valley for treatment.

Completed repairs to the seals on the L- 8 transfer pump at the Process Waste Treatment Complex - Building 3544.

Completed DOT testing and inspection of the acid/caustic tanker truck.

\section{$\underline{\text { August }}$}

Completed the following activities at the Process Waste Treatment Complex - Building 3608:

- Replaced the bearings on the air stripper blower.

- Transferred one load of sodium hydroxide from the storage tank at Building 3608 to the Melton Valley Process Waste Collection Facility (Building 7961).

- Replaced a failed check valve on the air stripper acid addition line at the Process Waste Treatment Complex - Building 3608. The check valve prevented water from entering the acid addition system at the facility.

- Transferred the sludge from the F-1006 Clarifier at the Process Waste Treatment Complex - Building 3608 in preparation for maintenance activities on the clarifier. The clarifier was used to soften wastewater prior to further treatment.

Replaced the bypass piping for the flow meter at the Bethel Valley Process Waste Storage Tanks (Building 2600) after the existing pipe developed a small leak at the $T$ connection.

Completed repairs to the diversion valve at Manhole 208.

Repaired an acid leak in the ion-exchange column room at the Process Waste Treatment Complex - Building 3544.

Completed quarterly dike inspections at all Process Waste System Facilities.

\section{September}

Completed the monthly testing of the pumps and valves associated with the million gallon storage tank at Building 2600 (Bethel Valley Process Waste Storage Tanks). This tank and 
associated equipment provided additional storage capacity for the Process Waste System during periods of heavy inflow to the system.

Cleared the plugged sludge recycle line for the F-1006 clarifier at the Process Waste Treatment Complex - Building 3608.

Replaced the air conditioner for the Process Control Unit at Building 7961 (Melton Valley Process Waste Collection Tank Facility) after it failed.

Repaired the L-P2 pump motor at the Process Waste Treatment Complex - Building 3544 after the motor was found to be tripping.

Installed a temporary hand operated valve for valve FCV-636 at the Process Waste Treatment Complex - Building 3608 to allow personnel to backwash the F-1019 Granular Activated Carbon column. A new remote operated valve was on order and would be installed upon receipt.

\section{October}

Replaced two valves (HV-125 and HV-126) at the Process Waste Treatment Complex Building 3608 due to broken valve operators.

Replaced the air release valve located on top of the F-1009 dual-media filter at the Process Waste Treatment Complex - Building 3608 after the valve was found to not be seating properly after filter backwashing.

Completed repairs to the L-9 transfer pump at Building 3544. This pump had developed a leaking seal.

Updated an Excel spreadsheet database used to trend performance of the Ion Exchange Columns at the Process Waste Treatment Complex - Building 3544. This was used to provide early indication to LGWOS personnel when the ion-exchange resin in a column might need replacement.

Completed monthly operational test of the transfer pumps at Building 2600 (Bethel Valley Process Waste Storage Tank Facility) that were associated with tank F-2103.

\section{November}

Replaced pump L-10 and completed preparation activities for installing a new man way on the L-3A polishing filter at the Process Waste Treatment Complex - Building 3544. 
Replaced the J-1026C sulfuric feed pump at the Process Waste Treatment Complex Building 3608 .

Began installation of the replacement access manhole on filter L-3A at the Process Waste Treatment Complex - Building 3544. This replacement provided easier access to the interior of the vessel for maintenance activities.

Performed the monthly functional test of the pumps for tank F-2103 at the Bethel Valley Storage Tanks (Building 2600).

Received one tanker load of sulfuric acid at the Process Waste Treatment Complex Building 3608. This acid was used to adjust the $\mathrm{pH}$ of the wastewater prior to discharge to White Oak Creek.

Completed the quarterly dike inspections throughout LGWOS facilities.

\section{December}

Completed the quarterly sulfuric acid wash of the air stripper tower's. This removed algae buildup on the packing and helped control bacteria growth in the stripper.

Replaced two valves that had leaked thru in the acid transfer system from the chemical unloading station.

Cleaned out the transfer line from tank F-1060 to F-1070 after the line had become plugged due to the water-softening chemicals added in mixing tank F-1060.

\subsection{Liquid Low-Level Waste System}

January

Repaired a leaking fitting on the annulus monitoring system for the transfer line from Building 2099 (Monitoring and Control Station for Building 2026) to Valve Box 1A (Building 3133).

Repaired a faulty level probe in Valve Box $1 \mathrm{~B}$.

\section{February}

Entered the pump and valve vault at Building 7966 (Monitoring and Control Station for the REDC) to repair a short circuit in the cathodic protection system. Several bolts at the cathodic isolation point were replaced, but a short circuit was still detected across the flange. 
Engineering personnel then requested LGWOS personnel to replace the gasket at the flange in the near future in an attempt to repair the problem.

Performed repair work inside Valve Box $1 \mathrm{~A}$ (Building 3133) to assist construction personnel installing a new transfer pipeline from Building 3025E.

Repaired a failed valve for steam jet J-4 at the LLLW Evaporator Facility (Building 2531). This steam jet was used to transfer LLLW feed from evaporator feed tank A-1 to evaporator vessel $\mathrm{A}-2$ for volume reduction.

$\underline{\text { March }}$

Completed repairs to the cathodic isolation point at Building 7966 (Monitoring and Control System for the REDC Complex). Personnel replaced the isolation gasket and other parts of the isolation kit to resolve a short circuit that could lead to a substantial decrease in the life of the sacrificial anodes for the system. At the end of the month Engineering personnel were taking readings on the system to determine if the repairs had been successful in meeting the cathodic protection system's design requirements.

Completed removal of construction debris at Building 2537 that was left behind by the Bethel Valley FFA Line Item Project that replaced the instrument cabinets and installed a new steam control station at the facility last year.

Supported effort to film the insides of tanks C-1 and C-2 and performed measurements to support providing an accurate level reference for the new level monitoring equipment that was to be installed on the tanks.

$\underline{\text { May }}$

Repaired stops on two valves at Building 7830 (Melton Valley Storage Tanks Facility).

Repaired the sump level probe at Valve Box 1B after it was discovered that water was getting into the wiring conduit and giving a false detection signal.

Supported P\&E personnel in installing a sealer at the South Parking Lot Valve Box around the penetration for the transfer line from Building 7966. This was being installed to try to prevent inleakage of water to the valve box.

Supported I\&C personnel in testing the discharge over pressurization shutdown for positive displacement pumps 4P1 and 4P2 used for LLLW concentrate transfers. 


\section{$\underline{\text { August }}$}

Replaced a leaking steam header isolation valve at Building 2099 (Monitoring and Control Station servicing Building 2026). Also replaced the bearings on ventilation fan EF-1.

Completed quarterly dike inspections at all LLLW System Facilities.

Repaired steam leaks at Building 2537 (LLLW Evaporator Service Tanks). Steam was used to jet waste from the tanks to the evaporators for treatment and to transfer contents of the sumps to the tanks for future treatment.

Completed closure of the Old Hydrofracture Valve Box. The valve box had been opened to install blanks in the transfer line from the Old Hydrofracture Facility after the recent completion of transfers from this facility.

Replaced the HEPA filters at Building 7966 (MCS servicing Bldgs. 7920 and 7930) after the filters were found plugging. The plugging was due to carry-over of entrained water from the air sparging of the tank. The entrained liquids exceeded the capacity of the demister to remove the liquids prior to reaching the filters, which resulted in saturating the filters and depositing LLLW in the HEPA filter housings. The air sparger was placed in standby and personnel decontaminated the housings.

\section{September}

Began marking stops on all valves from a specific supplier installed throughout the LLLW System. This provided positive valve position indication for operators and provided an easier method for lockout of the valves.

Completed disassembly of the old 4P1 pump that was removed from the Melton Valley Storage Tanks (Building 7830) earlier this year and placed the parts in B-25 boxes for transfer to Solid Waste Operations personnel.

\section{October}

Replaced a leaking steam valve at Building 2099 (Monitoring and Control Station for Building 2026). This steam valve provided isolation of the sump transfer jet at the facility.

Supported P\&E personnel with the tie-in of the new line from Building 7856 to the existing intervalley transfer line at the 7830 Valve Box.

Assisted I\&C personnel with calibration and checkout of instrumentation at the LLLW Evaporator Facility (Building 2531) and Evaporator Service Tanks (Building 2537). 


\section{November}

Repaired the automatic control function for the foundation drain sump at Building 2537 (Evaporator Service Tanks) after a broken wire was found in the control circuitry.

\section{December}

Provided assistance to $I \& C$ personnel calibrating the pressure transmitters for the discharge pressure from the transfer pumps at Building 7830 (Melton Valley Storage Tanks).

\subsection{Gaseous Waste System}

\section{$\underline{\text { February }}$}

Replaced the 4500 cell ventilation system duct's sump pump (located near Building 4501). This pump transfers condensation and inleakage from the duct to the Process Waste System for future treatment.

Changed out the demisters at Building 3092 (Off-gas Scrubber Facility) due to their plugging. The demisters were used to remove entrained liquids from the off-gas stream prior to reaching the HEPA filters.

April

Completed the quarterly load test of the 3039 Stack Area backup diesel generator (Building 3125).

Completed the scheduled DOP testing of the HEPA filters at Building 3092 (Off-Gas Scrubber Facility).

May

Repaired a failed solenoid valve on the cooling water supply system to the Isotope Area Cell Ventilation System's steam turbine-driven blower in the 3039 Stack Area that supplied backup cell ventilation to the Isotope Circle Area of the main ORNL Complex in Bethel Valley.

Completed the scheduled DOP testing of the HEPA filters at Bldgs. 7830 (Melton Valley Storage Tanks), 7860 (New Hydrofracture Facility), 7863 (General Storage for Building 7860), and 7877 (LLLW Solidification Facility). All filters were successfully tested. 
June

Supported I\&C personnel with the monthly test of the off-gas system pressure relief valve at Building 3092 (Off-gas Scrubber Facility).

August

Completed scheduled load test of the Building 3125 Diesel Generator. This generator provided backup power to the 3039 Stack Ventilation System.

An inspection of the 3039 Stack was performed. This inspection is performed approximately every year as a good management practice to assure the structural integrity of the stack.

Replaced the diaphragm on the Central off-gas recycle valve at Building 3092 (Off-Gas Scrubber Facility).

Replaced the North bank of HEPA filters at the Off-gas Scrubber Facility (Building 3092). The new filters were then successfully DOP tested by personnel from Quality Engineering and Inspection. These filters were used to remove particulates from off-gas in Bethel Valley prior to its discharge through the 3039 Stack.

Repaired a problem with the differential pressure instrumentation for the South bank of HEPA filters at Building 3092. A piece of equipment was relocated that was interfering with the sensor.

September

Supported I\&C personnel performing scheduled calibrations in the 3039 Stack Area.

\section{October}

Changed out the demister media in the Building 3092 (Off-Gas Scrubber Facility) demister due to plugging. The demister was used to remove entrained liquids from the off-gas stream prior to the HEPA filters to prevent plugging of the filters. 


\subsection{OTHER ACTIVITIES}

\subsection{Training}

$\underline{\text { January }}$

Several LGWOS personnel completed training on LGWOS safety documentation.

One LGWOS personnel completed a Nuclear Regulatory Commission Awareness seminar.

Several LGWOS personnel completed the annual required reading for 1998 RCRA Refresher training.

One LGWOS system administrator continued to self train on the OIS console and it operation. Also continued a self-paced course on DEC VAX/VMS System Administration.

\section{February}

Three LGWOS personnel completed the Radiation Worker II two-year refresher training.

All LGWOS shift foremen, chemical operators, and facility managers completed the pre-job briefing training.

\section{$\underline{\text { March }}$}

One LGWOS and one I\&C personnel completed a one-week training course for programming the programmable logic controllers being installed in the 7877 area.

\section{April}

One LGWOS technical staff member completed Conduct of Operations training.

May

Two LGWOS personnel Radiation Worker II refresher training.

One LGWOS personnel completed General Employee Training.

Two LGWOS personnel completed the 8-hour HAZWOPER annual refresher training. 
June

One LGWO personnel completed two training courses associated with Liquid Waste Certification activities.

One LGWOS technical staff member completed PUE training for the 611 procedures series. Three LGWOS personnel completed a video training on "The Power of Electricity."

$\underline{\text { July }}$

Two LGWOS personnel completed training on the new Documentation Records Management System.

August

Ten LGWOS personnel completed the General Employee Training two-year refresher course.

One LGWOS personnel completed Radiation Worker II refresher training.

One LGWOS staff member completed the annual respirator fit testing.

Nine LGWOS personnel completed On-the-Job training checklists for Building 7856.

One LGWOS personnel completed Lockout/Tagout Training.

Developed, documented, acquired approvals of new lesson plan related to Personal Protection Equipment/Fall Protection/Ladder Safety for inspections being conducted at Building 7856. Four LGWOS personnel then received fall protection training.

\section{September}

Two LGWOS personnel completed a 1 day "Chemistry for Non-Chemists" course.

One LGWOS personnel completed General Employee Training.

One LGWOS personnel completed a two-week UNIX operating system off-site training course on UNIX Utilities and Commands, and UNIX System Administration. This training is to assist in trouble-shooting continuing problems with the Tate Distributed Control System being installed as part of the MVST-CI Line Item Project.

Three LGWOS personnel completed drum closure compliance training. 
One LGWOS personnel completed Confined Space Entrant/Attendant training.

October

One LGWOS personnel completed Nuclear Criticality for Supervisors 2-year refresher training.

November

One LGWOS personnel completed the annual 8-hour HAZWOPER refresher training.

December

One LGWOS personnel completed a three day RCRA training course.

\subsection{Audits/Reviews/Tours}

$\underline{\text { January }}$

Participated in the annual criticality assessment of LGWOS activities. No problems or concerns were identified.

\section{February}

Met with personnel from the TDEC to review the PWTC. A detailed description of the PWTC was given and data was provided showing isotopic removal at various locations through the system.

$\underline{\text { March }}$

Conducted a Bechtel Jacobs representative on a tour of all LGWOS nonnuclear facilities (approximately 57 numbered facilities). Bechtel Jacobs was touring all LGWOS facilities prior to their assumption of responsibility for these facilities on April 1, 1998. The representative was very complementary of the condition of LGWOS facilities. In addition, a meeting was held with Bechtel Jacobs management personnel to review the results of the walk-throughs and evaluations of LGWOS' nuclear facilities. No problems or concerns were identified for any of the nuclear facilities and personnel were very complementary of the information provided by LGWOS personnel and the status of the facilities. 
$\underline{\text { April }}$

Conducted a tour for the ORNL and DOE-ORO Readiness Self-Assessment teams of the Melton Valley Storage Tanks Annex (Building 7856).

$\underline{\text { June }}$

Provided a tour for OSHA personnel of the Process Waste Treatment Complex - Building 3608 to assist in their evaluation of which facilities to cover under their program.

Participated in the week-long ESH\&Q audit of WMOD activities by ORNL personnel. No significant concerns or problems were identified.

$\underline{\text { July }}$

Completed due-diligence walkthroughs of the following LGWOS facilities by BJC personnel: Bldgs. 7582, 7802E, 7813, 7830, 7853, 7860, 7863A, 7863B, 7863C, 7872, $7881,7882,7913,7919,7922,7935,7952$, and 7961. No significant problems were identified.

Escorted personnel from BJC to the Melton Valley area so they could begin their evaluation for building a road for the planned TRU Processing Facility.

August

Conducted personnel on an OSHA inspection of the Process Waste Treatment Complex Building 3608.

Provided due diligence check sheets on 54 LGWOS facilities to BJC personnel. Walkdowns of these facilities were then conducted by LGWOS personnel.

\section{September}

Completed an OSHA inspection of Bldgs. 7860, 7922, 7935, and 7952 with no findings identified.

Participated in the corporate ES \& H Audit. No major findings or concerns were identified associated with the Liquid Waste Certification Program. 


\section{Qctober}

Gave a tour to personnel from the Pollution Prevention section. The purpose of the tour was to show these people the facilities and to help them understand the types of wastes generated at each location.

\section{November}

Participated in the LMER Line Item and DOE-ORO Readiness Assessment team reviews of the Melton Valley Storage Tanks Capacity Increase Project (see Section 2.1.2 for additional discussion).

\subsection{Environmental Restoration Support Activities}

January

Transferred one tanker load of process waste from the 7500 Canal to the Process Waste Collection and Transfer System for future treatment at the request of Environmental Restoration personnel.

Replaced the filter at the Seep D treatment system. This system was operated by LGWOS personnel at the request of Environmental Restoration personnel.

Repaired the Seep C Treatment System's sump pump. This system was operated by LGWOS personnel at the request of Environmental Restoration personnel.

Transferred approximately 4,000 gallons from inactive tank W-6 to W-9 at the request of Environmental Restoration personnel.

\section{February}

Transferred approximately 75,056 gallons from inactive tank W-8 to the LLLW Collection and Transfer System at the request of Environmental Restoration personnel.

Transferred approximately 19,000 gallons from inactive tank W-6 to W-9 at the request of Environmental Restoration personnel.

Replaced the Seep D zeolite column with a column loaded with fresh zeolite. The Seep D treatment system was operated by LGWOS personnel at the request of Environmental Restoration personnel.

Assisted Environmental Restoration personnel with the video inspection and smearing the interiors of inactive tanks W-19 and W-20. 
Set up a pumping system and transferred approximately 18,000 gallons from inactive tank W-6 to W-8. LGWOS personnel then set up the pumping system to resume transfer of the W-8 tank's contents to the LLLW Collection and Transfer System for future treatment. This was done at the request of Environmental Restoration personnel.

Collected approximately 5,000 gallons of process waste in the process waste tanker from operations at the Hill cut tanks in Solid Waste Storage Area 6 and transferred the tanker's contents to the Process Waste Collection and Transfer System for future treatment. This was done at the request of Environmental Restoration personnel.

\section{$\underline{\text { March }}$}

Transferred two 5,000 gallon tanker loads of water to the emergency pond at Old Hydrofracture Site at the request of Environmental Restoration personnel.

Transferred approximately 14,053 gallons from inactive tank W-8 to the LLLW Collection and Transfer System at the request of Environmental Restoration personnel.

Collected a sludge sample from tank T-3 at the Old Hydrofracture Site and submitted the sample to laboratory personnel for analysis. This was done at the request of Environmental Restoration personnel.

Assisted in the installation of a new pump suction line into inactive tank W-6 to allow additional transfers to inactive tank W-8. This was done at the request of Environmental Restoration personnel.

Transferred 11,600 gallons from inactive tank W-6 to W-8. Also provided support to P\&E personnel during the changeout of the HEPA filter for tank W-6. These activities were done at the request of Environmental Restoration personnel.

\section{April}

Supported changeout of the HEPA filters for inactive LLLW Tank W-1A at the request of Environmental Restoration personnel.

Supported personnel performing a wet tap of the transfer line from the tanks at the Old Hydrofracture Facility.

Supplied Chem Tech personnel with two 55-gallon containers of wastewater from the Seep D Treatment System to support a resin study that was underway. 
Transferred the contents of the west valve pit in the South Tank Farm to the LLLW Collection and Transfer System for future treatment at the request of Environmental Restoration personnel.

Transferred LLLW from inactive tank W-9 to inactive tank W-8 at the request of Environmental Restoration personnel.

$\underline{\text { May }}$

Transferred process wastewater from the 190 Ponds (Bldgs. 3539, 3540) to the Process Waste Collection and Transfer System for future treatment. This was done at the request of Environmental Restoration personnel.

Completed transferring LLLW from inactive tank W-9 to W-8 at the request of Environmental Restoration personnel, with a total of 90,000 gallons being transferred during the past 2 and $1 / 2$ weeks.

Collected a supernate sample from inactive tank W-8 at the request of Environmental Restoration personnel.

Assisted personnel with the tie-in of the new transfer line from the Old Hydrofracture Facility to the Old Hydrofracture Valve Box. This tie-in will support Environmental Restoration personnel in transferring the contents of the tanks at the facility to the Melton Valley Storage Tanks (Building 7830) in the near future.

Completed the monthly sampling of the Seep C and Seep D treatment systems operated by LGWOS personnel at the request of Environmental Restoration personnel.

$\underline{\text { June }}$

Supported Environmental Restoration personnel with a test of the transfer piping from the Old Hydrofracture Facility to the Melton Valley Storage Tanks (Building 7830) in preparation for transfers of material in the near future.

Changed out a spent zeolite column at the Seep D Treatment System. This system was operated by LGWOS personnel at the request of Environmental Restoration personnel.

Began transfer of LLLW from inactive tank W-8 to the LLLW Collection and Transfer System for future treatment at the request of Environmental Restoration personnel.

Transferred the contents of the west pit in the South Tank Farm to inactive tank W-5 at the request of Environmental Restoration personnel. 
$\underline{\text { July }}$

Transferred approximately 95,842 gallons from inactive tank W-8 to the LLLW Collection and Transfer System for future treatment at the request of Environmental Restoration personnel.

Transferred the contents of a pit in the South Tank Farm to the LLLW System at the request of Environmental Restoration personnel.

Transferred waste from Old Hydrofracture tank T-9 to T-4 at the request of Environmental Restoration personnel.

Completed the following transfers from the Old Hydrofracture Facility to the Melton Valley Storage Tanks (Building 7830):

- On July $13^{\text {th }}$ transferred approximately 13,480 gallons of waste from T-4 to W-28 (also received 350 gallons of flush water).

- On July $15^{\text {th }}$ transferred approximately 10,140 gallons of waste and flush water from T-2 to W-28.

- Completed the final transfer on July $18^{\text {th }}-19^{\text {th }}$ of approximately 12,300 gallons from T-1 to tanks W-27 (received 3,900) and W-28 (received 8,400).

Transferred three tankers of process waste from the 7500 canal pool at the request of Environmental Restoration personnel. This was the start of activities to empty the pool at the facility.

\section{$\underline{\text { August }}$}

Assisted in a wet-tap of the LLLW Line at the Old Hydrofracture Valve Box and blew out the contents of the pipeline from Old Hydrofracture. This was done as part of the demobilization activities presently underway at this Environmental Restoration facility.

Transferred approximately 32,000 gallons of LLLW from inactive tank W-5 to inactive tank W-7 at the request of Environmental Restoration personnel.

Transferred approximately 18,000 gallons of process waste from the Building 7500 pool in preparation for the clean out and grouting of the pool. This was done at the request of Environmental Restoration personnel.

Assisted personnel at the Old Hydrofracture Facility at the request of Environmental Restoration personnel. The following activities were completed in support of demobilization:

- Transferred liquid out of pipelines.

- Decontaminated the pump module room. 
Transferred 1,000 gallons from the Hill Cut Tanks to the process waste tanker. The tanker's contents were then transferred to the Process Waste Collection and Transfer System for future treatment. This was done at the request of Environmental Restoration personnel.

Transferred three tankers (approximately 5,000 gallons each) of water to the Old Hydrofracture Emergency Pond at the request of Environmental Restoration personnel to reduce background from the pond.

Transferred one 55 gallon container of wastewater from the Seep D treatment system to Chem Tech Division personnel for testing. This system was operated by LGWOS personnel at the request of Environmental Restoration personnel.

Transferred the water off of the top of the grout in the 7500 Canal at the request of Environmental Restoration personnel.

\section{September}

Transferred process wastewater from Building 3513 Service Impoundment to provide space to support the upcoming 190 Ponds (Bldgs. 3539, 3540) Remediation Activities.

Transferred three loads of water to the Emergency Pond at the Old Hydrofracture Facility to reduce background from the pond at the request of Environmental Restoration personnel.

Rinsed tanks W-13, -14 , and -15 at the request of Environmental Restoration personnel.

Transferred LLLW from inactive tank W-3 to inactive tank W-5 at the request of Environmental Restoration personnel.

Transferred LLLW from inactive tank W-5 to inactive tank W-9 and from inactive tank W-8 to $\mathrm{W}-5$ at the request of Environmental Restoration personnel.

Provided support to construction personnel performing a pipe cut for the Building 3110 filters.

\section{October}

Completed the following activities for Environmental Restoration personnel:

- Transferred approximately 100,000 gallons from inactive LLLW tank W-9 to inactive LLLW tank W-8.

- Transferred LLLW from inactive tank W-5 to W-9.

Transferred 500 gallons from the Tower Shielding Facility using the Process Waste tanker to the Process Waste Collection and Transfer System for future treatment. 
Received one tanker load of process wastewater from Solid Waste Storage Area 5 and transferred the tanker's contents to the Process Waste Collection and Transfer System for future treatment. This was done at the request of Environmental Restoration personnel.

Provided assistance to personnel in the Chemical Technology in the development of a paper on the SEEP C project.

Completed monthly sampling of the Seep C and D treatment systems at the request of Environmental Restoration personnel.

November

Assisted Environmental Restoration personnel in cleanup of a water problem at Building 3002.

Transferred water to the emergency pond at the Old Hydrofracture facility at the request of Environmental Restoration personnel.

Supported sampling activities at tank W-5 and transferred water between tanks in the South Tank Farm at the request of Environmental Restoration personnel.

Removed and reloaded one zeolite column for the Seep D Treatment System with fresh zeolite in preparation for it's return to service next week. Also removed a second zeolite column from service at the Seep D treatment system and placed the spare column in service after the column was found to be leaking into the containment dike area. This system was operated by LGWOS personnel at the request of Environmental Restoration personnel.

Collected the monthly samples at the Seep C and D Treatment System.

December

Transferred approximately 44,000 gallons of LLLW from inactive tank W-8 to the LLLW Collection and Transfer System for future treatment at the request of Environmental Restoration personnel.

Flushed the over ground transfer piping system at tank W-5 and cleaned up the area at the request of Environmental Restoration personnel. 


\subsection{Federal Facility Agreement for the LLLW System Activities}

\section{February}

Collected a sample from LLLW Tank WC-9 and submitted for analysis at the request of FFA personnel.

Collected a sample from the bottom of LLLW Tank W-16 and submitted for analysis at the request of FFA personnel.

Sampled tank 2026A and delivered samples to laboratory personnel for analysis at the request of FFA personnel.

Collected a sample from inactive tank TH-4 at the request of FFA personnel and delivered the sample to Laboratory personnel for characterization analysis.

Collected a sludge sample from inactive LLLW tank WC-4 at the request of FFA personnel and delivered the sample to Laboratory personnel for characterization analysis.

Transferred approximately 120 gallons of concentrate from the nitric acid recovery evaporator at the Process Waste Treatment Complex - Building 3544 to tank WC-2 in an effort to dissolve the sludge layer in the tank. This was done at the request of FFA personnel.

\section{$\underline{\text { March }}$}

Collected a sample from tank WC-2 at the request of FFA personnel and delivered the sample to Laboratory personnel for characterization analysis.

Collected a sludge sample from LLLW Tank WC-9 at the request of the FFA program and delivered the sample to laboratory personnel for analysis.

Collected a sample from a High Integrity Container containing water from the recently completed WC-14 sludge removal activities and submitted the sample to laboratory personnel for analysis.

\section{April}

Completed video inspection of the interiors of tanks WC-2, WC-9, and W-16 at the request of FFA personnel.

Added approximately 200 gallons of acidic waste by tanker truck from the L-11 Evaporator at the Process Waste Treatment Complex - Building 3544 to LLLW Tank WC-2 at the 
request of FFA personnel to assist in the dissolution of sludges in the tank. A second transfer of approximately 330 gallons of LLLW Concentrate from the evaporator system at the Process Waste Treatment Complex - Building 3544 to inactive LLLW Tank WC-2 was made after the video inspection showed some sludge remained in the tank after transferring the dissolved sludge to the LLLW Collection and Transfer System for future treatment. At the end of the month a second video inspection was performed to evaluate the effectiveness of the second dissolution.

Collected a sludge sample from LLLW Tank W-16 and submitted to laboratory personnel for analysis. The sample was collected at the request of FFA personnel.

$\underline{\text { May }}$

Transferred the third acid dissolution of the remaining sludge heel in tank WC-2 to the LLLW Collection and Transfer System for future treatment. Personnel then performed two video inspections of the interior of the tank to determine the effectiveness of the dissolution work and to assist in future work planning. This was done at the request of FFA personnel.

Transferred the liquid contents from inactive LLLW Tank WC-9 to the LLLW Tanker, which was then transferred to the LLLW Collection and Transfer System for future treatment. This was done at the request of FFA personnel in preparation for personnel to collect a sample of the sludge layer in the tank.

Supported P\&E personnel performing a wet-tap into the drain line from Building 3110 . This was done at the request of FFA personnel to assist in characterization activities associated with this facility.

$\underline{\text { June }}$

Performed a video inspection of inactive LLLW Tank WC-2 at the request of FFA personnel. Also provided support to $P \& E$ personnel beginning excavations for the isolation of inactive LLLW Tank WC-2.

Sampled the sludge layer in inactive tank WC-9 and delivered to laboratory personnel for analysis (done at the request of FFA personnel).

Transferred one load of acidic LLLW from the evaporator operation at the Process Waste Treatment Complex - Building 3544 to LLLW Tank W-16. This was done at the request of FFA program personnel to assist with the dissolution of any sludges in the tank. 
$\underline{\text { July }}$

Completed video inspection of tanks W-16, W-17, and W-18 at the request of FFA personnel.

\section{August}

LGWOS personnel completed the following activities in support of the FFA Program:

- Transferred one load of nitric acid waste from the evaporator operations at Building 3544 to tank W-16 to assist in the dissolution of any remaining sludges in the tank.

- Added 10 gallons of degreaser to W-16 in support of the final clean out of the tank.

Transferred 180 gallons of nitric acid waste to LLLW Tank WC-9 to assist in the dissolving of any sludge remaining in the tank. This was done at the request of FFA personnel.

\section{September}

Sampled sludge from inactive LLLW Tanks W-17 and W-18 at the request of FFA personnel.

Provided support to isolation of inactive LLLW Tank WC-2 being performed by the FFA program.

Reinstalled the plug for the 2026 Tank Vault that had been removed to allow sampling/inspection work by FFA program personnel.

Sampled the side wall of the interior of inactive tank W-16 and submitted the sample for analysis.

Sampled inactive tank WC-3 for sludge and liquid samples and submitted the samples for analysis. Also supported video camera inspection of the interior of the tank.

\subsection{Miscellaneous}

January

Sampled the sludge in tank W-23 at the Evaporator Service Tanks (Building 2537) and delivered the sample to laboratory personnel for analysis. This data will be used to support upcoming work to remove the sludge from this tank.

Performed several transfers between tanks at the LLLW Evaporator Facility (Bldgs. 2531, 2537) and the Melton Valley Storage Tanks (Building 7830) in support of the AEA Sludge Mobilization Project and the Out-of-Tank Evaporation Project. Transferred 2,100 gallons of LLLW concentrate from tank C-1 to W-21 on Jan 8. Transferred approximately 16,500 
gallons from W-23 to W-22 on Jan. 14 in preparation for the beginning of sludge mobilization activities in tank W-22. At Building 7830 on Jan. 16 transferred 3,380 gallons from $\mathrm{W}-24$ to $\mathrm{W}-26 ; 3,660$ gallons from $\mathrm{W}-24$ to $\mathrm{W}-28 ; 5,210$ gallons from $\mathrm{W}-25$ to $\mathrm{W}-28$; 1,120 gallons from $\mathrm{W}-25$ to $\mathrm{W}-31$; and 1,000 gallons from W-25 to W-27. On Jan. 21 transferred 1,200 gallons from tank W-30 to W-21 and 9,830 gallons from W-30 to W-23. Personnel then performed the first mobilized sludge transfer from W-22, with 28,440 gallons being transferred from $\mathrm{W}-22$ to $\mathrm{W}-24$. On Jan. 23 personnel transferred 830 gallons from W-25 to W-21; 557 gallons from W-25 to C-1; 1,600 gallons from W-21 to C-1; 6,390 gallons from $\mathrm{W}-25$ to $\mathrm{C}-1$; and 2,480 gallons from W-26 to C-1.

Transferred the contents of the South Parking Lot Valve Box to the process waste tanker, which was then transferred to the Process Waste Collection and Transfer System for future treatment.

Transferred the HFIR tank's drywell to the Process Waste System in an effort to determine if the source of inleakage to the tank would be stopped if the groundwater layer was lowered.

Received one load of caustic at the Process Waste Treatment Complex - Building 3608. Caustic was used at this facility to adjust the $\mathrm{pH}$ of the wastewater to within discharge limits prior to discharge to White Oak Creek. The storage tank at this facility was also the main holding facility for caustic used at other LGWOS facilities.

Transferred one load of caustic from Building 3608 to Building 7961 (Melton Valley Process Waste Collection Tanks Facility). Caustic was used at this facility to maintain the process wastewater received at a basic $\mathrm{pH}$ prior to transfer to Bethel Valley for future treatment.

Transferred one load of sodium hydroxide (caustic) to the storage tank at Building 2099. Caustic was used to adjust the $\mathrm{pH}$ of the waste received at Building 2099 to a basic range prior to its transfer to the LLLW Evaporator Facility.

Transferred one load of sulfuric acid from the Process Waste Treatment Complex - Building 3608 storage tank to the Process Waste Treatment Complex - Building 3544. Sulfuric acid was used to adjust the $\mathrm{pH}$ of the wastewater at Building 3544 prior to transfer to Building 3608 for further treatment.

Obtained approval from the Site Development and Design Review Committee for the installation of a parking lot on the north side of the Building 2101 changehouse. This was being done by the LGWOS PMT as a safety issue raised by several LGWOS employees due to the lack of adequate parking at the facility creating a hazard for pedestrians. 


\section{February}

Sampled tank W-22 at the Evaporator Service Tanks (Building 2537) and delivered the sample to laboratory personnel for analysis. This data was used to determine the effectiveness of acid addition during the AEA Sludge Mobilization campaign to dissolve the remaining sludge layer in the tank.

Sampled tank W-24 at Building 7830 (Melton Valley Storage Tanks) in preparation for the upcoming Out-of-Tank Evaporation Campaign 98-3.

Transferred the contents of the 4PRS sump at Building 7830 (Melton Valley Storage Tanks) to the LLLW Tanker. The tanker's contents were then transferred to the LLLW Collection and Transfer System for future treatment.

Transferred T-13 at Building 7860 (New Hydrofracture Facility) to the LLLW Evaporator Service Tanks to flush the intervalley transfer line after completing the AEA Sludge mobilization transfers. This was done at the request of Engineering personnel to reduce background rates at the new valve box being installed by the Melton Valley Storage Tanks Capacity Increase Line Item Project at Building 7830.

Performed several intertank transfers on Feb. 20 at the Melton Valley Storage Tanks (Building 7830) in preparation for the upcoming Out-of-Tank Evaporation Campaign 98-3. Transferred 4,460 gallons from W-29 to W-25; 16,370 gallons from W-30 to W-26; and 25,135 gallons from W-24 to W-29.

Transferred approximately 140 gallons of concentrate by LLLW Tanker from the nitric acid recovery evaporator at the Process Waste Treatment Complex - Building 3544 to the LLLW Evaporator Facility for future treatment.

\section{$\underline{\text { March }}$}

Received one tanker load (approximately 3,000 gallons) of sodium hydroxide (caustic) at the Process Waste Treatment Complex - Building 3608. The caustic was used to adjust the $\mathrm{pH}$ of the wastewater to assist in the water-softening operations conducted at the facility.

Received approximately 3,000 gallons of nitric acid at the Process Waste Treatment Complex - Building 3544 . This acid was used to regenerate the ion-exchange columns at the facility.

Cleaned out the rapid mix tank (F-1003) and the spare clarifier (F-1007) at the Process Waste Treatment Complex - Building 3608. 
Completed clean-out the rapid mix tank (F-1003) and the spare clarifier (F-1007) at the Process Waste Treatment Complex - Building 3608.

April

Transferred 3 tanker loads (approximately 5,000 gallons each) from the Hill Cut facility to the Process Waste Collection and Transfer System at the request of Solid Waste Operations personnel.

Received one load (approx. 3,500 gallons) of sulfuric acid at Building 3608. Sulfuric acid was used to adjust the $\mathrm{pH}$ of the wastewater prior to discharge to White Oak Creek.

Transferred two tanker loads of sulfuric acid from the storage tank at the Process Waste Treatment Complex - Building 3608 to Building 3544. The acid was used to adjust the $\mathrm{pH}$ of the wastewater treated at Building 3544 prior to its transfer to Building 3608 for further treatment.

Walked down a planned parking lot for Building 2101 with a P\&E field engineer.

\section{$\underline{\text { May }}$}

In preparation for future transfers to the Melton Valley Storage Tanks Facility (Building 7830) personnel on May 6 transferred approximately 16,426 gallons from W-28 to W-22 at the LLLW Evaporator Service Tanks (Building 2537) and on May 8 transferred approximately 16,970 gallons from W-28 to W-22.

Collected samples ( 3 liquid samples each) from tanks W-24 and W-25 at Building 7830 (Melton Valley Storage Tanks (Building 7830) and measured the sludge depths at the request of the TRU Program.

Collected one LLLW Bottled Waste package from Building 4500S and transferred the contents to the LLLW Collection and Transfer System for future treatment.

Completed the quarterly acid cleaning of the air stripper at the Process Waste Treatment Complex - Building 3608. This cleaning was to remove algae and other buildup from the air stripper's packing.

Received one trailer load of sodium hydroxide (caustic) at the Process Waste Treatment Complex - Building 3608. Caustic was used to adjust the $\mathrm{pH}$ of the wastewater to aid in the water softening operations conducted at this facility. 
Transferred two tanker loads of sulfuric acid from the storage tank at Building 3608 to Building 3544 . The acid was used to adjust the $\mathrm{pH}$ of the wastewater at Building 3544 prior to transfer to Building 3608 for further treatment.

$\underline{\text { June }}$

Completed several transfers involving the concentrate storage tanks at Building 7830 (Melton Valley Storage Tanks) and the Evaporator Service Tanks (Building 2537). Transferred approx. 6,000 gallons from W-30 to W-23; approx. 15,000 gallons from W-27 to W-23; and approx. 14,000 gallons from W-27 to W-26. These transfers were performed in preparation for several transfer activities to Building 7830 in the upcoming weeks.

Transferred the contents of the Melton Valley Storage Tanks (Building 7830) sumps to the LLLW Tanker. It's contents were then transferred to the LLLW Collection and Transfer System for future treatment.

Collected samples from tanks W-24 and W-25 at Building 7830 and submitted them to laboratory personnel for analysis.

Supported P\&E personnel performing tie-inn of the off-gas filter pit at Building 2531 (LLLW Evaporator Facility) to the existing off-gas ductwork. This was being constructed by the BV FFA Line Item Project.

Transferred one load of sulfuric acid within the Process Waste Treatment Complex from Building 3608 's bulk storage tank to Building 3544 . The acid was used to adjust the $\mathrm{pH}$ of the effluent from Building 3544's treatment process prior to discharge to Building 3608 for further treatment.

Received one load of sodium hydroxide (caustic) at Bldgs. 3544 and 3608. Caustic was used for water softening and $\mathrm{pH}$ adjustment of the effluent prior to discharge to White Oak Creek at these facilities.

$\underline{\text { July }}$

Supported P\&E personnel with tie-in of the new aboveground filter banks facility at the LLLW Evaporator Facility to the 3039 Stack Ventilation System.

\section{August}

Transferred the contents of the sumps at the Melton Valley Storage Tanks (Building 7830) to the LLLW Tanker. The tanker was then transported to the Central Waste Collection Header, where its contents were transferred to the LLLW Collection and Transfer System for future treatment. 
Transported the 3074 Dumpster Tank to the Central Waste Collection Header twice during the month, where its contents were transferred to the LLLW Collection and Transfer System for future treatment.

Due to a valve malfunction, approximately 350 gallons of liquid low level waste were inadvertently transferred to the process waste system during a transfer from Building 3019 . This caused extremely high alpha readings throughout the process waste collection and treatment systems. LGWOS personnel made numerous process changes throughout the month in an effort to minimize alpha concentrations in the Building 3608 effluent, necessitating notification of the DOE and State. No permit limits were exceeded due to this event.

\section{September}

Completed the following activities at the Process Waste Treatment Complex - Building 3608:

- Received two tanker loads of sodium hydroxide (caustic). Caustic was used to adjust the $\mathrm{pH}$ of the wastewater to assist in the water softening operations at Building 3608 and to adjust the $\mathrm{pH}$ to meet discharge parameters prior to discharge to White Oak Creek.

- Removed algae growth from the top service of the F-1007 Clarifier. This clarifier was used for water softening operations at the facility.

- $\quad$ Received one tanker load of sulfuric acid at Building 3608. Sulfuric acid was used throughout LGWOS facilities for $\mathrm{pH}$ adjustment of wastewater.

Provided support to construction personnel performing the steam pipe work on the west end of the main ORNL complex.

\section{October}

Provided support to personnel performing a video inspection of the off-gas line to the new Cell Vent and Off-gas Filter Facility (Building 2568) for the LLLW Evaporator Facility. The inspection was to identify the cause of a blockage in the inlet piping to the filters.

Received one load of sodium hydroxide (caustic) at the Process Waste Treatment Complex Bldgs. 3544 and 3608. Caustic was used to adjust the $\mathrm{pH}$ of the wastewater at the facilities to assist in the water-softening process and to adjust $\mathrm{pH}$ prior to discharge to White Oak Creek.

\section{November}

Assisted MVST-CIP Line Item project personnel with removal of demineralized water from the tanks at Building 7856 (Melton Valley Storage Tanks Annex). This water was used to assist in the calibration of the tanks' level instrumentation during functional testing, but was being removed in preparation for startup activities. 
Completed emptying demineralized water from the tanks at Building 7856 that had been used for calibration of the tank level instrumentation.

Performed initial valve lineups for all systems at Building 7856 after LGWOS assumed facility manager responsibilities.

Completed pressure test of the tie-in work at the new 7830 Valve Box for the Melton Valley Storage Tanks - Capacity Increase Project.

Collected a sample from the Central Off-Gas Scrubber Solution Tank (F-801) at Building 3092 and submitted it for analysis to support on-going waste acceptance activities for the LLLW System.

December

Transferred the contents of the 3074 Dumpster Tank (approximately 200 gallons) to the LLLW Collection and Transfer System for future treatment.

Transported three tanker loads of LLLW from HFIR (Building 7900) to the Central Waste Collection Header, where the tanker's contents were transferred to the LLLW Collection and Transfer System for future treatment.

Disconnected tubing and removed the WC-2 instrument cabinet. This was part of the cleanup activities associated with the removal of inactive tank WC-2 from service by the FFA Program.

Obtained sludge level readings in tanks C-1 and C-2 at Building 2531 (LLLW Evaporator Facility) in preparation for the installation of the AEA Technologies sludge mobilization system later in the month.

Completed extensive cleanup work in the equipment room at Building 7860 (New Hydrofracture Facility).

Completed the decontamination of several wells in Solid Waste Storage Area 5 at the request of Solid Waste Operations personnel.

Added an extension to the stack at Building 7966 (Monitoring and Control Station for the Radiochemical Engineering Development Complex) to move the stack exhaust above the roof being installed in the filter area of the facility.

Completed installation of packing glands and conduit sealing at the South Parking Lot valve box to eliminate water in leakage to the valve box. 
Completed the installation of the new access man way to filter L-3B at the Process Waste Treatment Complex - Building 3544 and returned the filter to service.

Transferred one tanker load of sulfuric acid from the storage tanks at the Process Waste Treatment Complex - Building 3608 to Building 3544 . The acid was used to adjust the $\mathrm{pH}$ of the wastewater prior to discharge to Building 3608 for further treatment.

Received one tanker load of sodium hydroxide (caustic) which was split between the Process Waste Treatment Complex - Bldgs. 3544 and 3608 . Caustic was used to adjust the $\mathrm{pH}$ of the wastewater to assist in the treatment process and to achieve the proper $\mathrm{pH}$ prior to discharge to White Oak Creek.

Transported a tanker load of LLLW concentrate from the Process Waste Treatment Complex - Building 3544 evaporator operations to the Central Waste Collection Header, where its contents were transferred to the Evaporator Service Tanks for storage. 


\subsection{APPENDIX}

\section{$5.1 \quad$ TABLES}

1. Process Waste Treatment Complex - Building 3544 operations.

2. Process Waste Treatment Complex - Building 3608 operations.

3. LLLW operations.

4. Rainfall at ORNL.

\subsection{FIGURES}

1. Diagram of the Process Waste Collection and Transfer System. (ORNL-DWG. 963390R1)

2. Flow diagram of Building 3544. (ORNL-DWG. 96-3391R1)

3. Process waste treated at ORNL. (ORNL-DWG. 97-5448R2)

4. Sludge generation at Building 3544. (ORNL-DWG. 97-5449R2)

5. Dilute LLLW from Building 3544. (ORNL-DWG. 97-5450R2)

6. LLLW concentrate from Building 3544. (ORNL-DWG. 97-5451R2)

7. Rainfall at ORNL. (ORNL-DWG. 97-5452R2)

8. Flow diagram of Building 3608. (ORNL-DWG. 96-3397R1)

9. Nonradiological waste treated at ORNL. (ORNL-DWG. 97-5453R2)

10. Sludge generation at the Building 3608. (ORNL-DWG. 97-5454R2)

11. Diagram of the LLLW Collection and Transfer System. (ORNL-DWG. 96-3400R1)

12. Used storage space versus time. (ORNL-DWG. 97-5455R2)

13. LLLW generation at ORNL. (ORNL-DWG. 97-5456R2)

14. Building 2026 LLLW generation. (ORNL-DWG. 97-5457R2)

15. Building 3019 LLLW generation. (ORNL-DWG. 97-5458R2)

16. Building 3025 LLLW generation. (ORNL-DWG. 97-5459R2)

17. Building 3026-C LLLW generation. (ORNL-DWG. 97-5460R2)

18. Building 3026-D LLLW generation. (ORNL-DWG. 97-5461R2)

19. 3039 Stack Area LLLW generation. (ORNL-DWG. 97-5463R2)

20. Building 3074 LLLW generation. (ORNL-DWG. 97-5464R2)

21. Building 3517 LLLW generation. (ORNL-DWG. 97-5466R2)

22. Building 3544 LLLW concentrate generation. (ORNL-DWG. 97-5468R2)

23. 4500 Complex LLLW generation. (ORNL-DWG. 97-5470R2)

24. Isotopes Area LLLW generation. (ORNL-DWG. 97-5471R2)

25. WC-5 Pump Pit (tank WC-9) LLLW generation. (ORNL-DWG. 97-5474R2)

26. HFIR (Building 7900) LLLW generation. (ORNL-DWG. 97-5475R2)

27. Building 7920 LLLW generation. (ORNL-DWG. 97-5476R2)

28. Abandoned tank W-1A LLLW generation. (ORNL-DWG. 97-5477R2)

29. Diagram of the Gaseous Waste System. (ORNL-DWG. 96-3528) 


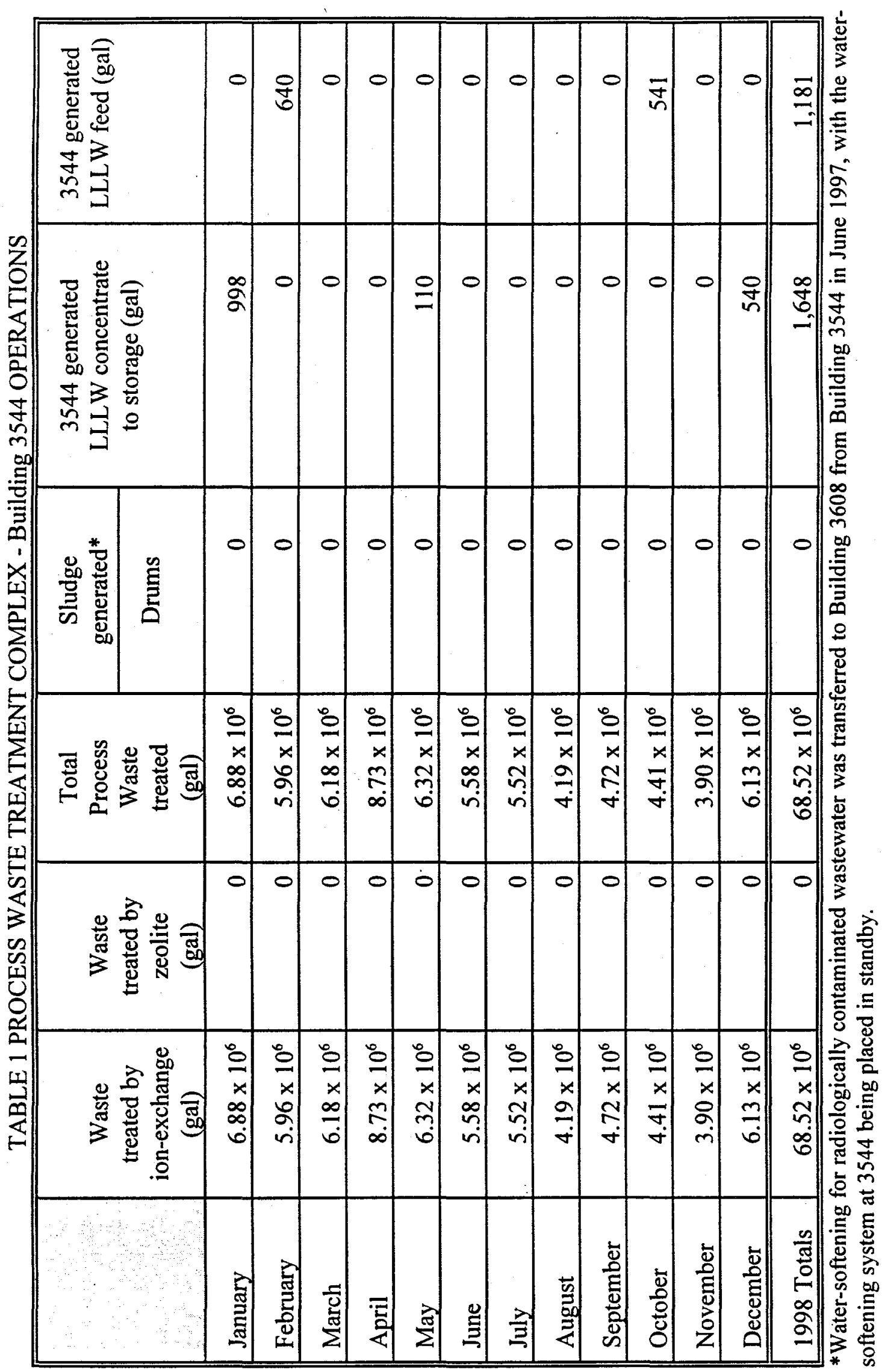


TABLE 2 PROCESS WASTE TREATMENT COMPLEX - Building 3608 OPERATIONS

\begin{tabular}{|l|r|r|r|r|r||}
\hline \multirow{2}{*}{} & \multirow{2}{*}{$\begin{array}{c}\text { Metals Wastewater } \\
\text { treated } \\
\text { (gal) }\end{array}$} & $\begin{array}{c}\text { Nonmetals } \\
\text { Wastewater } \\
\text { treated } \\
\text { (gal) }\end{array}$ & $\begin{array}{c}\text { Total Wastewater } \\
\text { treated } \\
\text { (gal) }\end{array}$ & \multicolumn{2}{|c||}{ Sludge generated } \\
\cline { 5 - 7 } & $3.40 \times 10^{5}$ & $1.52 \times 10^{7}$ & $1.55 \times 10^{7}$ & 5 & $\mathrm{Ft}^{3}$ \\
\hline January & $3.40 \times 10^{5}$ & $1.39 \times 10^{7}$ & $1.42 \times 10^{7}$ & 5 & 480 \\
\hline February & $4.80 \times 10^{5}$ & $1.52 \times 10^{7}$ & $1.57 \times 10^{7}$ & 6 & 480 \\
\hline March & $3.00 \times 10^{5}$ & $1.82 \times 10^{7}$ & $1.85 \times 10^{7}$ & 5 & 576 \\
\hline April & $3.00 \times 10^{5}$ & $1.54 \times 10^{7}$ & $1.57 \times 10^{7}$ & 7 & 480 \\
\hline May & $5.20 \times 10^{5}$ & $1.48 \times 10^{7}$ & $1.53 \times 10^{7}$ & 4 & 384 \\
\hline June & $5.60 \times 10^{5}$ & $1.54 \times 10^{7}$ & $1.60 \times 10^{7}$ & 4 & 384 \\
\hline July & $91.00 \times 10^{5}$ & $0.60 \times 10^{7}$ & $1.51 \times 10^{7}$ & 5 & 480 \\
\hline August & $59.70 \times 10^{5}$ & $0.99 \times 10^{7}$ & $1.59 \times 10^{7}$ & 4 & 384 \\
\hline September & $6.56 \times 10^{5}$ & $1.43 \times 10^{7}$ & $1.50 \times 10^{7}$ & 4 & 384 \\
\hline October & $7.50 \times 10^{5}$ & $1.35 \times 10^{7}$ & $1.42 \times 10^{7}$ & 3 & 288 \\
\hline November & $8.02 \times 10^{5}$ & $1.58 \times 10^{7}$ & $1.66 \times 10^{7}$ & 5 & 480 \\
\hline December & $201.18 \times 10^{5}$ & $16.76 \times 10^{7}$ & $18.77 \times 10^{7}$ & 57 & 5,472 \\
\hline 1998 Totals & & & & 5 \\
\hline
\end{tabular}

Water-softening for radiologically contaminated wastewater was transferred to Building 3608 from Building 3544 in June 1997 . This resulted in the increased volume of sludge generated at Building 3608 . 
TABLE 3 LLLW OPERATIONS

\begin{tabular}{|c|c|c|c|c|}
\hline $\begin{array}{r}48 \\
8 \\
\end{array}$ & $\begin{array}{c}\text { LLLW treated by } \\
\text { Evaporator } \cdot A 2 \\
\text { (gal) }\end{array}$ & $\begin{array}{l}\text { LLLW treated by } \\
\text { Evaporator } 2 \mathrm{~A} 2 \\
(\mathrm{gal})\end{array}$ & $\begin{array}{c}\text { Concentrate transferred } \\
\text { from A2 } \\
\text { (gal) }\end{array}$ & $\begin{array}{c}\text { Concentrate transferred } \\
\text { from } 2 \mathrm{~A} 2 \\
\text { (gal) }\end{array}$ \\
\hline January & $1.09 \times 10^{4}$ & $1.45 \times 10^{4}$ & 0 & 2,771 \\
\hline February & $1.38 \times 10^{4}$ & $8.30 \times 10^{4}$ & 2,050 & 0 \\
\hline March & $0.30 \times 10^{4}$ & $2.28 \times 10^{4}$ & 0 & 0 \\
\hline April & $2.22 \times 10^{4}$ & $3.95 \times 10^{4}$ & 0 & 2,680 \\
\hline May & $0.21 \times 10^{4}$ & $2.62 \times 10^{4}$ & 1,460 & 1,087 \\
\hline June & $1.64 \times 10^{4}$ & $1.75 \times 10^{4}$ & 0 & 1,010 \\
\hline July & $4.32 \times 10^{4}$ & $6.19 \times 10^{4}$ & 0 & 0 \\
\hline August & $0.18 \times 10^{4}$ & $0.68 \times 10^{4}$ & 0 & 1,150 \\
\hline September & $1.67 \times 10^{4}$ & $1.47 \times 10^{4}$ & 1,400 & 0 \\
\hline October & $0.35 \times 10^{4}$ & 0 & 0 & 0 \\
\hline November & 0 & $0.92 \times 10^{4}$ & 0 & 0 \\
\hline December & $4.01 \times 10^{4}$ & $3.12 \times 10^{4}$ & 1,000 & 1,850 \\
\hline 1998 Totals & $17.37 \times 10^{4}$ & $32.73 \times 10^{4}$ & 5,910 & 10,548 \\
\hline
\end{tabular}


TABLE 4. RAINFALL AT ORNL

(Data collected at the ORNL Steam Plant, all results are in inches)

\begin{tabular}{|c|c|c|c|c|c|c|c|c|c|c|c|c|c|}
\hline Year & January & February & March & April & May & June & July & August & September & October & November & December & Total \\
\hline 1989 & 8.04 & 5.17 & 5.36 & 0.00 & 6.34 & 0.00 & 4.26 & 4.26 & 11.02 & 1.93 & 5.25 & 2.96 & 54.59 \\
\hline 1990 & 6.09 & 8.08 & 5.13 & 3.05 & 8.53 & 1.81 & 8.28 & 6.54 & 1.74 & 4.55 & 2.20 & 12.27 & 68.27 \\
\hline 1991 & 2.93 & 9.01 & 7.56 & 3.56 & 4.41 & 6.57 & 4.20 & 3.75 & 2.14 & 1.73 & 3.85 & 9.75 & 59.46 \\
\hline 1992 & 3.82 & 3.45 & 3.64 & 3.03 & 6.23 & 2.70 & 4.31 & 6.17 & 4.06 & 3.56 & 2.84 & 6.82 & 50.63 \\
\hline 1993 & 4.08 & 3.65 & 5.75 & 4.54 & 3.35 & 2.89 & 1.45 & 4.42 & 4.72 & 2.67 & 3.74 & 7.89 & 49.15 \\
\hline 1994 & 6.94 & 8.77 & 10.81 & 8.86 & 3.52 & 7.20 & 4.75 & 5.65 & 3.09 & 2.54 & 3.96 & 2.87 & 68.96 \\
\hline 1995 & 7.02 & 4.37 & 3.53 & 2.65 & 6.86 & 2.78 & 3.05 & 2.84 & 3.41 & 4.30 & 6.80 & 5.62 & 53.23 \\
\hline 1996 & 7.62 & 3.40 & 6.74 & 4.28 & 9.30 & 5.10 & 8.48 & 3.29 & 5.33 & 1.64 & 8.32 & 6.06 & 69.56 \\
\hline 1997 & 5.51 & 5.00 & 6.60 & 5.79 & 6.92 & 5.99 & 3.59 & 3.01 & 3.46 & 3.44 & 2.69 & 3.29 & 55.29 \\
\hline 1998 & 4.10 & 3.78 & 5.17 & 11.00 & 2.89 & 6.10 & 2.29 & 0.83 & 1.93 & 1.45 & 2.00 & 6.56 & 48.10 \\
\hline Average & 5.62 & 5.47 & 6.03 & 4.68 & 5.83 & 4.11 & 4.47 & 4.08 & 4.09 & 2.78 & 4.17 & 6.41 & 57.72 \\
\hline
\end{tabular}


ORAL PMOCESS WASTE SYSTEM

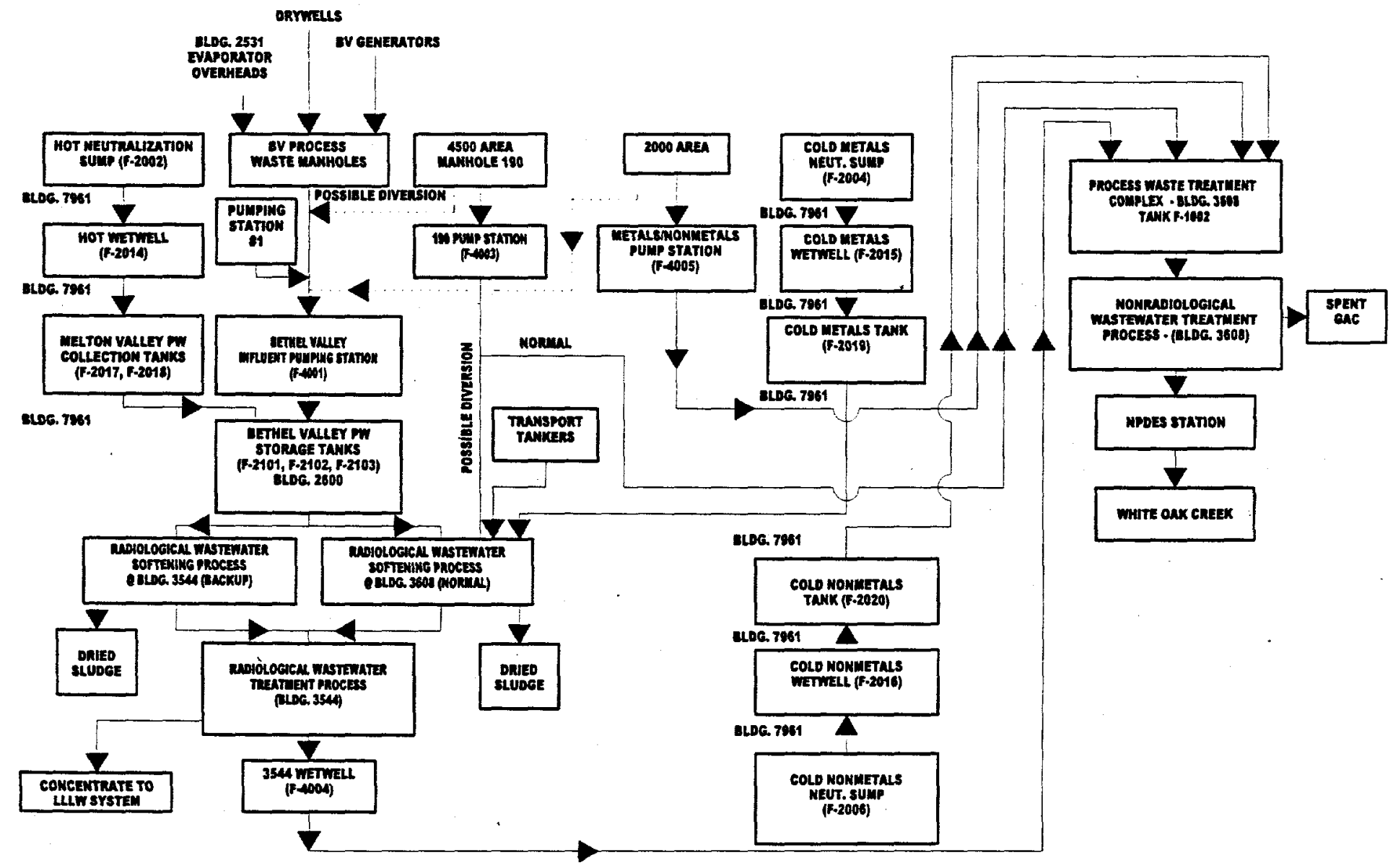

Figure 1. Diagram of the Process Waste Collection and Transfer System.

(ORNL-DWG. 96-3390R1) 


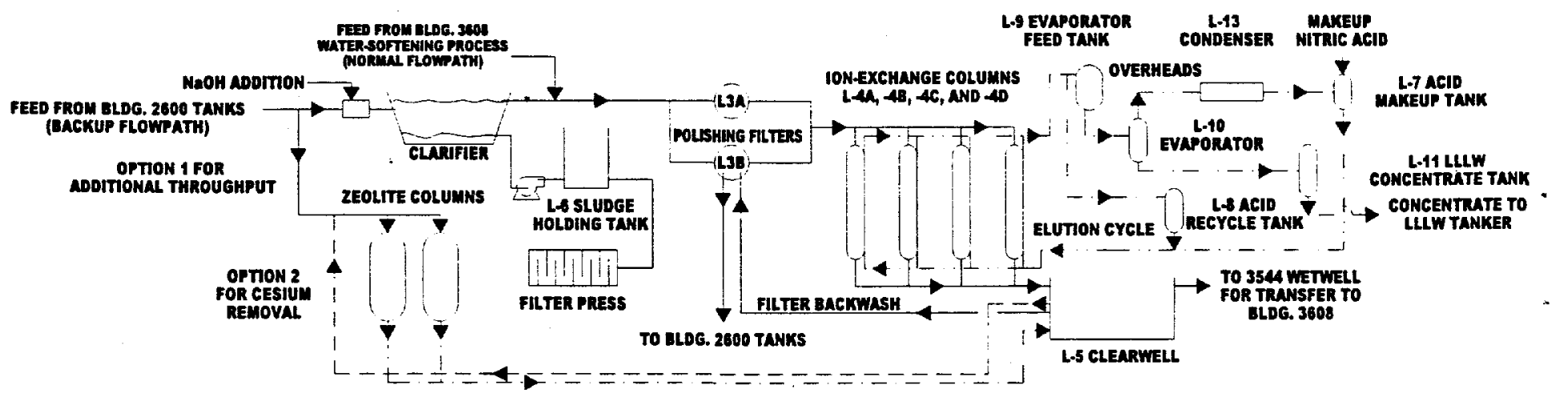

BLDG. 3544 FLOW DIAGRAM

Figure 2. Flow diagram of Building 3544. (ORNL-DWG. 96-3391R1) 


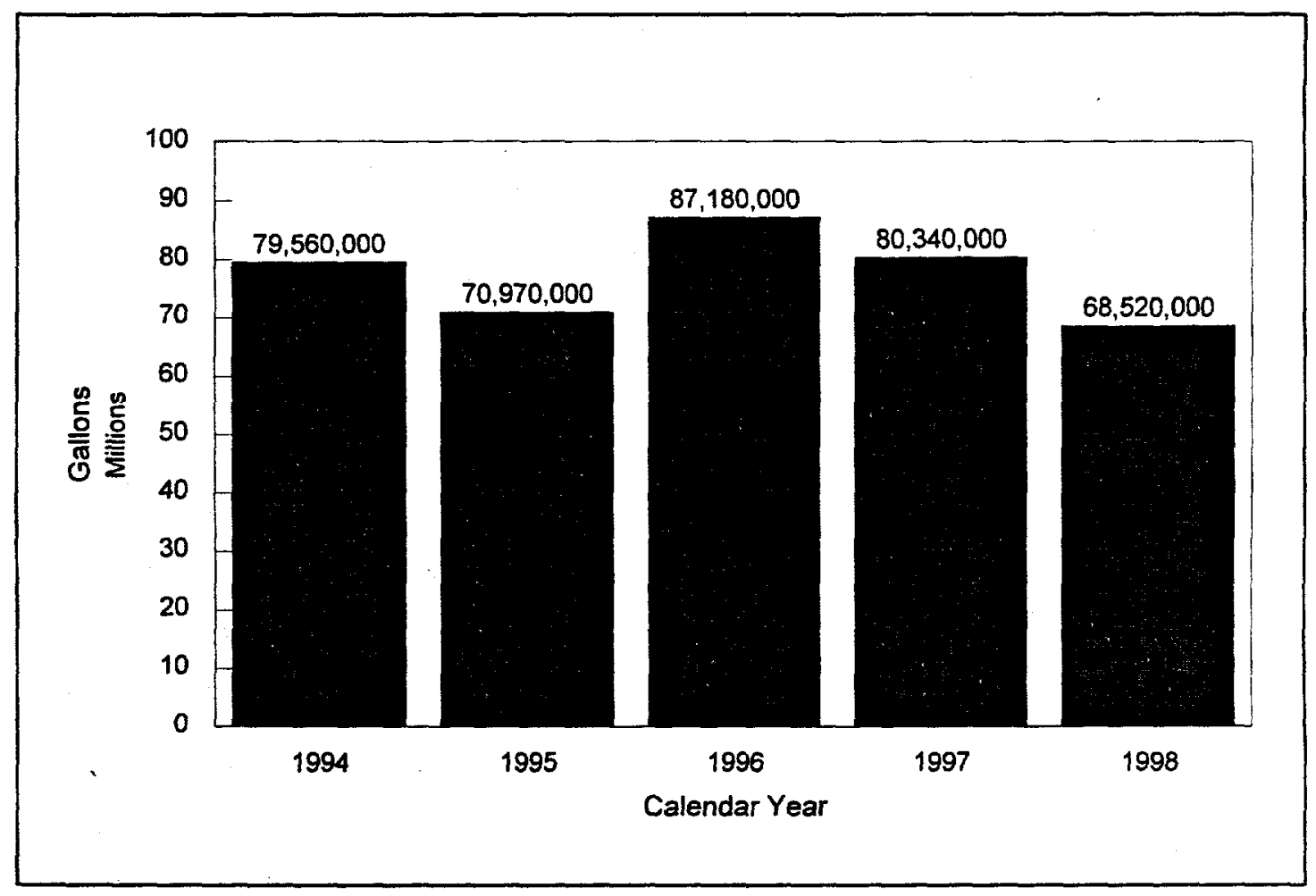

Figure 3. Process waste treated at ORNL. (ORNL-DWG. 97-5448R2) 


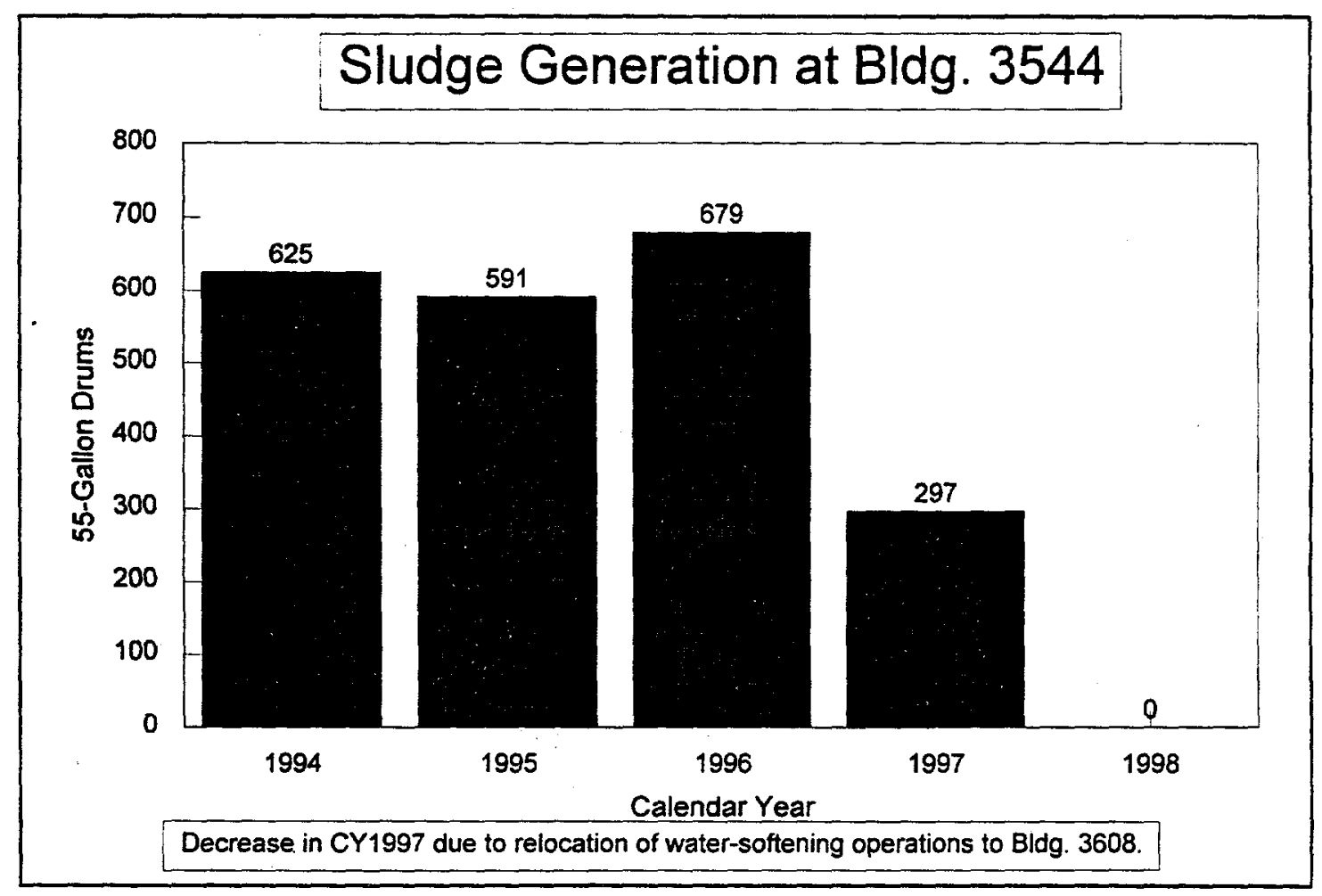

Figure 4. Sludge generation at Building 3544. (ORNL-DWG. 97-5449R2) 


\section{Dilute LLLW from Bldg. 3544}

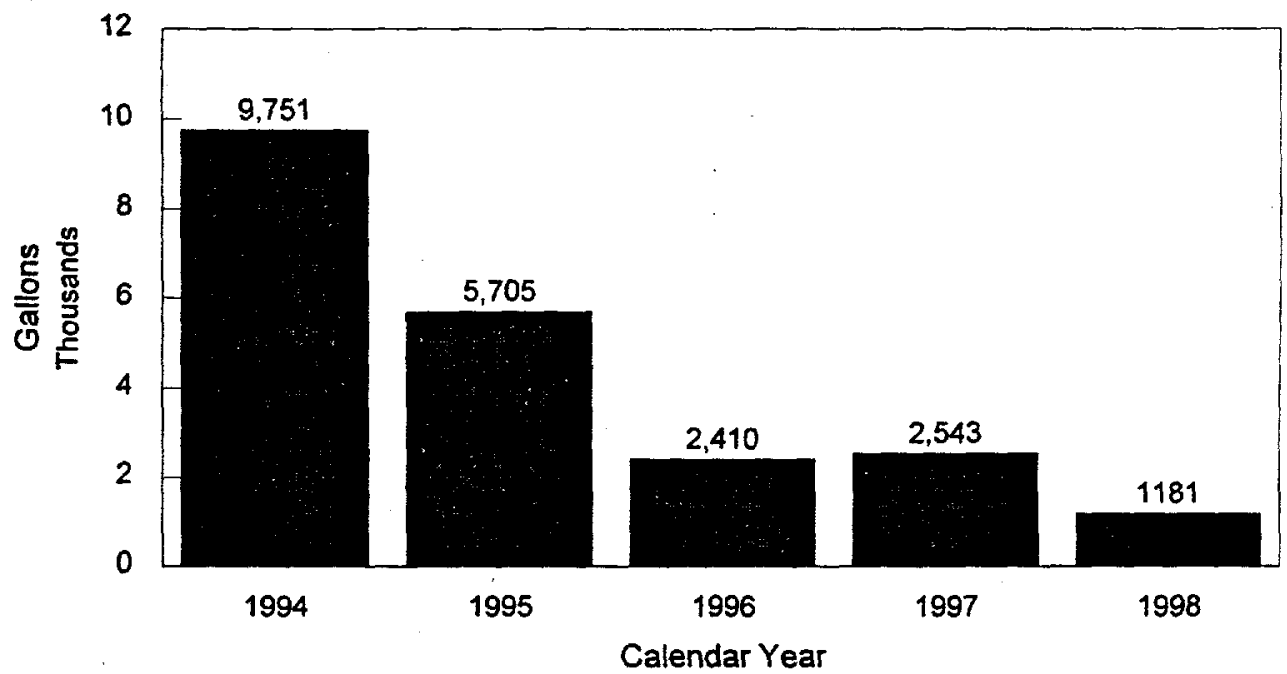

In late CY1997, discontinued use of hard-piped connection to LLLW System and began trucking operations.

Figure 5. Dilute LLLW from Building 3544. (ORNL-DWG. 97-5450R2) 


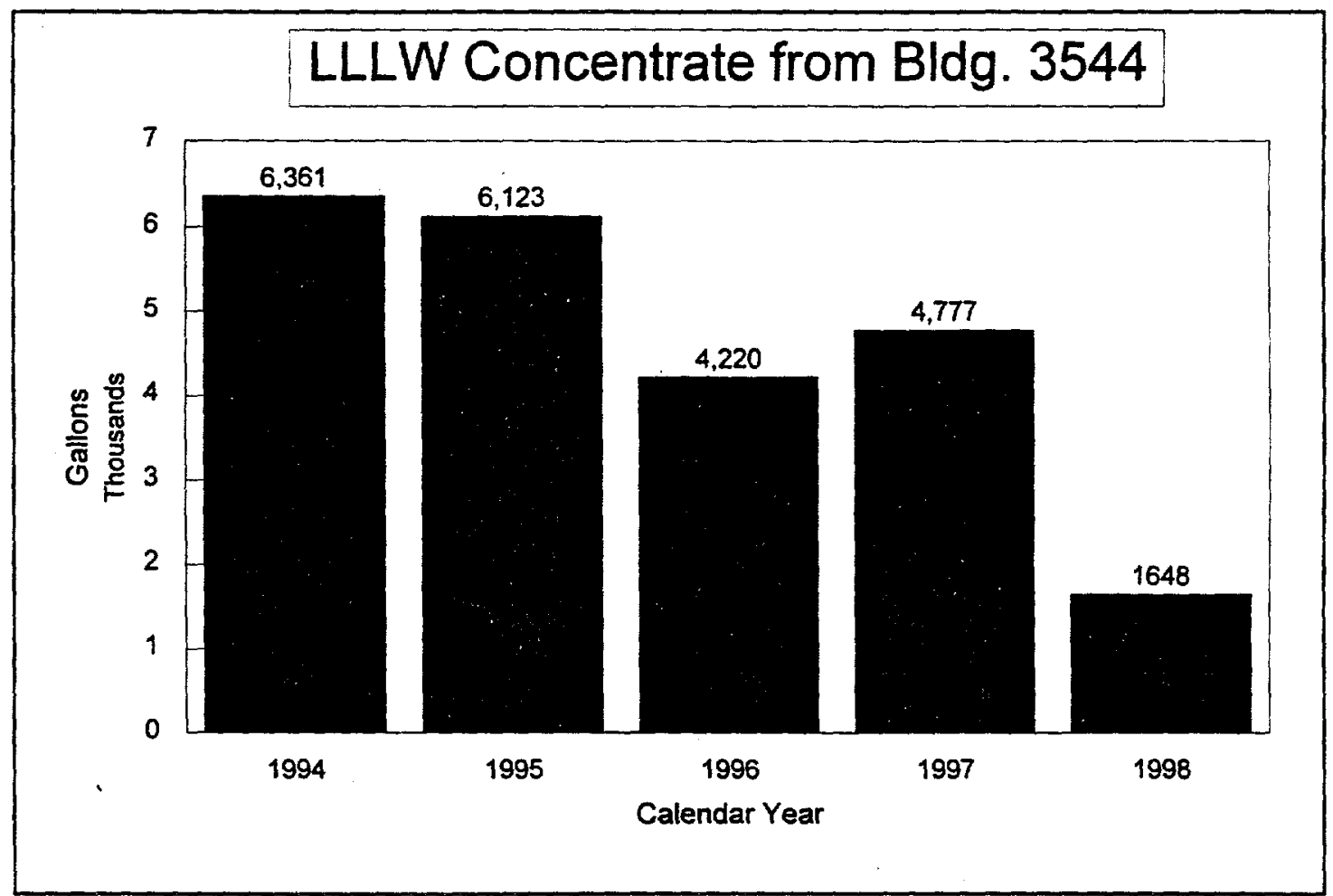

Figure 6. LLLW concentrate from Building 3544. (ORNL-DWG. 97-5451R2) 


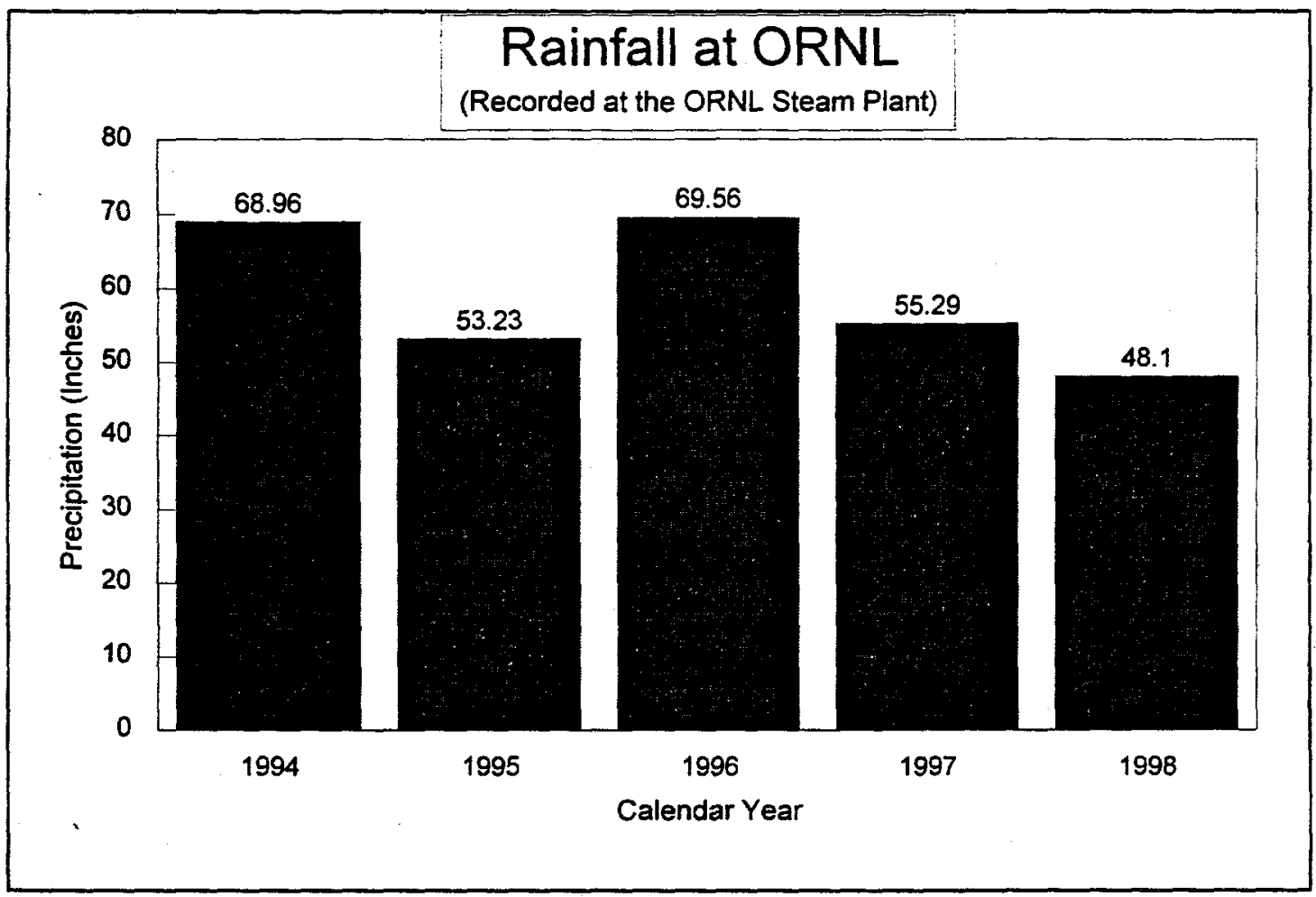

Figure 7. Rainfall at ORNL. (ORNL-DWG. 97-5452R2) 


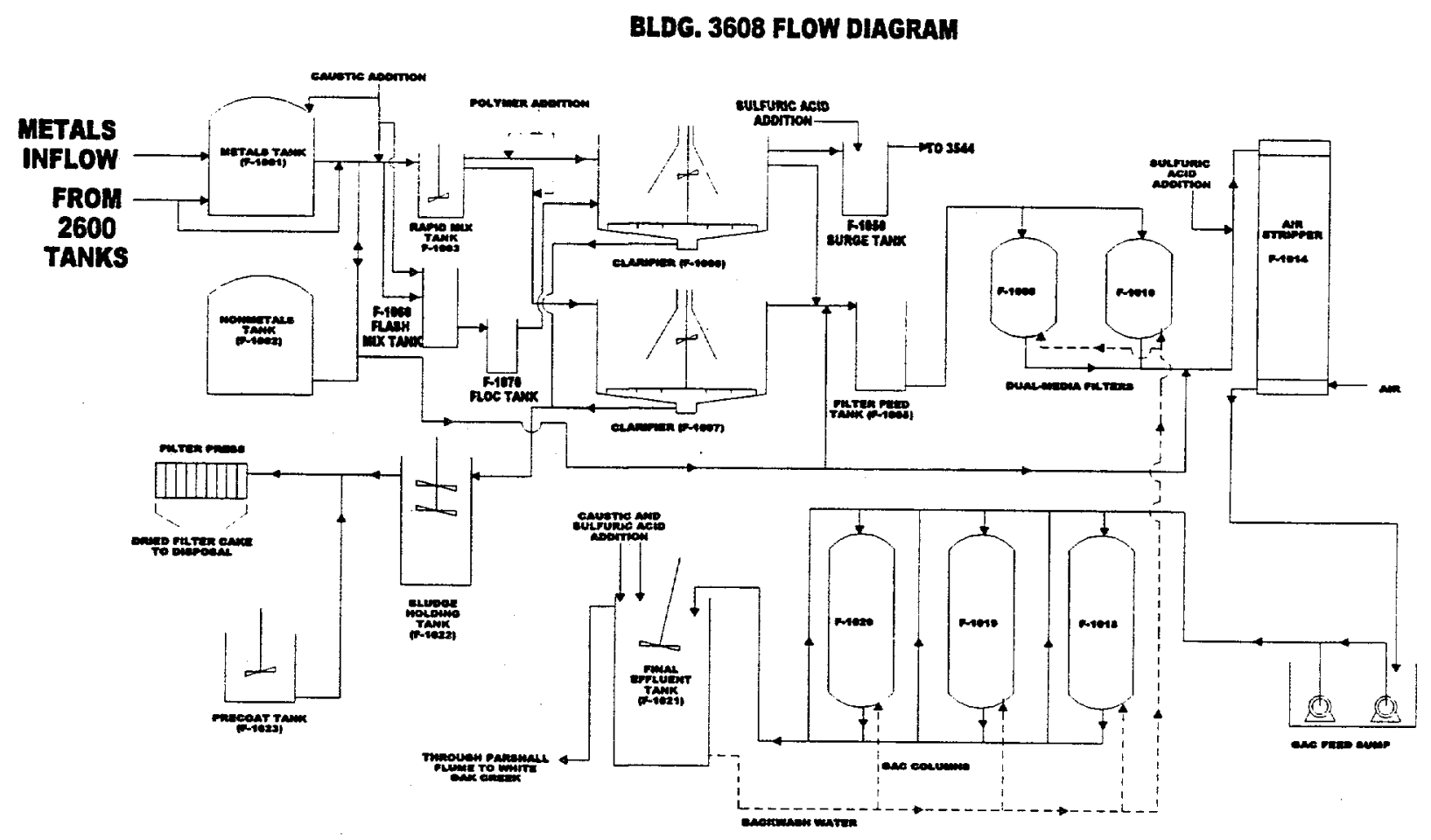

Figure 8. Flow Diagram of Building 3608. (ORNL-DWG. 96-3397R1) 


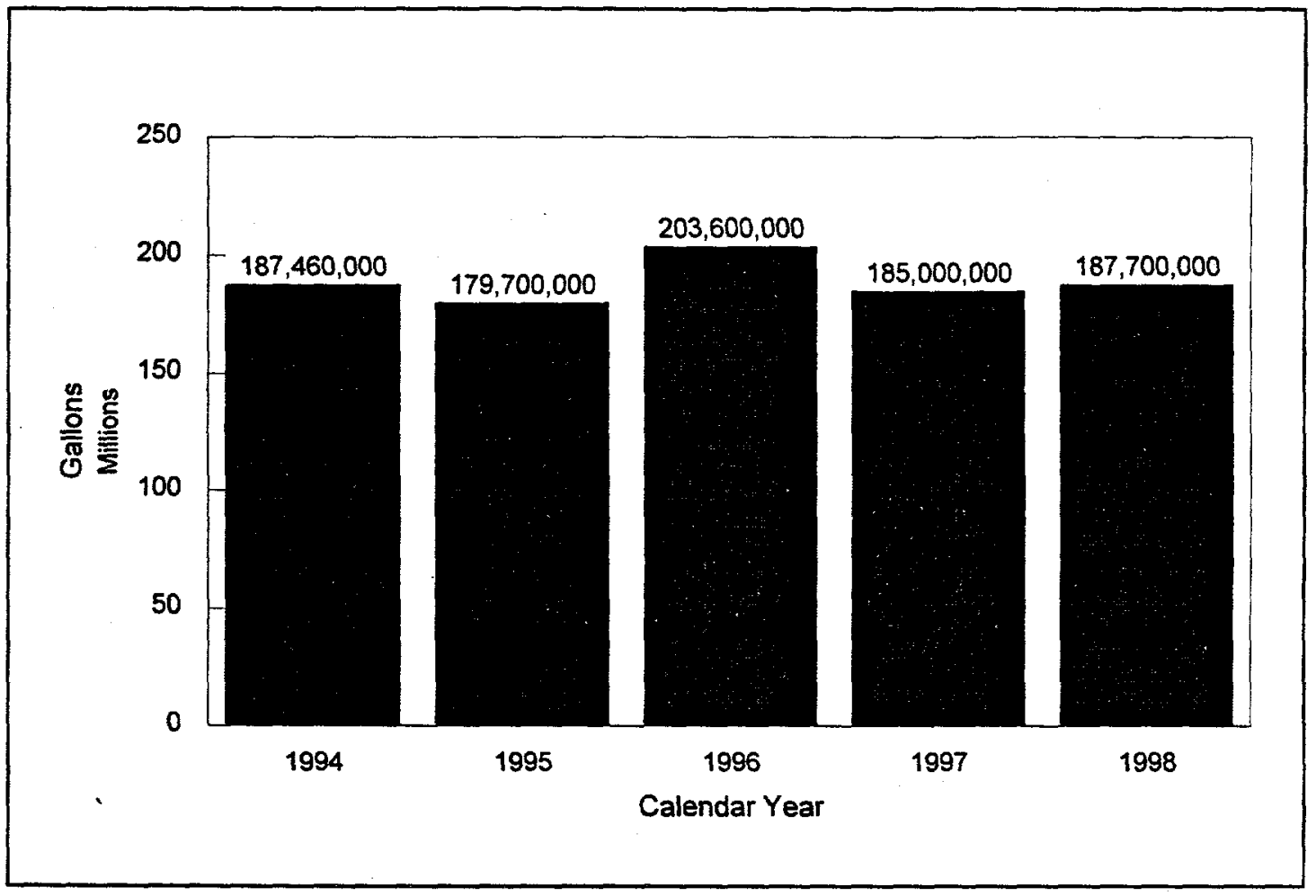

Figure 9. Nonradiological waste treated at ORNL. (ORNL-DWG. 97-5453R2)

$-107-$ 


\section{Sludge Generation at Bldg. 3608}

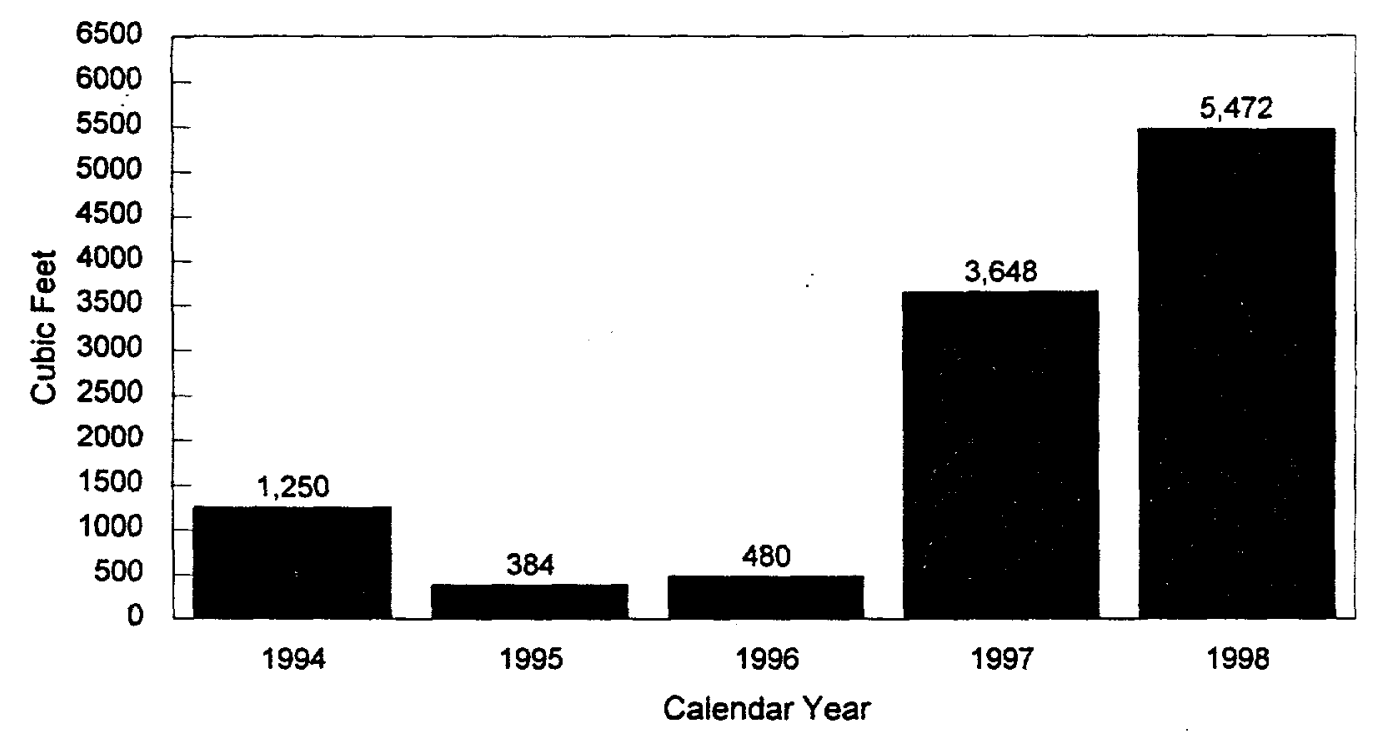

Increase in CY1997 due to relocation of water-softening operations from Bldg. 3544 .

Figure 10. Sludge generation at Building 3608. (ORNL-DWG. 97-5454R2) 


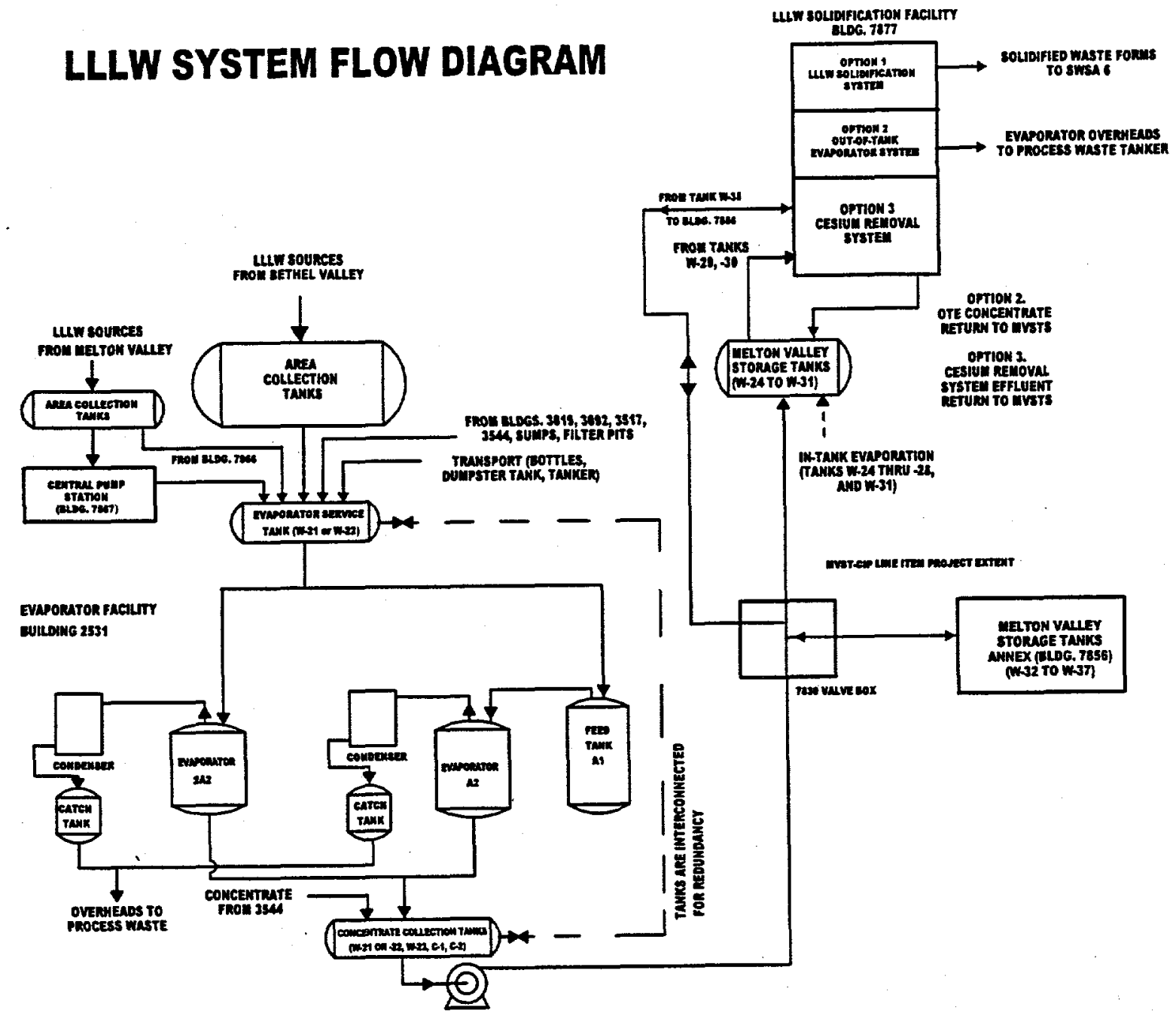

Figure 11. Diagram of the LLLW Collection and Transfer System.

(ORNL-DWG. 96-3400R1) 


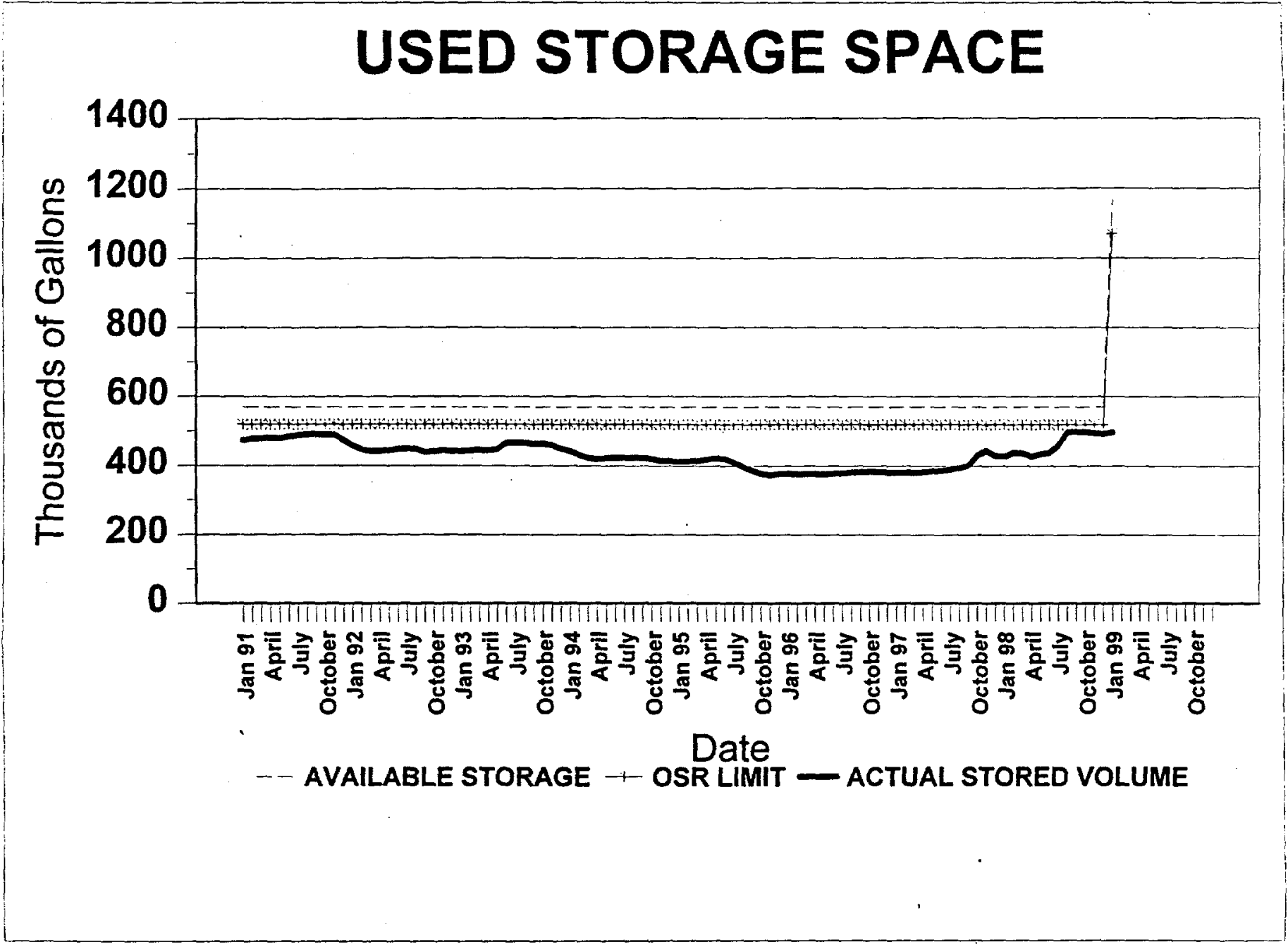

Figure 12. Used storage space versus time. (ORNL-DWG. 97-5455R2) 


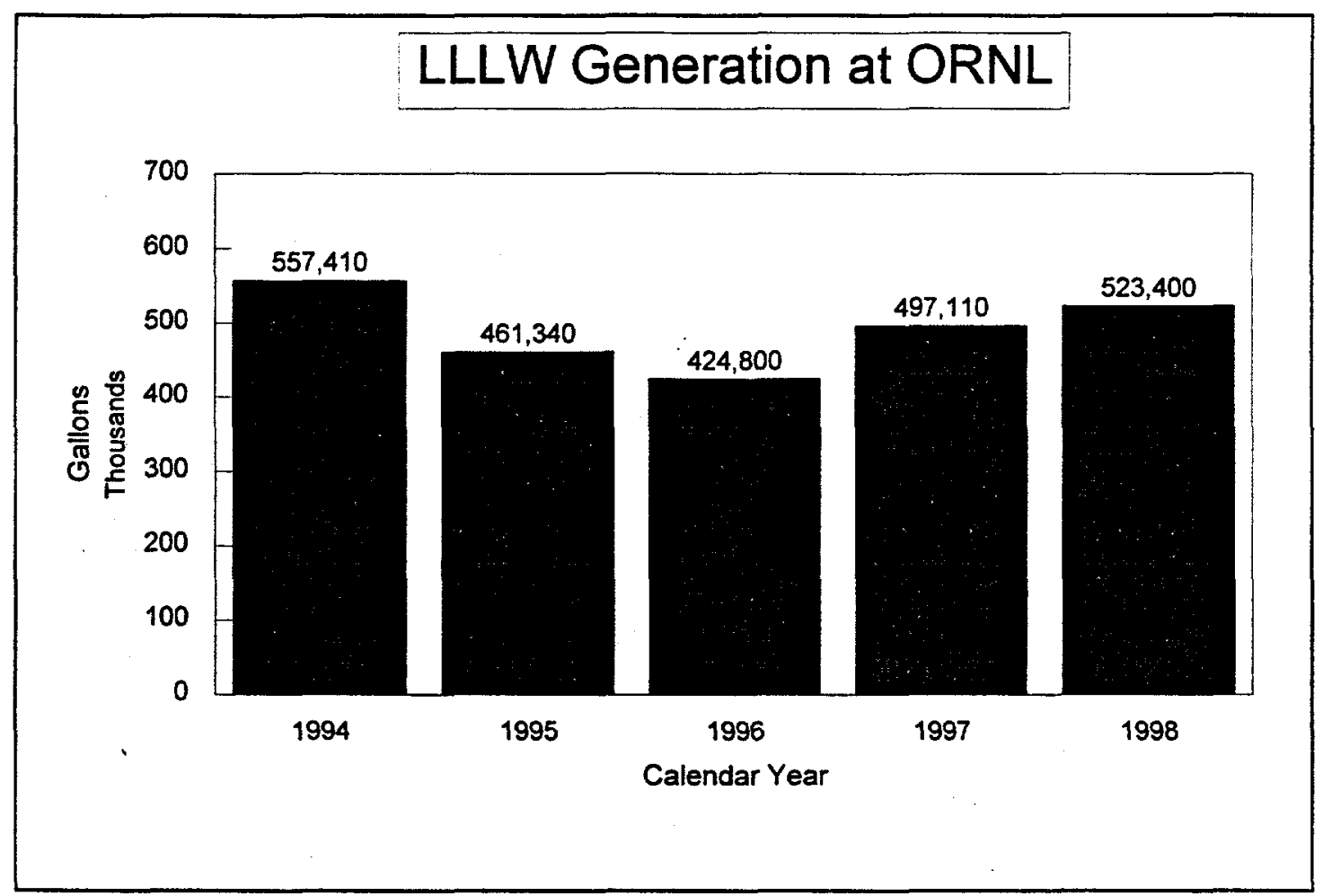

Figure 13. LLLW generation at ORNL. (ORNL-DWG. 97-5456R2) 


\section{Building 2026 LLLW Generation}

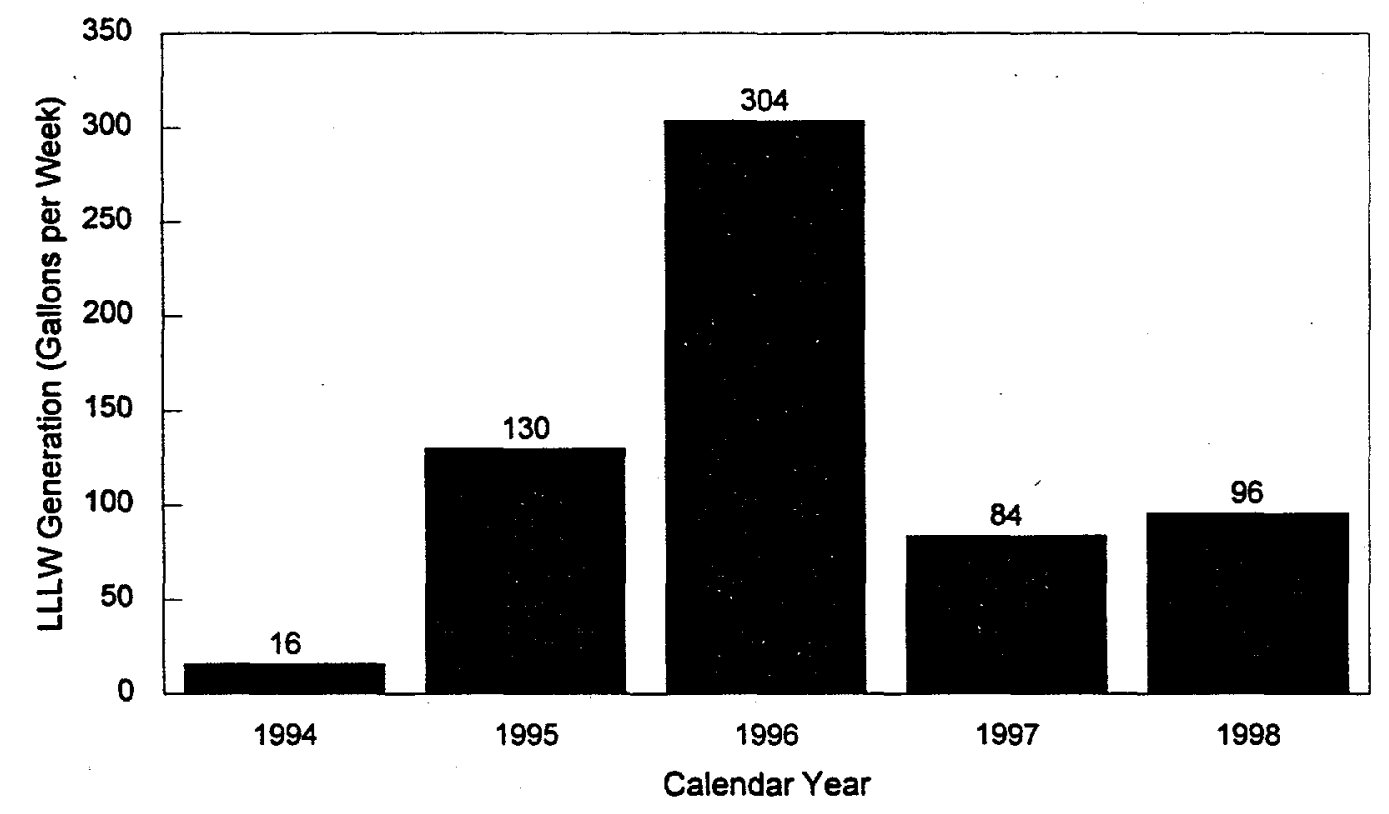

Figure 14. Building 2026 LLLW generation. (ORNL-DWG. 97-5457R2) 


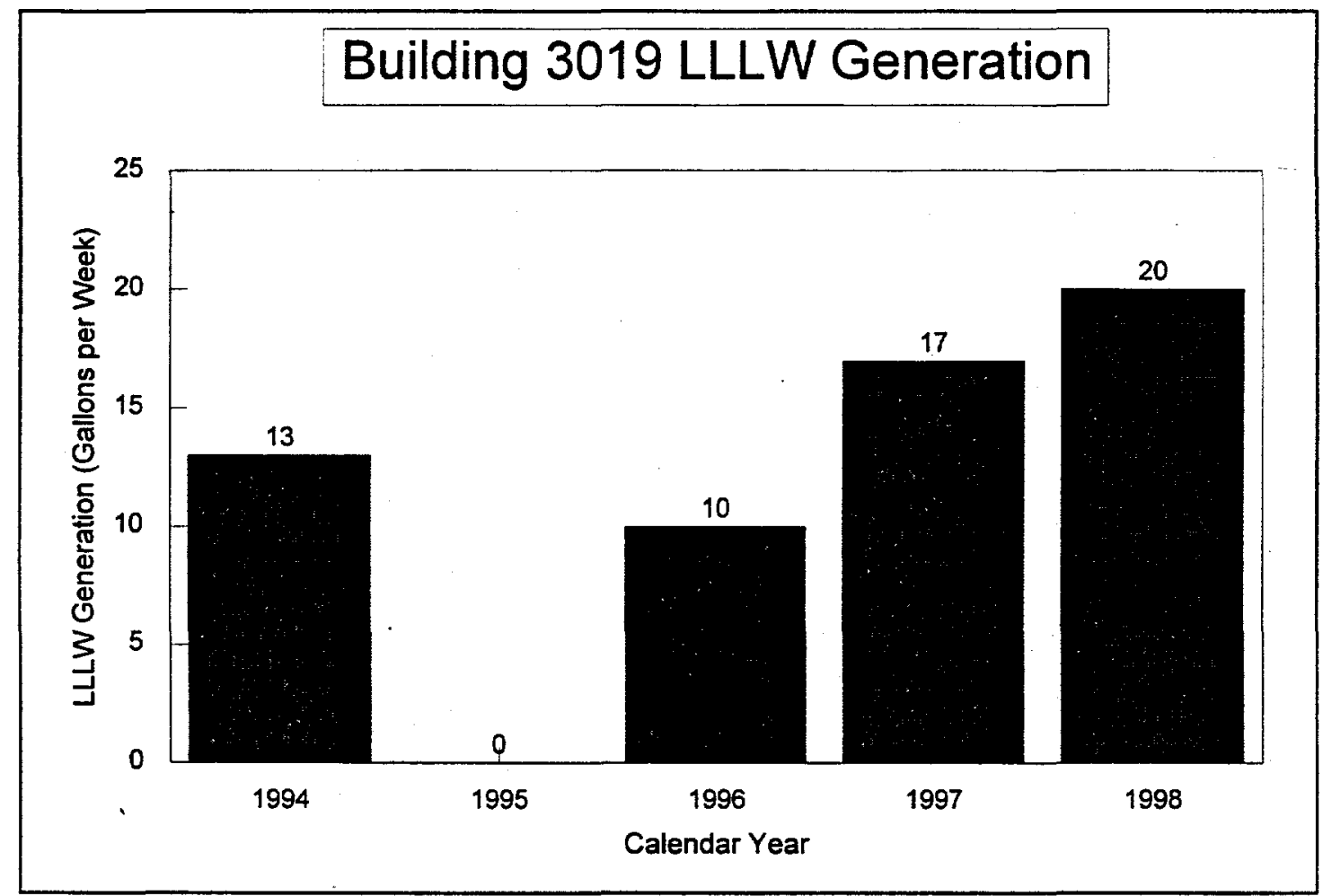

Figure 15. Building 3019 LLLW generation. (ORNL-DWG. 97-5458R2) 


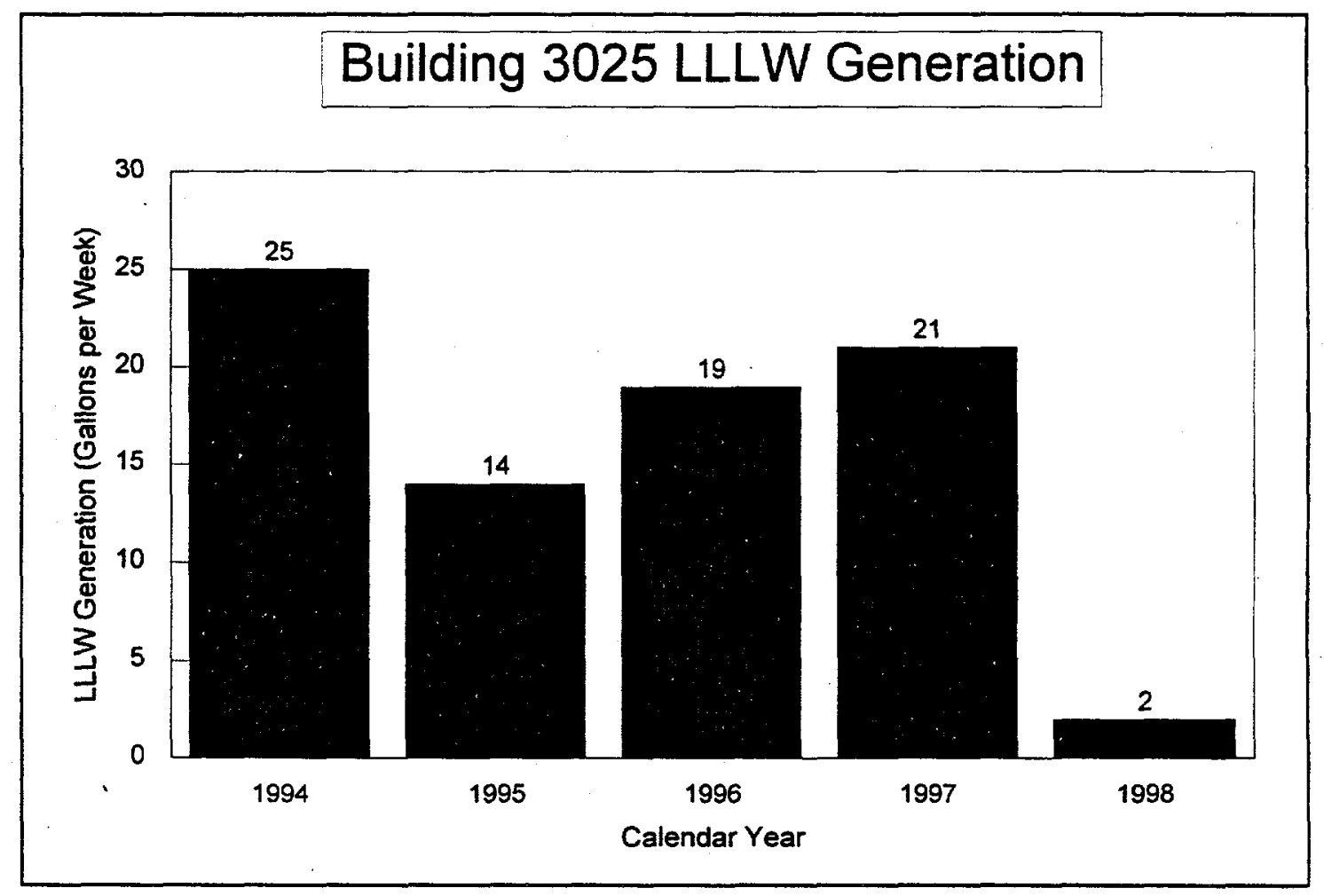

Figure 16. Building 3025 LLLW generation. (ORNL-DWG. 97-5459R2) 


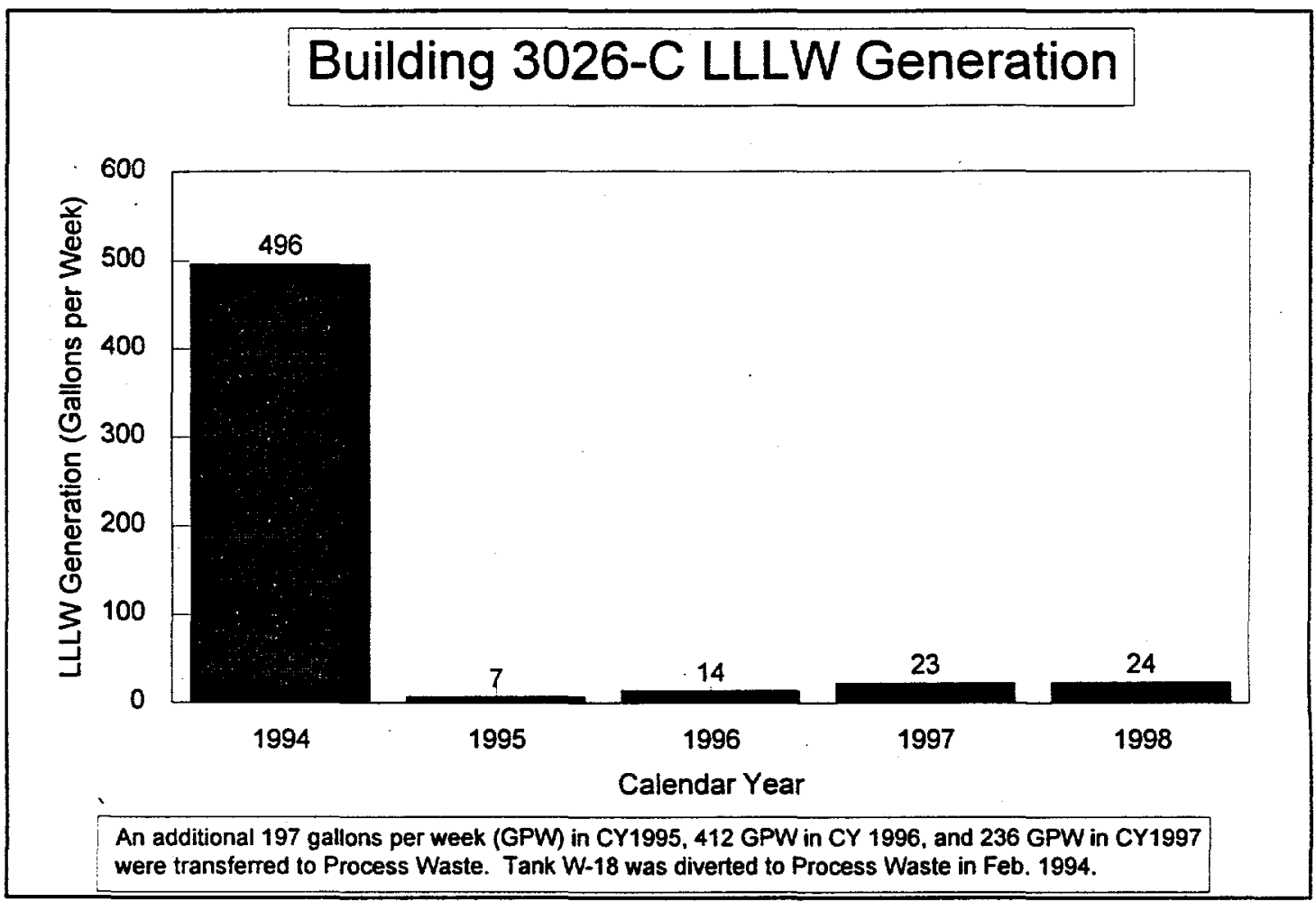

Figure 17. Building 3026-C LLLW generation. (ORNL-DWG. 97-5460R2) 


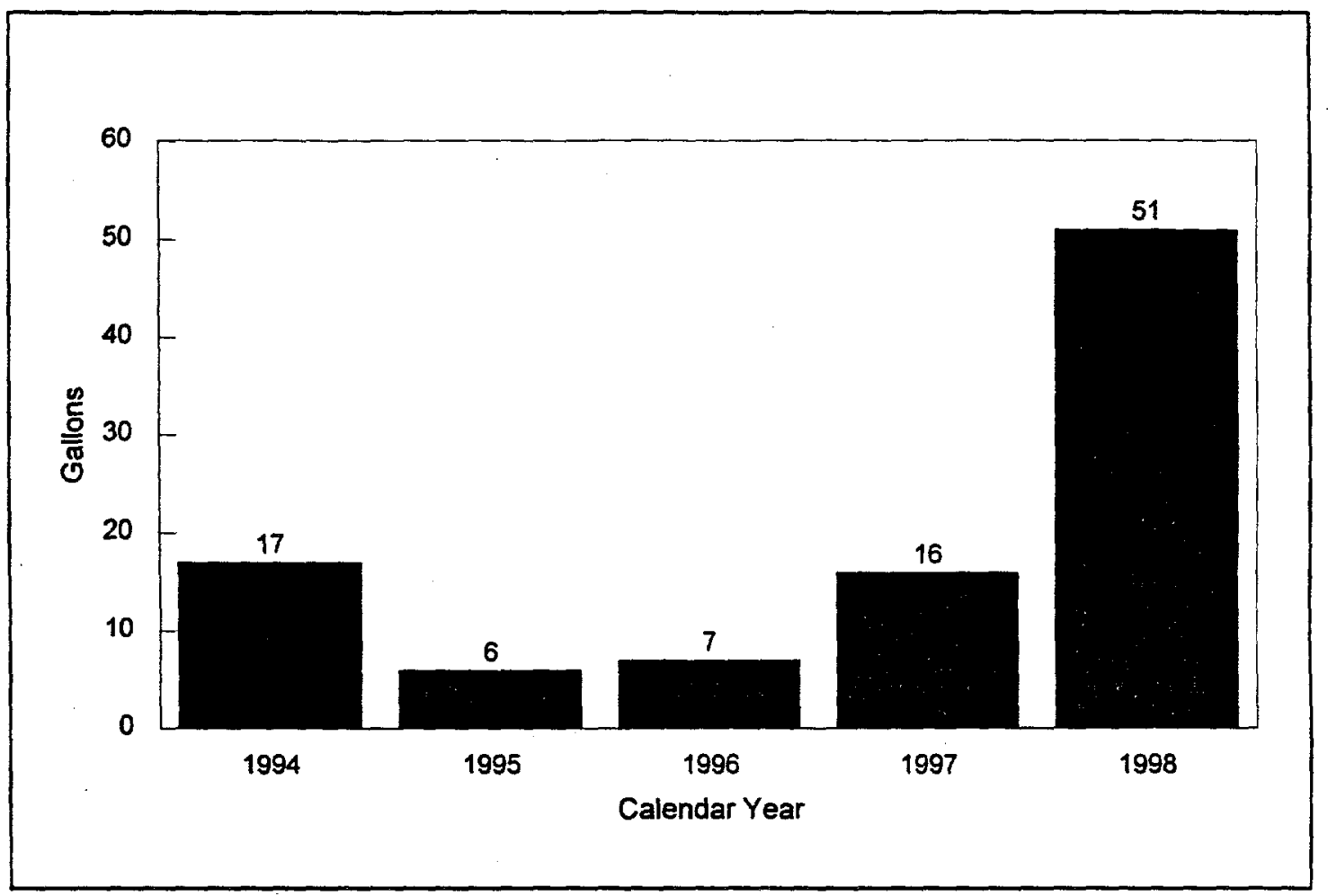

Figure 18. Building 3026-D LLLW generation. (ORNL-DWG. 97-5461R2) 


\section{Stack Area LLLW Generation}

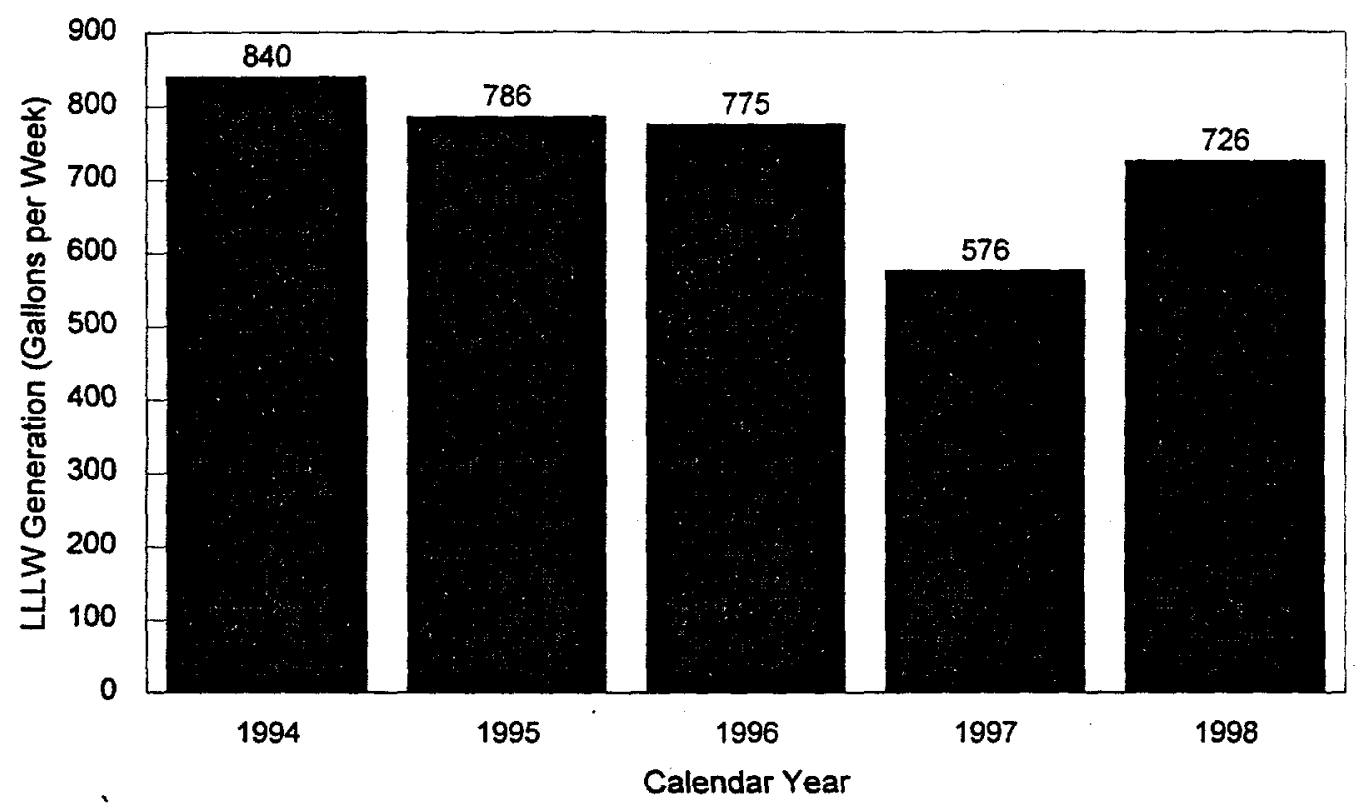

Figure 19. 3039 Stack Area LLLW generation. (ORNL-DWG. 97-5463R2) 


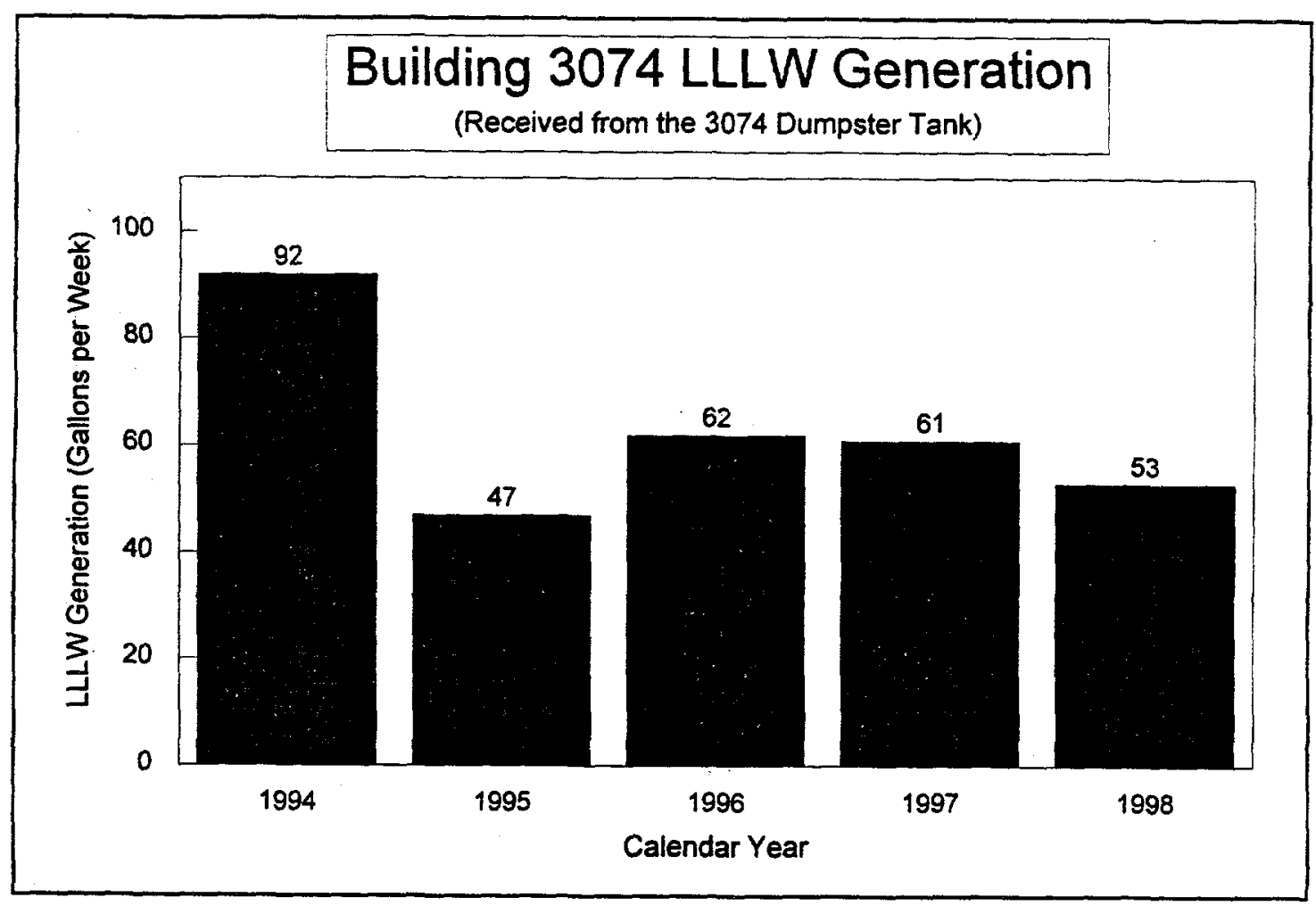

Figure 20. Building 3074 LLLW generation. (ORNL-DWG. 97-5464R2) 


\section{Building 3517 LLLW Generation}

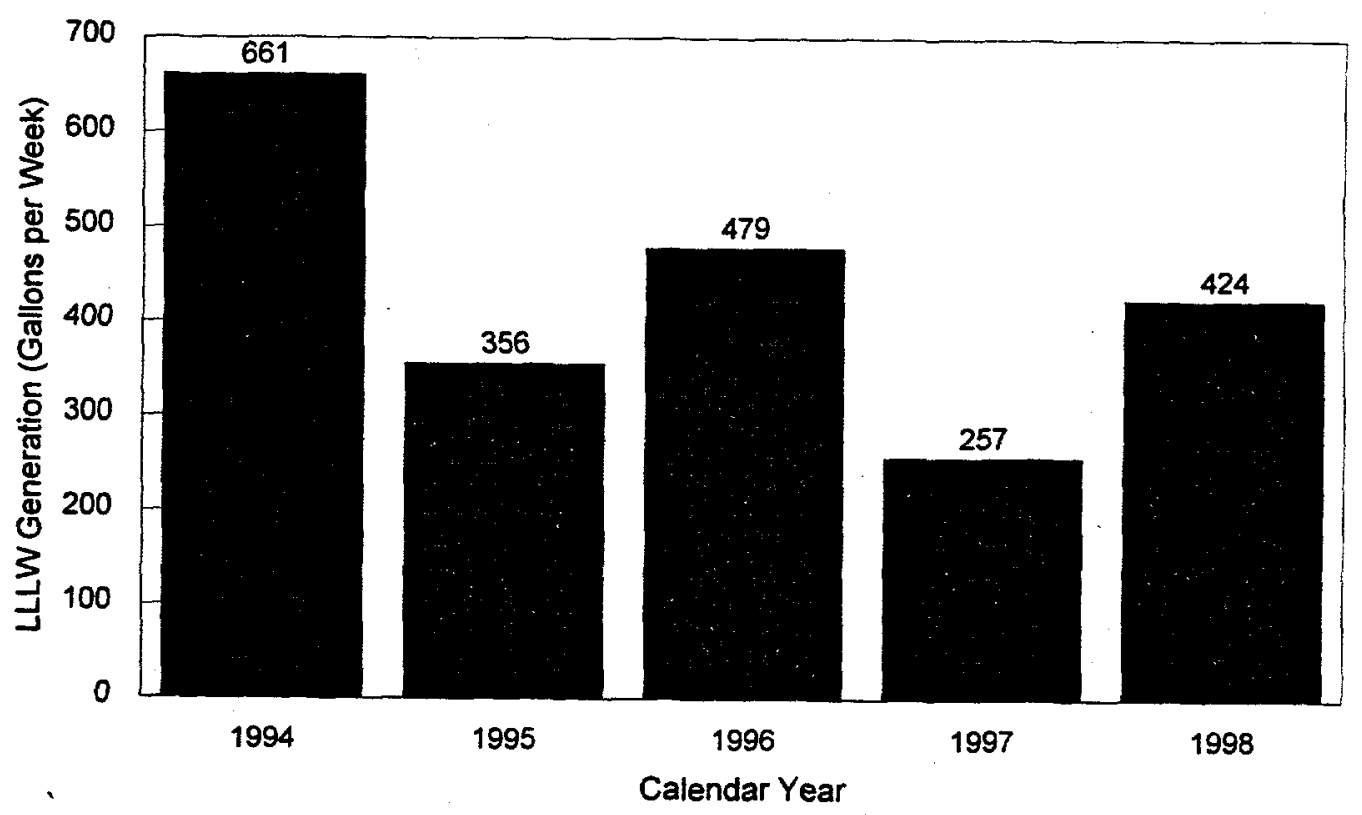

Figure 21. Building 3517 LLLW generation. (ORNL-DWG. 97-5466R2) 


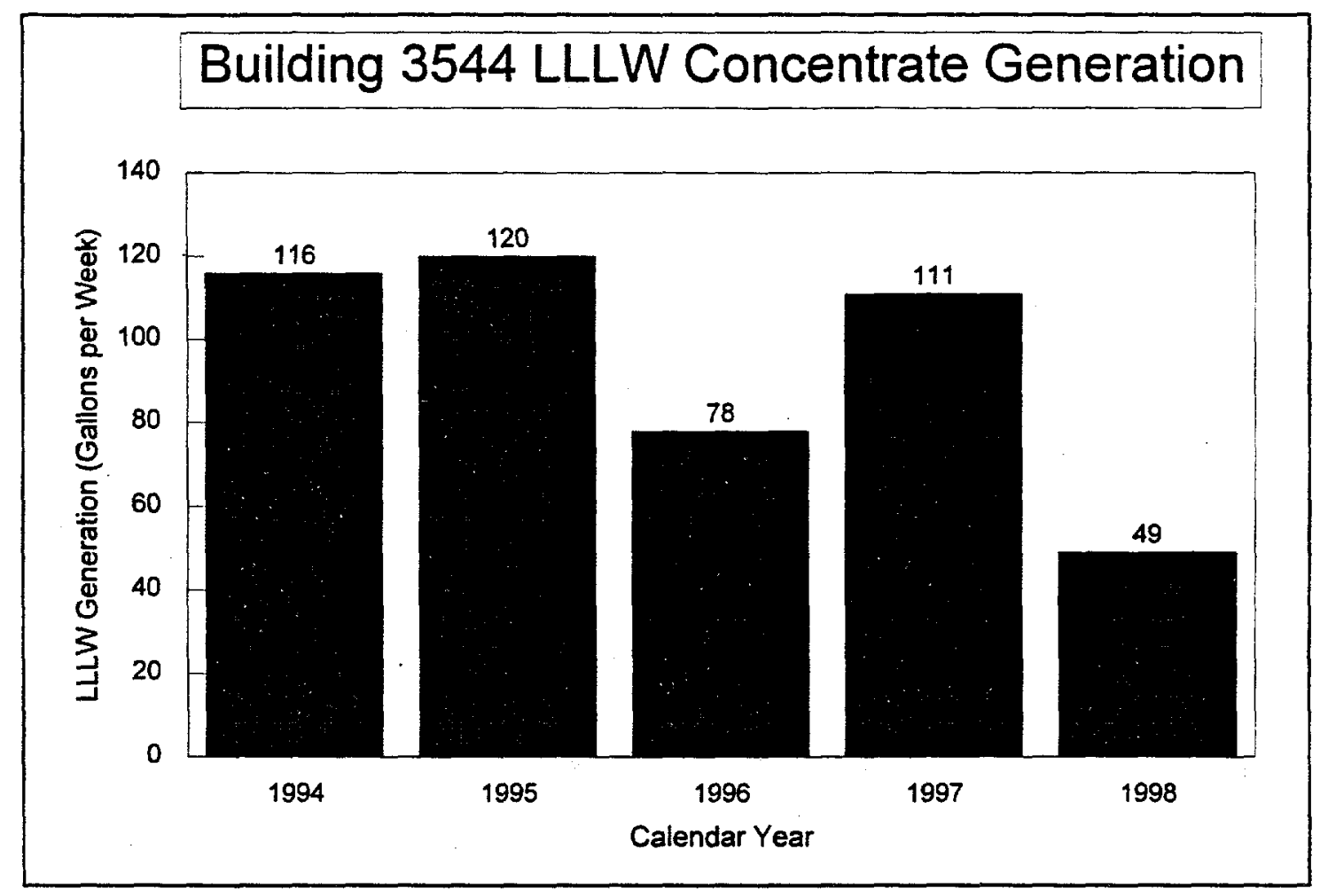

Figure 22. Building 3544 LLLW concentrate generation. (ORNL-DWG. 97-5468R2) 


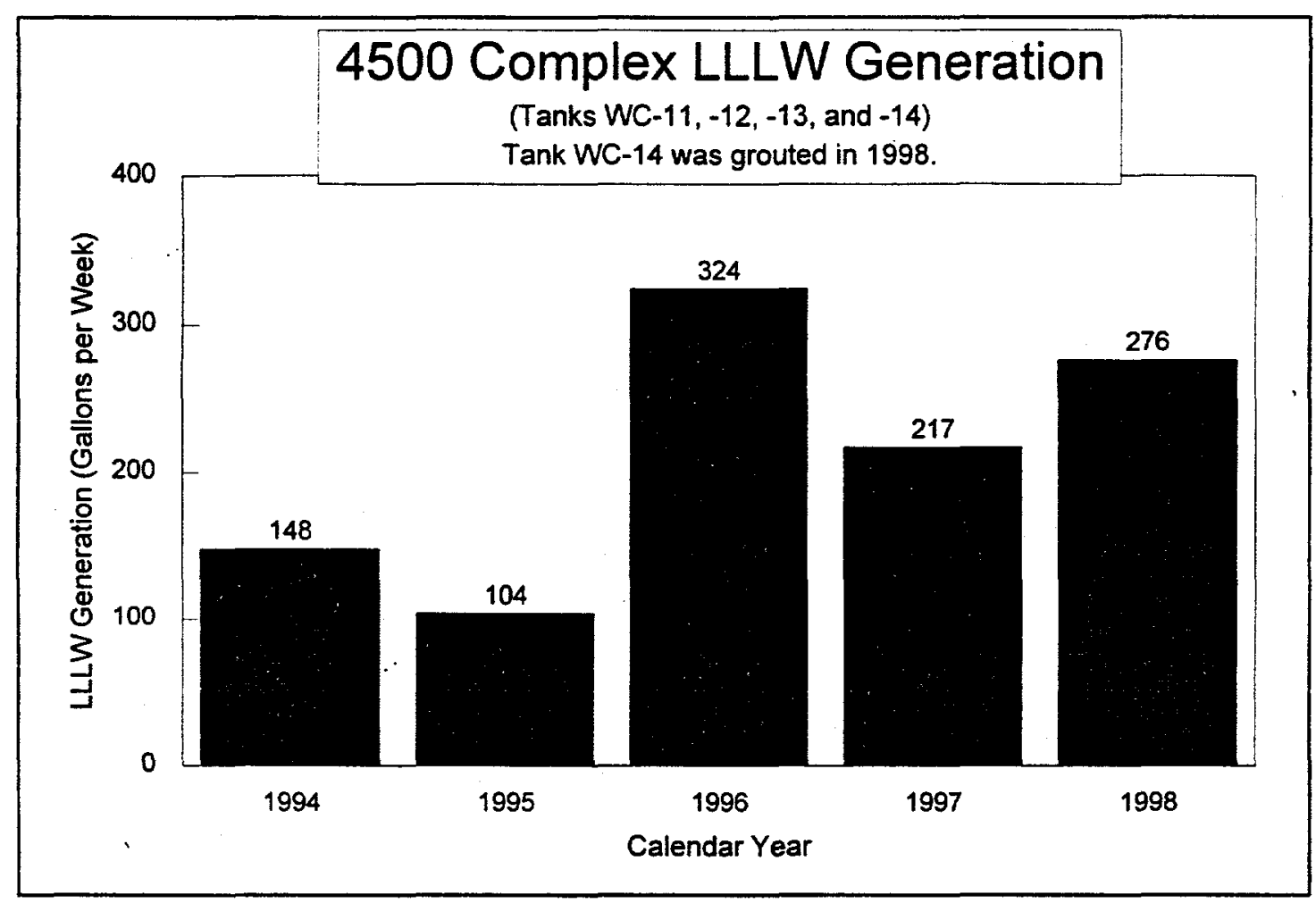

Figure 23. 4500 Complex LLLW generation. (ORNL-DWG. 97-5470R2) 


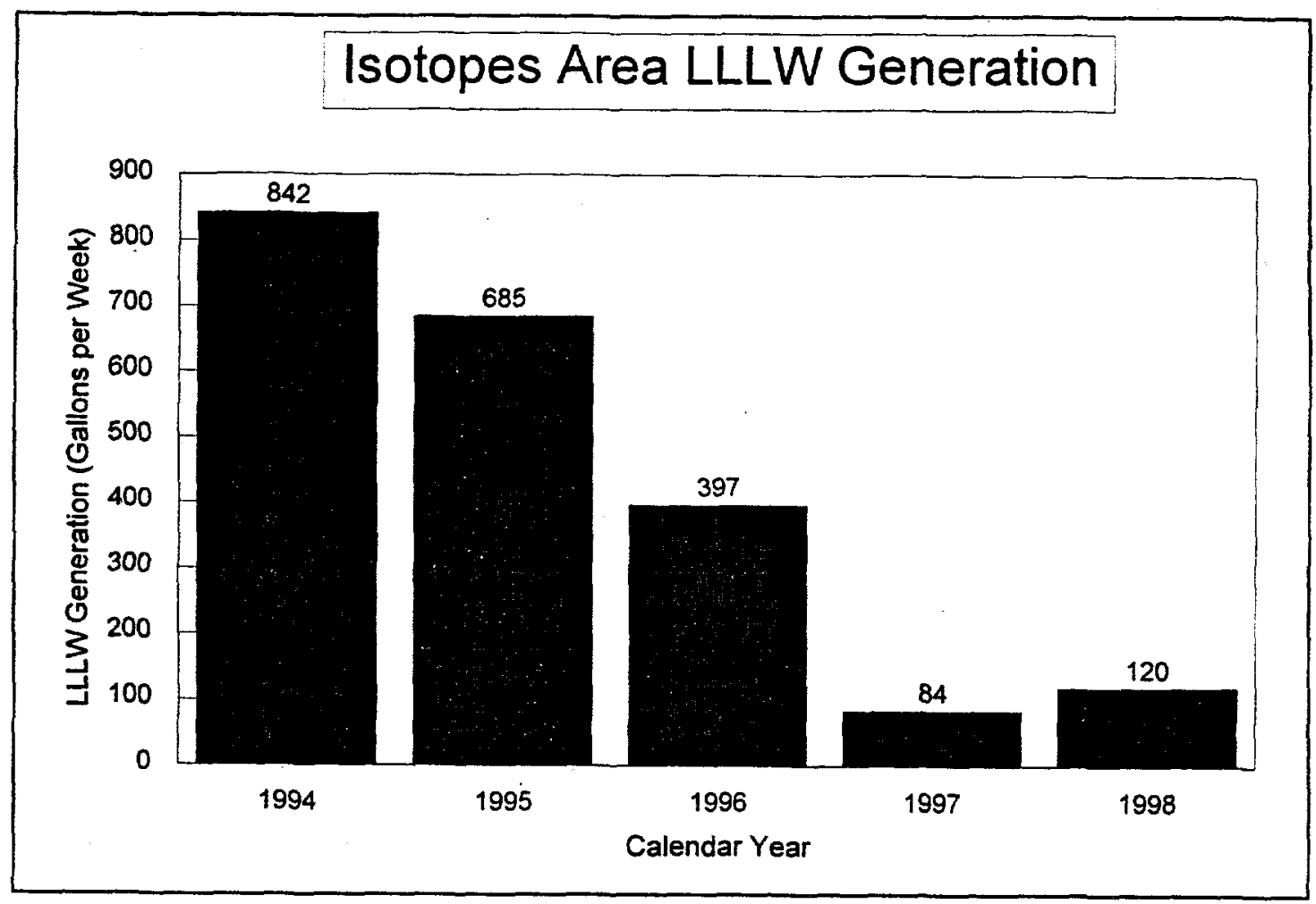

Figure 24. Isotopes Area LLLW generation. (ORNL-DWG. 97-5471R2) 


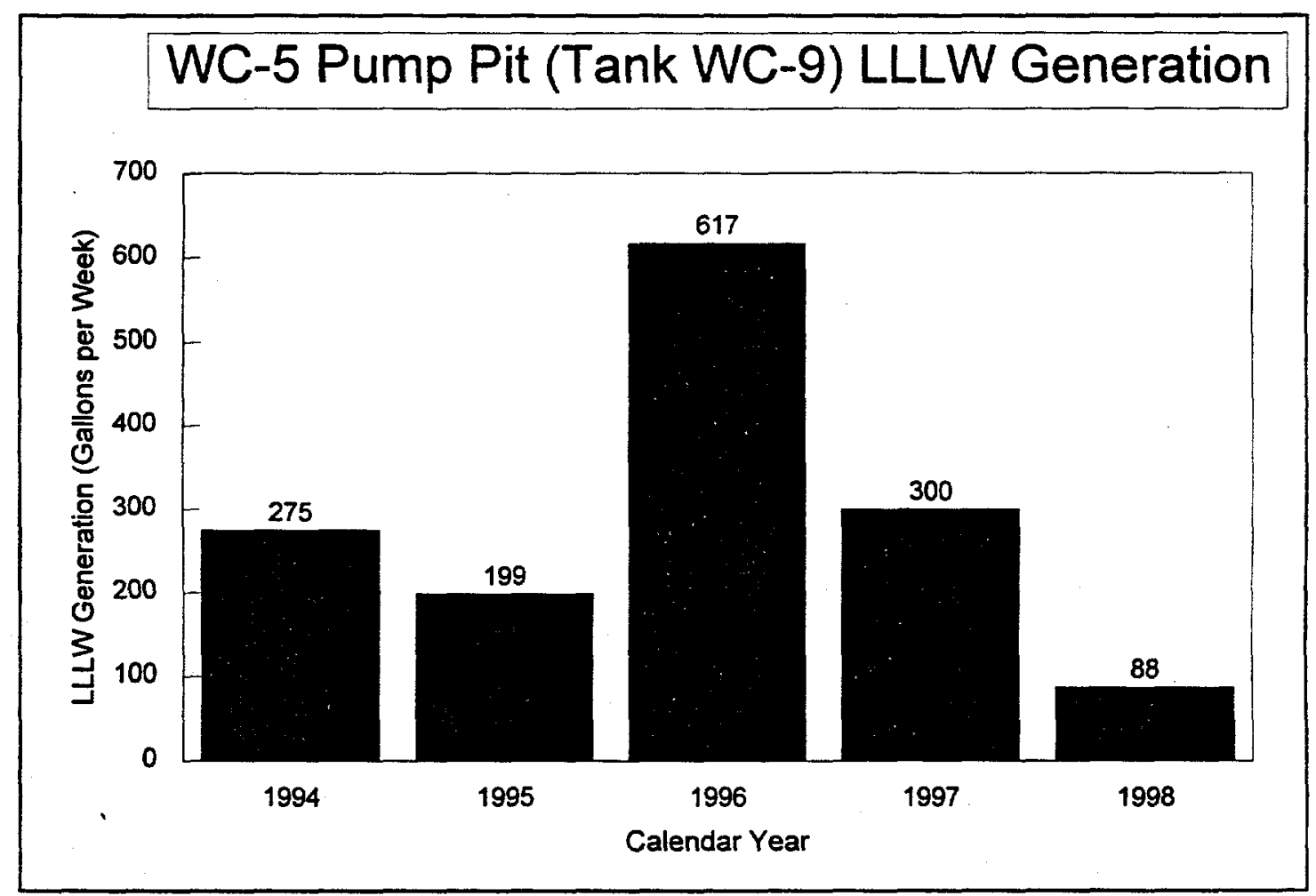

Figure 25. WC-5 Pump Pit (tank WC-9) LLLW generation. (ORNL-DWG. 97-5474R2) 


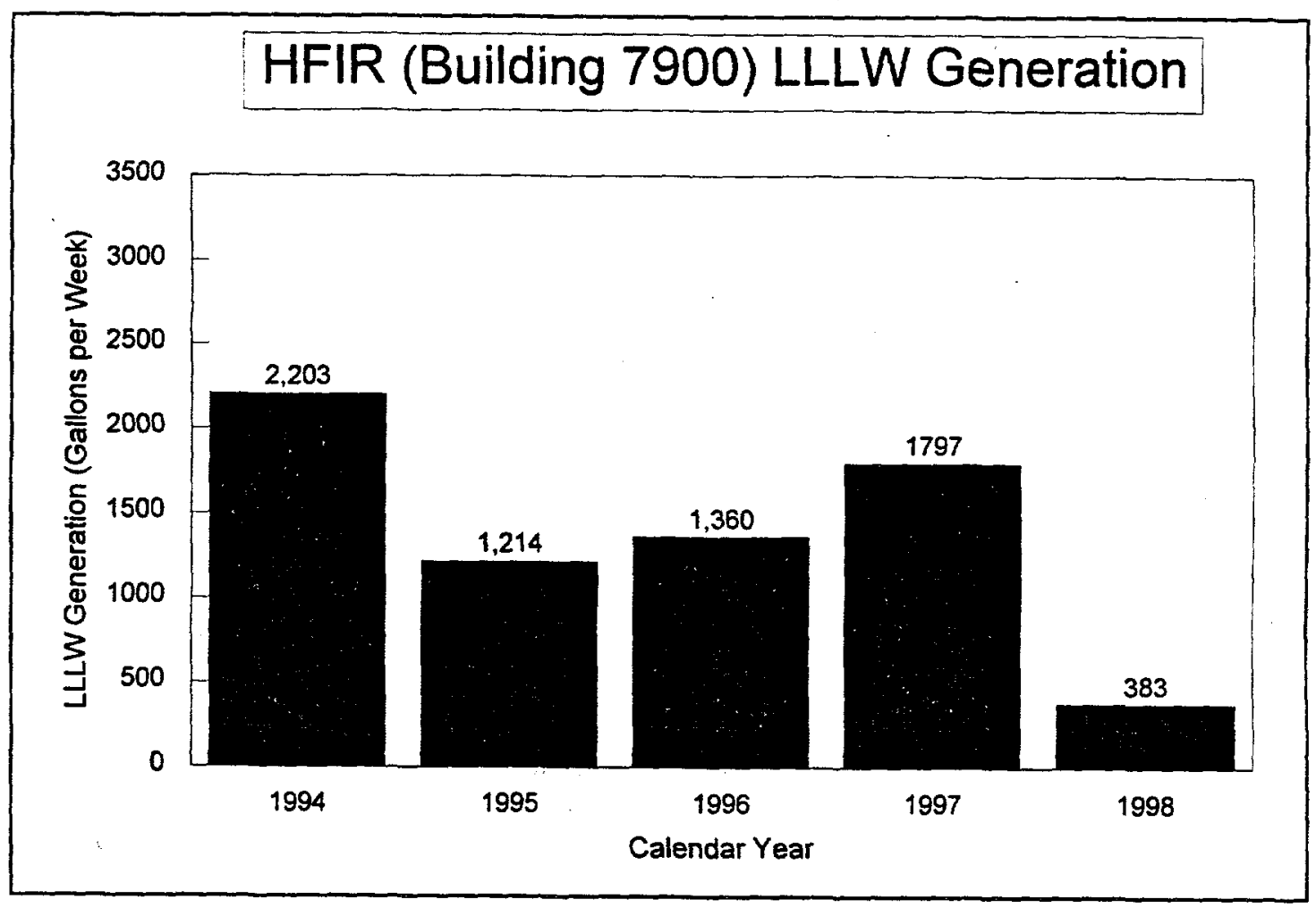

Figure 26. HFIR (Building 7900) LLLW generation. (ORNL-DWG. 97-5475R2) 


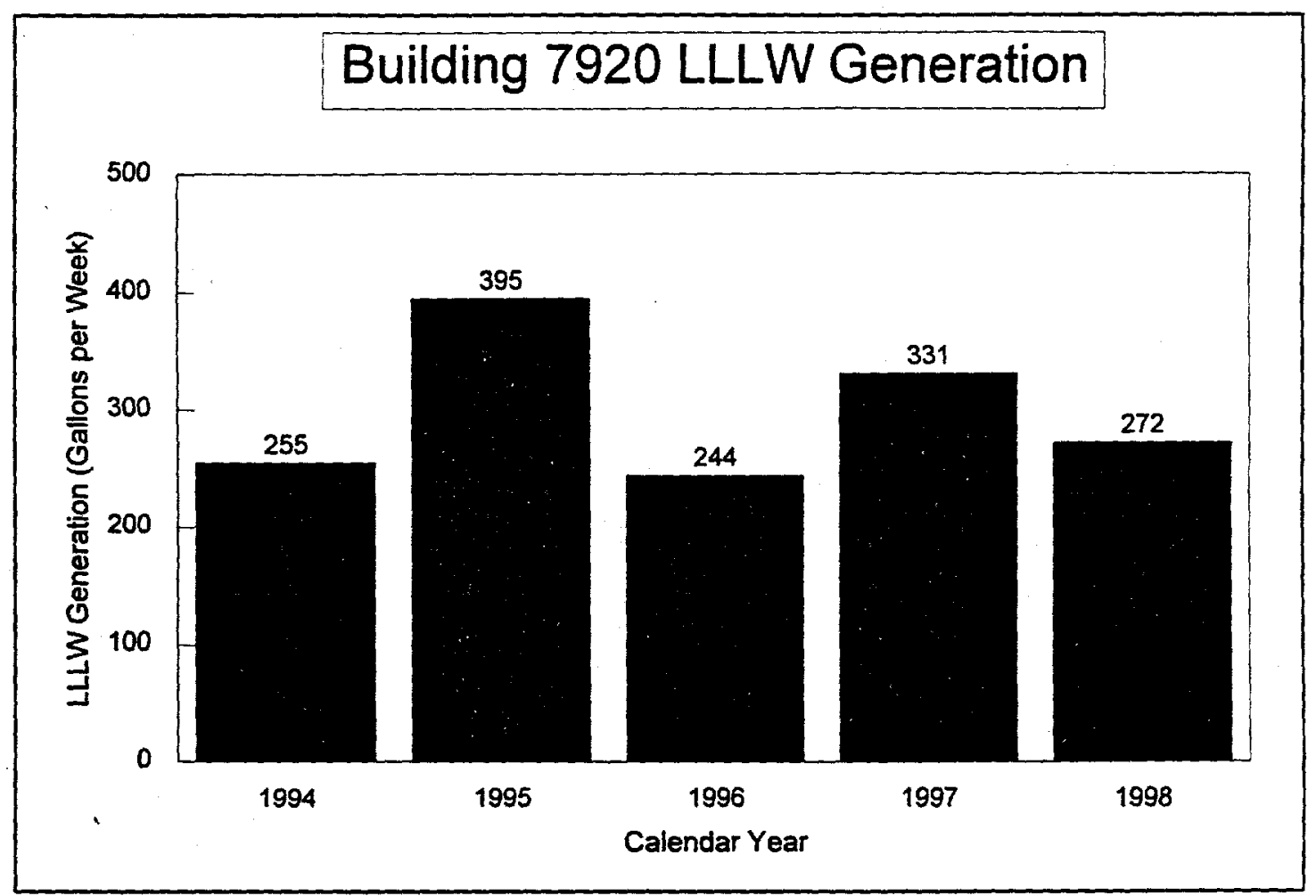

Figure 27. Building 7920 LLLW generation. (ORNL-DWG. 97-5476R2) 


\section{Abandoned Tank W-1A LLLW Generation}

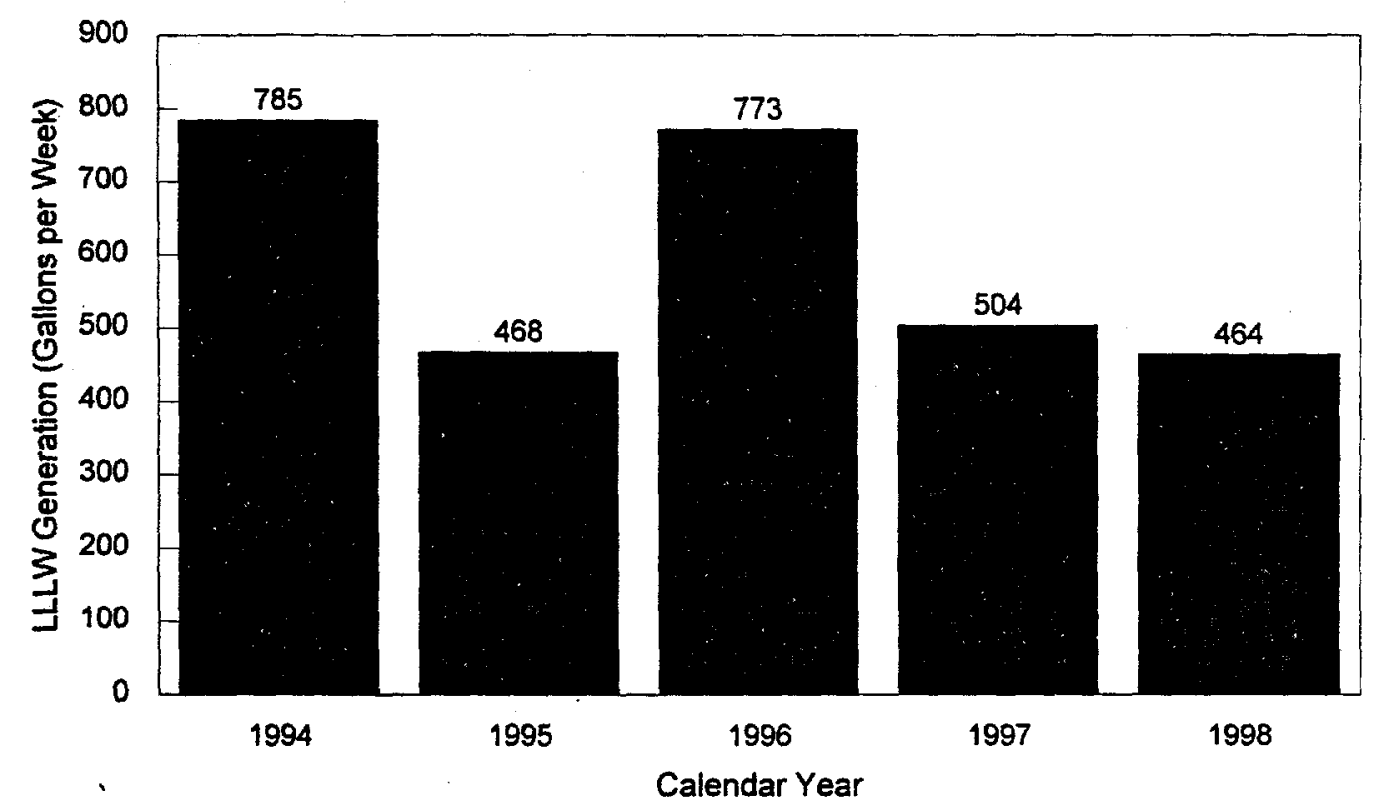

Figure 28. Abandoned tank W-1A LLLW generation. (ORNL-DWG. 97-5477R2) 


\section{STACK CELL VENTILATION SYSTEM}

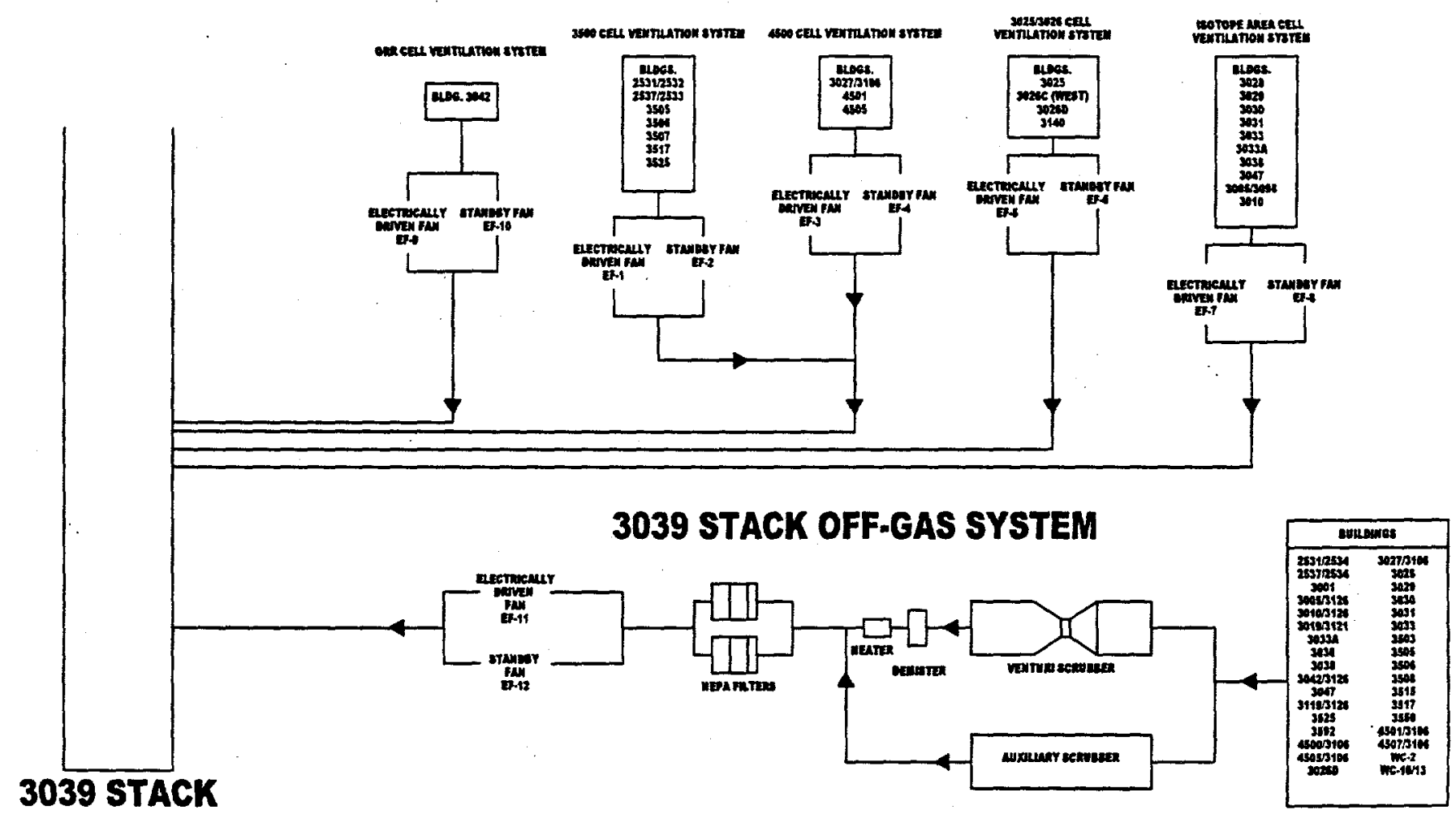

Figure 29. Diagram of the Gaseous Waste System. (ORNL-DWG. 96-3528) 


\section{INTERNAL DISTRIBUTION}

$\begin{aligned} 1 . & \text { S. M. DePaoli } \\ 2 . & \text { C. E. Frye } \\ 3 . & \text { F. R. Hodges } \\ 4 . & \text { T. E. Kent } \\ 5 . & \text { P. S. Kirkham } \\ 6 . & \text { N. A. Langley } \\ 7-9 . & \text { J. J. Maddox } \\ 10 . & \text { T. H. Monk } \\ 11 . & \text { T. E. Myrick } \\ 12 . & \text { B. D. Oakley } \\ 13 . & \text { R. C. Orrin } \\ 14 . & \text { D. J. Peterson } \\ 15 . & \text { J. H. Platfoot } \\ 16 . & \text { S. M. Robinson } \\ 17 . & \text { S. T. Rudell } \\ 18 . & \text { M. A. Smith } \\ 19-21 . & \text { C. B. Scott } \\ 22 . & \text { L. R. Simmons } \\ 23 . & \text { H. Tilford } \\ 24 . & \text { LGWO Documentation Management Center } \\ 25 . & \text { ORNL Central Research Library } \\ 26 . & \text { Y-12 Technical Library } \\ 27-28 . & \text { Laboratory Records Department } \\ 29 . & \text { Laboratory Records - RC }\end{aligned}$

\section{EXTERNAL DISTRIBUTION}

30. C. Pilj, U. S. Department of Energy, Oak Ridge Operations, Federal Building, Oak Ridge, TN 37831

31. Office of Assistant Manager, Energy Research and Development, DOE-ORO, Oak Ridge, TN 37831

32-33. Office of Scientific and Technical Information, P. O. Box 62, Oak Ridge, TN 37830 